\title{
Environmental Setting, Water Budget, and Stream Assessment for the Broad Run Watershed, Chester County, Pennsylvania
}

By Peter J. Cinotto, Andrew G. Reif, and Leif E. Olson

In cooperation with the

Chester County Water Resources Authority, the

Chester County Health Department, and

West Bradford Township, Pennsylvania

Scientific Investigations Report 2005-5156

U.S. Department of the Interior

U.S. Geological Survey 


\title{
U.S. Department of the Interior Gale A. Norton, Secretary
}

\author{
U.S. Geological Survey \\ P. Patrick Leahy, Acting Director
}

\section{U.S. Geological Survey, Reston, Virginia: 2005}

For sale by U.S. Geological Survey, Information Services

Box 25286, Denver Federal Center

Denver, CO 80225

For more information about the USGS and its products:

Telephone: 1-888-ASK-USGS

World Wide Web: http://www.usgs.gov/

Any use of trade, product, or firm names in this publication is for descriptive purposes only and does not imply endorsement by the U.S. Government.

Although this report is in the public domain, permission must be secured from the individual copyright owners to reproduce any copyrighted materials contained within this report.

Suggested citation: Cinotto, P.J., Reif, A.G., and Olson, L.E., 2005, Environmental setting, water budget, and stream assessment for the Broad Run Watershed, Chester County, Pennsylvania: U.S. Geological Survey Scientific Investigations Report 2005-5156, 59 p. 


\section{Contents}

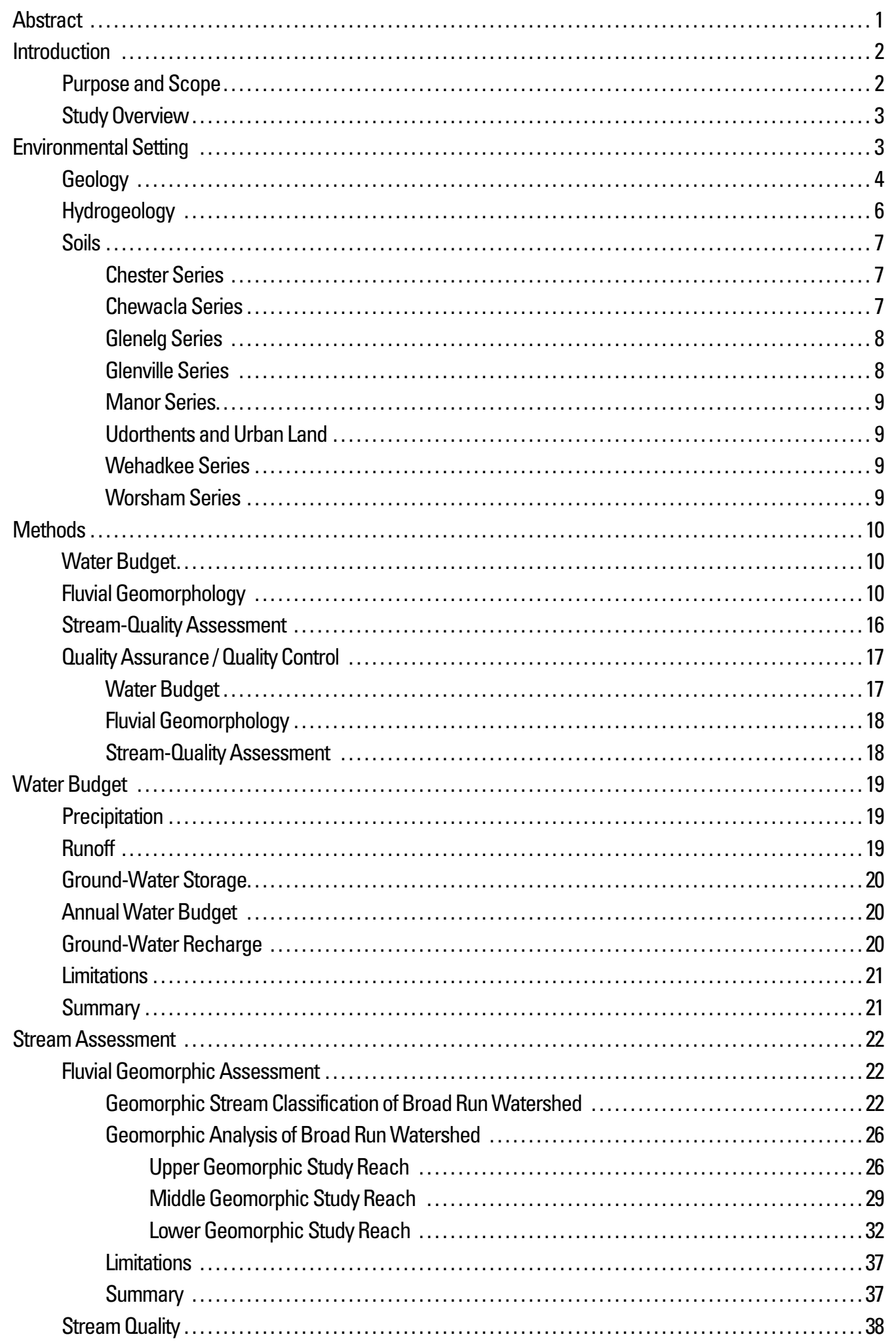




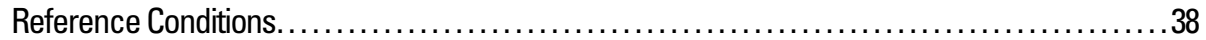

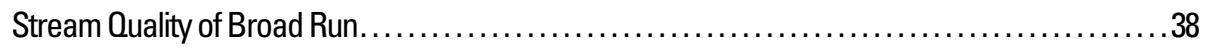

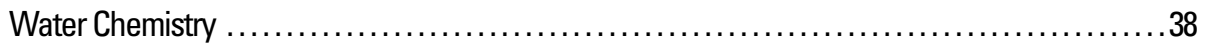

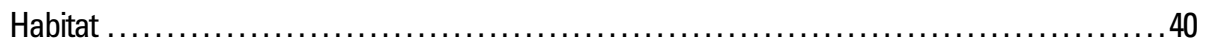

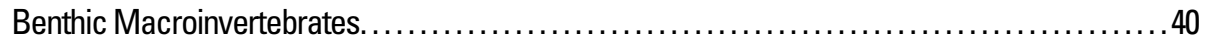

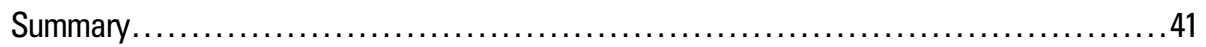

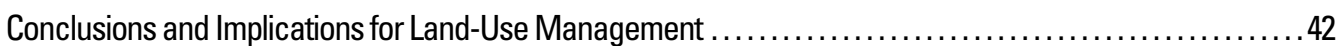

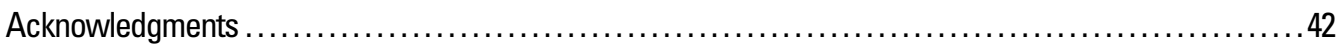

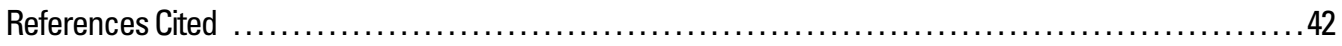

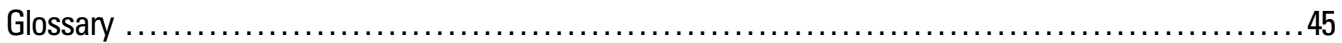

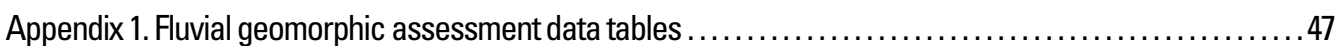

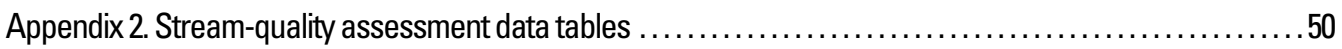

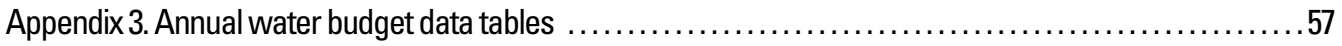

\section{Figures}

1. Map showing location of the Broad Run watershed study area, Chester County, southeastern Pennsylvania.....................................................

2. Graph showing land-use percentages within the Broad Run watershed, Chester County,

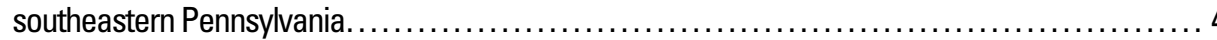

3. Map showing geologic formations and selected hydrologic features within the Broad Run watershed, Chester County, southeastern Pennsylvania .......................... 5

4. Map showing soil-series percentages within the Broad Run watershed, Chester County,

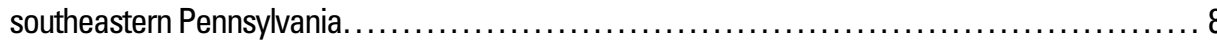

5. Map showing locations of ground-water observation wells, recording precipitation gages, and streamflow-gaging station within the Broad Run watershed, Chester County, southeastern Pennsylvania

6. Photographic view of USGS streamflow-gaging station 01480638 showing recording precipitation gage with solar panel, gage shelter, and crest-stage gage

7-12. Photographs showing:

7. USGS personnel surveying cross section on Broad Run, Chester County, southeastern

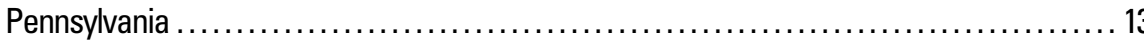

8. USGS personnel collecting global positioning system data on Broad Run, Chester



9. USGS technician making a pebble count, Chester County, southeastern Pennsylvania... . . . 14

10. USGS technician collecting core sample, Chester County, southeastern Pennsylvania. .... 14

11. USGS biologist measuring water chemistry of Broad Run, Chester County, southeastern



12. USGS biologist collecting benthic-macroinvertebrate sample from Broad Run, Chester County, southeastern Pennsylvania. ....................................... 17

13. Map showing Broad Run and tributaries delineated by stream class (Rosgen, 1996), Chester



14. Diagram showing potential stream-channel evolutionary scenarios applicable to Broad Run, Chester County, southeastern Pennsylvania 
15-19. Photographs showing:

15. C-class stream channel approximately 100 feet upstream of head cut and resultant G-class stream channel on unnamed tributary to Broad Run, Chester County,

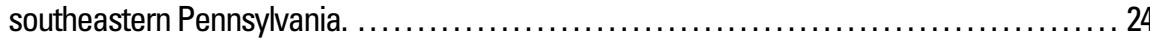

16. Head cut and resultant G-class stream channel on unnamed tributary to Broad Run,

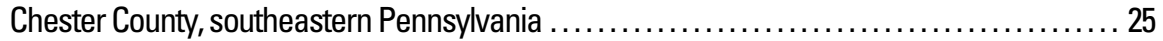

17. Sediment partially resulting from erosion of unnamed tributary to Broad Run filling stormwater-detention basin, Chester County, southeastern Pennsylvania................ 25

18. Beaver dam on Broad Run, Chester County, southeastern Pennsylvania ................ 25

19. Beaver-felled trees in wetland on Broad Run, Chester County, southeastern Pennsylvania. . 26

20. Map showing locations of geomorphic study reaches within the Broad Run watershed, Chester County, southeastern Pennsylvania. 27

21. Map showing upper geomorphic study reach on Broad Run, Chester County, southeastern

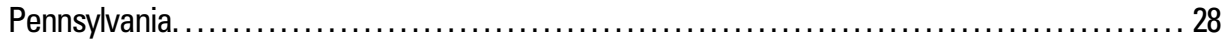

22. Photograph showing representative view looking downstream at upper geomorphic study reach on Broad Run, Chester County, southeastern Pennsylvania ..... 29

23. Map showing middle geomorphic study reach on Broad Run, Chester County, southeastern Pennsylvania. ....

24-26. Photographs showing:

24. Representative view looking downstream at middle geomorphic study reach on Broad Run, Chester County, southeastern Pennsylvania. .... 31

25. View of left bank and available floodplain, middle geomorphic study reach on Broad Run, Chester County, southeastern Pennsylvania .............................. 31

26. View looking downstream at scour hole in streambed of middle geomorphic study reach on Broad Run, Chester County, southeastern Pennsylvania ......................... 31

27. Map showing lower geomorphic study reach on Broad Run, Chester County, southeastern Pennsylvania

28-30. Photographs showing:

28. View looking upstream, approximately 100 feet downstream from cross-section 311, on lower geomorphic study reach, Broad Run, Chester County, southeastern Pennsylvania.

29. View looking downstream at cross-section 616, just above Northbrook Road, on lower geomorphic study reach, Broad Run, Chester County, southeastern Pennsylvania. ... 34

30. View looking toward right bank, with large evulsion, on lower geomorphic study reach of Broad Run, Chester County, southeastern Pennsylvania. ...

31. Graph showing water depth at U.S. Geological Survey streamflow-gaging station 01480638 (Broad Run at Northbrook), Chester County, southeastern Pennsylvania, April 1, 2003 to March 31, 2004, showing depth of initial flooding and depth at which downstream box culvert is at full capacity. ....

32. Graph showing flow-duration curves for Broad Run and several other regional streams, Chester County, southeastern Pennsylvania.

33. Map showing location of U.S. Geological Survey streamflow-gaging stations used for comparison of flow-duration curves, Chester County, southeastern Pennsylvania.

34. Map showing locations of biologic study sites within the Broad Run watershed, Chester County, southeastern Pennsylvania..... 


\section{Tables}

1. Detailed descriptions of the geologic formations within the Broad Run watershed, Chester

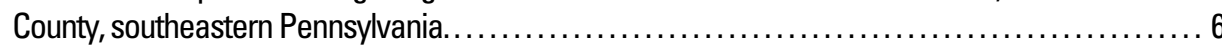

2. Geomorphic data categories used in delineation of stream classes within the Broad Run watershed, Chester County, southeastern Pennsylvania. .......................... 13

3. Data required for fluvial geomorphic analysis of intensive study sites, Broad Run, Chester County, southeastern Pennsylvania, 2003.

4. Required data for use in fluvial geomorphic stability calculations at intensive study sites, Broad Run, Chester County, southeastern Pennsylvania, 2003............................ 15

5. Parameters and associated equations for the determination of dimensionless critical shear stress, Broad Run, Chester County, southeastern Pennsylvania, 2003.................... 15

6. Shields parameter classifications used for fluvial geomorphic assessment of Broad Run, Chester County, southeastern Pennsylvania, 2003. ................................... 16

7. Estimated monthly direct-runoff and base-flow components of the total streamflow in the Broad Run watershed, April 2003 to March 2003, Chester County, southeastern Pennsylvania........... 20

8. Summary of the annual water budget components determined for the Broad Run watershed, April 2003 to March 2003, Chester County, southeastern Pennsylvania. ................... 21

9. Summary of total taxa; Ephemeroptera, Plecoptera, and Trichoptera (EPT) taxa richness; and Hilsenhoff Biotic Index (HBI) values for benthic-macroinvertebrates samples collected from Broad Run, Chester County, Pa., 1999-2002. 


\section{Conversion Factors and Datum}

\begin{tabular}{|c|c|c|}
\hline Multiply & By & To obtain \\
\hline \multicolumn{3}{|c|}{ Length } \\
\hline inch (in.) & 25.4 & millimeter (mm) \\
\hline foot (ft) & 0.3048 & meter $(\mathrm{m})$ \\
\hline \multicolumn{3}{|c|}{ Area } \\
\hline acre & 4,047 & square meter $\left(\mathrm{m}^{2}\right)$ \\
\hline square foot $\left(\mathrm{ft}^{2}\right)$ & 0.09290 & square meter $\left(\mathrm{m}^{2}\right)$ \\
\hline square mile $\left(\mathrm{mi}^{2}\right)$ & 2.590 & square kilometer $\left(\mathrm{km}^{2}\right)$ \\
\hline \multicolumn{3}{|c|}{ Volume } \\
\hline million gallons (Mgal) & 3,785 & cubic meter $\left(\mathrm{m}^{3}\right)$ \\
\hline \multicolumn{3}{|c|}{ Density } \\
\hline pound per cubic foot $\left(\mathrm{lb} / \mathrm{ft}^{3}\right)$ & 16.02 & kilogram per cubic meter \\
\hline \multicolumn{3}{|c|}{ Flow rate } \\
\hline cubic foot per second $\left(\mathrm{ft}^{3} / \mathrm{s}\right)$ & 0.02832 & cubic meter per second $\left(\mathrm{m}^{3} / \mathrm{s}\right)$ \\
\hline $\begin{array}{l}\text { million gallons per day per square mile } \\
{\left[(\mathrm{Mgal} / \mathrm{d}) / \mathrm{mi}^{2}\right]}\end{array}$ & 1,461 & $\begin{array}{l}\text { cubic meter per day per square kilo- } \\
\text { meter }\left[\left(\mathrm{m}^{3} / \mathrm{d}\right) / \mathrm{km}^{2}\right]\end{array}$ \\
\hline \multicolumn{3}{|c|}{ Mass } \\
\hline pound, avoirdupois (lb) & 0.4536 & kilogram $(\mathrm{kg})$ \\
\hline
\end{tabular}

Temperature in degrees Celsius $\left({ }^{\circ} \mathrm{C}\right)$ may be converted to degrees Fahrenheit $\left({ }^{\circ} \mathrm{F}\right)$ as follows:

${ }^{\circ} \mathrm{F}=\left(1.8 \mathrm{x}^{\circ} \mathrm{C}\right)+32$

Temperature in degrees Fahrenheit $\left({ }^{\circ} \mathrm{F}\right)$ may be converted to degrees Celsius $\left({ }^{\circ} \mathrm{C}\right)$ as follows:

${ }^{\circ} \mathrm{C}=\left({ }^{\circ} \mathrm{F}-32\right) / 1.8$

Vertical coordinate information is referenced to the North American Vertical Datum of 1988 (NAVD 88).

Horizontal coordinate information is referenced to the North American Datum of 1983 (NAD 83).

Altitude, as used in this report, refers to distance above the vertical datum.

Specific conductance is given in microsiemens per centimeter at 25 degrees Celsius $/ \mu \mathrm{S} / \mathrm{cm}$ at $\left.25^{\circ} \mathrm{C}\right)$.

Concentrations of chemical constituents in water are given either in milligrams per liter $(\mathrm{mg} / \mathrm{L})$ or micrograms per liter $(\mu \mathrm{g} / \mathrm{L})$.

Mesh sizes of sampling devices are given in micrometers $(\mu \mathrm{m}) ; 1,000$ micrometers equal a millimeter (mm). 



\title{
Environmental Setting, Water Budget, and Stream Assessment for the Broad Run Watershed, Chester County, Southeastern Pennsylvania
}

\author{
By Peter J. Cinotto, Andrew J. Reif, and Leif E. Olson
}

\section{Abstract}

The Broad Run watershed lies almost entirely in West Bradford Township, Chester County, Pa., and drains 7.08 square miles to the West Branch Brandywine Creek. Because of the potential effect of encroaching development and other stresses on the Broad Run watershed, West Bradford Township, the Chester County Water Resources Authority, and the Chester County Health Department entered into a cooperative study with the U.S. Geological Survey to complete an annual water budget and stream assessment of overall conditions. The annual water budget quantified the basic parameters of the hydrologic cycle for the climatic conditions present from April 1, 2003, to March 31, 2004. These water-budget data identified immediate needs and (or) deficits that were present within the hydrologic cycle during that period, if present; however, an annual water budget encompassing a single year does not identify long-term trends. The stream assessment was conducted in two parts and assessed the overall condition of the watershed, an overall assessment of the fluvial-geomorphic conditions within the watershed and an overall assessment of the stream-quality conditions. The data collected will document present (2004) conditions and identify potential vulnerabilities to future disturbances.

For the annual period from April 1, 2003, to March 31, 2004 , determination of an annual water budget indicated that of the 67.8 inches of precipitation that fell on the Broad Run watershed, 38.8 inches drained by way of streamflow to the West Branch Brandywine Creek. Of this 38.8 inches of streamflow, local-minimum hydrograph separation techniques determined that 7.30 inches originated from direct runoff and 31.5 inches originated from base flow. The remaining precipitation went into ground-water storage ( 1.71 inches) and was lost to evapotranspiration (27.3 inches). Ground-water recharge for this period-35.2 inches - was based on these values and an estimated ground-water evapotranspiration rate of 2 inches.

Assessment of fluvial-geomorphic conditions included large-scale mapping of stream classes within the Broad Run watershed and in-depth study of three representative stream reaches also within the Broad Run watershed. Based on the total distance of all stream reaches classified within the Broad Run watershed, 61 percent were classified as C-class, 14 percent as E-class, 13 percent as B-class, 5 percent as F-class, 4 percent as undifferentiated B- and F-class, 2 percent as G-class, and less than 1 percent as A-class. The map of stream classes indicates that the Broad Run watershed currently has no large-scale areas of stream impairment and that, generally, the stream is not entrenched and the main branch of the Broad Run has an available, functioning flood plain. Smaller tributary streams, however, showed signs of localized entrenchment due to site-specific influences such as natural stream-channel evolution, localized channelization, localized contraction due to road and driveway crossings, and (or) increased localized runoff. For example, one small reach along a tributary channel was observed to become entrenched due to runoff originating from a new housing development. Entrenched stream reaches are merely located by large-scale mapping and require individual assessment to determine potential causes of entrenchment and (or) future restorative actions. Three in-depth geomorphic study sites showed that the Broad Run can currently be considered graded or in a state of dynamic equilibrium. The sites did, however, identify certain vulnerabilities to future changes within the watershed. These vulnerabilities included disruption of the present sediment supply, including both increases and (or) reductions in the current sediment loads within the Broad Run; increases in both magnitude and duration of storm-water runoff; encroachment of development onto present flood-plain areas, and (or) alterations to riparian zones.

Assessment of stream-quality conditions included an assessment of the in-stream habitat, biologic health, and water quality within the watershed. In-stream habitat assessments indicated good overall habitat throughout the Broad Run watershed. Biologic samples collected indicated diverse and healthy benthic-macroinvertebrate communities that included many pollution-intolerant species. Water-quality samples showed that nutrient, ion, and metal concentrations are all similar to conditions present at a nearby reference site. 


\section{Environmental Setting, Water Budget, and Stream Assessment for the Broad Run Watershed, Chester County, Pa.}

\section{Introduction}

The 7.08- $\mathrm{mi}^{2}$ Broad Run watershed is within Chester County, $\mathrm{Pa}$,; most (approximately 98.5 percent) is in West Bradford Township, and the remainder (approximately 1.5 percent or $0.08 \mathrm{mi}^{2}$ ) is in Newlin Township (fig. 1). Because so much of the watershed is in West Bradford Township, changes in land cover and land use within the township can substantially affect the watershed.

This region and the Broad Run watershed have a long history of such change. According to West Bradford Township (2004), the township was originally part of Bradford Township as organized in 1705; West Bradford Township was officially formed in 1731 when the original Bradford Township was split into west and east sections. About this time, the first European settlers moved into the Broad Run watershed and began farming the valleys. Agriculture remained the primary land use within the region for the next century, but it was largely confined to the valley bottoms; forests dominated the surrounding steep hillsides. In the early 1800 s, improvements in the road system brought the first signs of development to the region. The towns of Marshallton and Romansville began to grow, and local businesses were established. Numerous tanning, grist, saw, and fulling mills were located throughout the region and along Broad Run. Various historic farms still operate within the watershed; most of the remaining watershed is dominated by wooded areas, isolated homes, planned residential communities, and a golf course.

Recognizing the changing land uses within the watershed, West Bradford Township, the Chester County Water Resources Authority, and the Chester County Health Department began a cooperative study in 2003 with the U.S. Geological Survey (USGS) to quantify the current (2004) quantity and quality of water in the Broad Run watershed and identify future vulnerabilities. The objectives of this study were to develop a comprehensive tool from which to (1) gage the effects of continued changes within the watershed and (2) provide the data required to assist local, State, and Federal authorities in the development of management and (or) restoration plans for this watershed.

\section{Purpose and Scope}

This purpose of this report is to describe the environmental hydrologic setting, present an annual water budget, characterize the fluvial geomorphology, and characterize the stream-quality conditions for the Broad Run watershed. This study took place from October 1, 2002, to September 30, 2004, and encompassed the entire Broad Run watershed. The water budget and stream assessment consist of an annual water budget (streamflow, precipitation, storage, evapotranspiration, hydrograph separation, and recharge), an assessment of the fluvial geomorphology of Broad Run (stream type, bankfull discharge, bankfull cross-

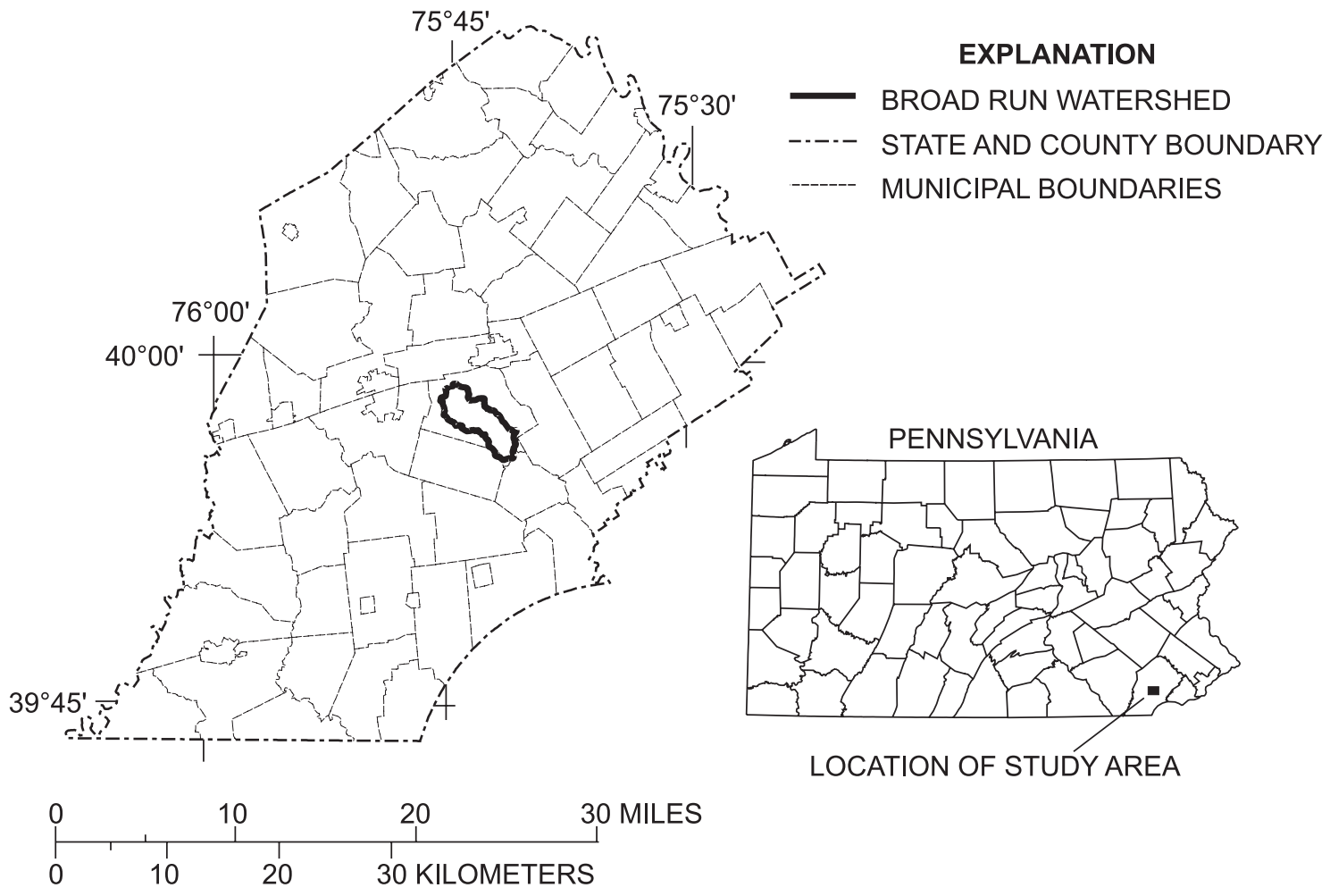

Figure 1. Location of the Broad Run watershed study area, Chester County, southeastern Pennsylvania. 
sectional area, bankfull width, bankfull mean depth, bankfull slope ${ }^{1}$, particle size, and particle entrainment), and an assessment of stream quality of the watershed (benthic-macroinvertebrate diversity, water quality, and habitat quality).

\section{Study Overview}

Three major watershed issues were addressed in this study: annual water budget, fluvial-geomorphic characteristics, and stream quality. These components of the study describe and set a baseline for the hydrologic conditions of the watershed, the capacity of the stream channel to transport the water and sediment supplied from upstream, and the health of aquatic organisms and their habitat within the stream. Current signs of stream habitat degradation, channel instability, and (or) vulnerability to future land-use changes within the watershed are addressed as a part of each study component.

An annual water budget was completed to illustrate where water in the basin comes from and where it ultimately goes. This task required installing a streamflow-gaging station at the base of the watershed to measure water exiting the basin (streamflow), monitoring 14 ground-water observation wells throughout the watershed to measure changes in ground-water storage, installing 2 recording precipitation gages within the watershed, operating 1 manual precipitation gage for quality assurance/quality control of data from the 2 recording gages, and obtaining the volume of water transferred into or out of the watershed from various water users and suppliers within the watershed. From these data, the amount of evaporation from the watershed could be estimated, as well as the quantity of surface runoff (overland flow), ground-water recharge, and groundwater discharge into the stream (base flow).

A fluvial geomorphic assessment, broadly following the guidelines described in Rosgen (1996), documents the current physical characteristics of the Broad Run stream channel, the current stability of the stream channel, and the vulnerability of the stream channel to future land-use changes within the watershed. As part of this assessment, the entire stream was delineated, or mapped, by use of a stream classification system developed by Rosgen (1996). A stream class is simply a way of categorizing a segment of a stream or reach on the basis of its pattern, profile, and dimension as it would appear when water completely fills the channel; these classifications allow one to make consistent comparisons of one stream to another, identify disturbed reaches of a stream channel, and gain insight as to how a stream channel will evolve. After Broad Run and its tributaries were classified, three reaches along the main channel of Broad Run were identified for a detailed geomorphic analysis; for each reach, the hydraulic geometry of the channel was surveyed, and the materials within the channel (bed material) were measured and evaluated. Factors, such as the bankfull channel dimensions, size of the materials on and under the streambed, water velocity, stream slope, and channel roughness, were recorded and (or) calculated. On the basis of these evaluations, it was determined whether the stream channel was graded and competent (or stable) in its present form and whether the reach was vulnerable to future disturbances upstream within the watershed. From the findings of this assessment, the overall stability and vulnerability of the watershed to future land-use change were described.

A stream-quality assessment was completed to describe the available habitat and quantify the current biologic and chemical characteristics within the stream channel of Broad Run. The stream-quality assessment was done as part of the Chester County Biological Monitoring Network, a long-term chemical and biologic sampling program (Reif, 2002). Three stream reaches-selected to represent conditions in the upper, middle, and lower parts of the watershed-were sampled for benthic macroinvertebrates and water chemistry. Sampling locations were selected on the basis of drainage area, suitable invertebrate sampling substrate, changes in land use, and accessibility. These sites underwent an extensive collection, description, and evaluation of benthic macroinvertebrates, measurement of field-chemical characteristics $(\mathrm{pH}$, dissolved oxygen, specific conductance, and temperature), and detailed water-quality analyses (chemical analyses for nutrients, ions, and (at the most downstream site) metals). All three sites received a habitat evaluation based on the U.S. Environmental Protection Agency (USEPA) Rapid Bioassessment Protocols (Barbour and others, 1999). These protocols describe habitat available to aquatic life in a comprehensive and consistent manner so that broad comparisons can be made among all stream reaches and so that available habitat can be described in terms of its effectiveness in promoting a diverse and healthy aquatic ecosystem. Data from this stream-quality assessment can be used by environmental managers as a comparative tool to ensure water quality and available instream habitat and to promote a healthy and diverse assemblage of aquatic life within Broad Run.

\section{Environmental Hydrologic Setting}

The Broad Run watershed drains $7.08 \mathrm{mi}^{2}$ to the West Branch Brandywine Creek. The entire watershed is within the Piedmont Upland Section of the Piedmont Physiographic Province, which is described by Sevon (2000) as consisting mainly of broad, rounded to flat-topped hills and shallow valleys developed on schist, gneiss, and quartzite with some saprolite (weathered and decomposed rocks). The local relief of the Piedmont Upland Section is low to moderate, with altitudes ranging from about 100 to 1,220 ft; however, within the Broad Run watershed, altitudes range from approximately $200 \mathrm{ft}$ near the mouth of Broad Run to approximately $600 \mathrm{ft}$ in the headwaters

\footnotetext{
${ }^{1}$ Terms defined in the Glossary are in bold type where first used.
} 


\section{Environmental Setting, Water Budget, and Stream Assessment for the Broad Run Watershed, Chester County, Pa.}

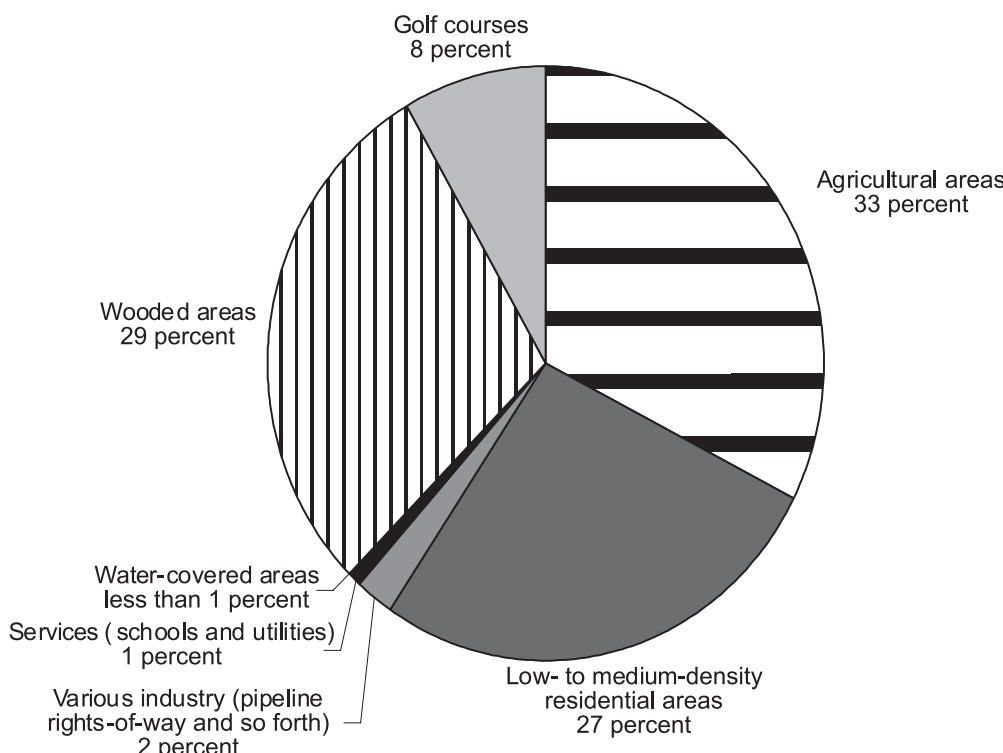

Figure 2. Land-use percentages within the Broad Run watershed, Chester County, southeastern Pennsylvania (U.S. Geological Survey, 1996). of the basin. The rocks in this section of the watershed are intensely folded and faulted, and the resulting drainage pattern is primarily dendritic (similar to the branch structure on a tree).

Land use and (or) land cover within the Broad Run watershed is about evenly distributed among agriculture, woodland, and low-to medium-density residential land (fig. 2). Since the mid-1900s, 8 percent, or $0.58 \mathrm{mi}^{2}$, of the watershed formerly listed as predominantly agricultural was developed into the current Tattersall Golf Club (Stacy Wallace, Tattersall Golf Club, oral commun., 2004). The small percentage of land within the watershed not categorized above (approximately 4 percent) is covered by water (such as streams and ponds), used by municipal services (such as schools), and (or) used as rights-of-way for sewer lines, water lines, or other utilities, as shown in figure 2 (U.S. Geological Survey, 1996).

\section{Geology}

The rocks underlying Chester County are divided into three main terranes (or areas with the same type of rocks); these are the Mesozoic Terrane in the northern part of the county, the Lancaster Terrane in the center of the county, and the Brandywine Terrane in the southern part of the county (Sloto, 1994). The Broad Run watershed lies within the Brandywine Terrane.

Within the boundaries of the Broad Run watershed, the Brandywine Terrane is further divided into two structural groups, made up of metamorphic rocks from different geologic periods. The younger of the two groups is known as the Glenarm supergroup and makes up the steep hills and valleys in the upper part of the watershed; the rocks within this group date from the middle Ordovician to the late Precambrian geologic periods from about 450 to 540 million years ago. The older, underlying, group is known as the West Chester Massif and makes up some of the southeastern part of the watershed; the rocks within this group date from the Precambrian geologic period more than about 540 million years ago.

These two structural groups can be further divided into smaller geologic formations, which are generally more relevant to this study than the larger terranes and groups. Extent of and differences between geologic formations are commonly subject to interpretation; for this report, the formations within the Broad Run watershed (fig. 3 and table 1) will be described as in Sloto (1994). On top of these geologic formations and within the stream valleys of the Broad Run watershed is alluvium-loose sands, gravels, and soils that fill valleys as adjacent hillsides are eroded over time. The alluvium within the Broad Run watershed was deposited largely during the Quaternary geologic period (within the last 1.8 million years) and is, thus, known as Quaternary Alluvium; however, the erosion and deposition process continues today.

Various geologic formations are at the surface in multiple places within the watershed (fig. 3); for example, the Wissahickon Schist Formation crops out in two distinct bands that apparently are not connected within the watershed. Such multiple occurrences are mainly the result of folding and faulting of rocks that have lifted older, deeper formations in relation to the younger formations above. This type of structural deformation can greatly alter the surface and subsurface geologic and geomorphic properties within a watershed and can, thus, greatly affect the flow paths of surface water and (or) ground water. For example, a tributary to Broad Run flows down a valley created by the large fault that bisects the watershed (fig. 3).

Formations composing the Glenarm supergroup that can be readily observed as outcrops (areas of exposed rock) within the watershed include the Peters Creek Schist, Wissahickon Schist, Octoraro Phyllite, and Cockeysville Marble. The formations containing phyllite and schist, which underlie the majority of the watershed, are hard and generally consist of many very thin layers (some as thin as a sheet of paper), called laminae. Phyllites and schist generally began as fine muds deposited near 




Figure 3. Geologic formations and selected hydrologic features within the Broad Run watershed, Chester County, southeastern Pennsylvania. 


\section{Environmental Setting, Water Budget, and Stream Assessment for the Broad Run Watershed, Chester County, Pa.}

Table 1. Detailed descriptions of the geologic formations within the Broad Run watershed, Chester County, southeastern Pennsylvania.

\begin{tabular}{|c|c|c|}
\hline Formation & Age & Description \\
\hline Quaternary Alluvium & Quaternary & $\begin{array}{l}\text { Quaternary alluvium is present as fine- to medium-grained unconsolidated material in } \\
\text { and along stream valleys as stream-bottom and flood-plain deposits. The alluvium } \\
\text { consists mostly of silt, sand, and gravels mixed with locally derived cobbles (Sloto, } \\
\text { 1994). }\end{array}$ \\
\hline Peters Creek Schist & $\begin{array}{l}\text { Middle Ordovician } \\
\quad \text { (Berg and others, 1983) }\end{array}$ & $\begin{array}{l}\text { The Peters Creek Schist consist of a flyschoid sequence of metagraywacke and pelite } \\
\text { rich in quartz and magnetite (Lyttle and Epstein, 1987). The Peters Creek Schist is } \\
\text { generally a green, fine-grained, finely laminated, mica schist with numerous thin to } \\
\text { thick interbeds of chlorite-bearing granular quartzite. The pelitic part is usually a } \\
\text { quartz-muscovite-chlorite-orthoclase schist (Sloto, 1994). }\end{array}$ \\
\hline Wissahickon Schist & $\begin{array}{l}\text { Upper Cambrian to } \\
\text { Lower Ordovician } \\
\text { (Berg and others, 1983) }\end{array}$ & $\begin{array}{l}\text { The Wissahickon Schist consists of metasediments metamorphosed to amphibolite } \\
\text { grade. It conformably overlies Cockeysville Marble and Setters Quartzite; however, } \\
\text { where they are absent, the Wissahickon is in fault-contact with the underlying } \\
\text { gneiss. The Wissahickon is a light to medium gray, fine- to medium-grained } \\
\text { quartzo-aluminous schist and gneiss. Composition ranges from quartz-orthoclase- } \\
\text { biotite and orthoclase-quartz-muscovite schist to quartz-biotite-plagioclase and } \\
\text { quartz-plagioclase-biotite schistose gneiss. Garnet and (or) sillimanite are locally } \\
\text { abundant. Foliation is generally very well developed (Sloto, 1994). }\end{array}$ \\
\hline Cockeysville Marble & $\begin{array}{l}\text { Middle Cambrian } \\
\quad \text { (Berg and others, 1983) }\end{array}$ & $\begin{array}{l}\text { The Cockeysville Marble is a white, coarse-grained, saccharoidal marble and light } \\
\text { gray, fine-grained, banded marble. The Cockeysville Marble commonly contains } \\
\text { scattered, golden-brown phlogopite flakes (Sloto, 1994). }\end{array}$ \\
\hline Octoraro Phyllite & $\begin{array}{l}\text { Upper Proterozoic to } \\
\text { Middle Cambrian } \\
\text { (Sloto, 1994) }\end{array}$ & $\begin{array}{l}\text { The Octoraro Phyllite is a bluish-gray to greenish-gray, well-foliated, quartz-musco- } \\
\text { vite-chlorite phyllite with lustrous, smooth laminae. It commonly contains quartz } \\
\text { lenses parallel to the laminae around which foliation wraps. Locally, a purplish slate } \\
\text { may be present, and small plagioclase crystals are common in some of the layers } \\
\text { (Sloto, 1994). }\end{array}$ \\
\hline $\begin{array}{l}\text { Felsic Gneiss, Amphibo- } \\
\text { lite Facies }\end{array}$ & $\begin{array}{l}\text { Middle Proterozoic } \\
\text { (Sloto, 1994) }\end{array}$ & $\begin{array}{l}\text { The felsic gneiss, amphibolite facies, of the West Chester Massif is described as a } \\
\text { light- to medium gray, medium-grained, finely to coarsely layered quartz-plagio- } \\
\text { clase-biotite, potassium feldspar-garnet gneiss with, or without, hornblende (Sloto, } \\
\text { 1994). }\end{array}$ \\
\hline
\end{tabular}

the shoreline of an ancient ocean. These muds were slowly buried and compressed by additional layers of sediment over millions of years; the tremendous weight of these additional sediments eventually turned the mud into a sedimentary rock known as shale. As even more heat and pressure were added by later mountain-building forces, the shale was metamorphosed into phyllite; and some phyllite, with even more heat and pressure, was metamorphosed into schist.

The Cockeysville Marble was produced in a similar manner; however, it began as an organic-rich mud in deeper waters farther from shore. This mud was made up mainly of dead microorganisms that settled to the bottom along with the waste products from the organisms living in the waters above; these muds were, consequently, high in calcium from shells and carbon from sea life. These organic-rich muds were slowly buried and compressed over time by additional layers of sediment and, eventually, turned into a sedimentary rock known as limestone. This limestone, along with the other rocks in the region, was further heated and compressed by mountain-building forces and eventually turned into the metamorphic rock marble.

Located largely within the southeastern part of the Broad Run watershed, the West Chester Massif consists of only one massive, or nonlayered, rock type known as a [felsic gneiss].
This gneiss was formed by the metamorphosis of a specific type of intrusive igneous rock, which itself was formed long ago as magma (molten rock that never reached the surface in a liquid state), slowly cooled and crystallized. After the magma formed into solid rock, mountain-building forces heated and compressed the rock so intensely that many of its crystal grains actually were flattened and aligned in distinct bands before the rock cooled and hardened again. Even though gneiss is very hard and looks similar to granite, the banded pattern generally makes gneiss distinct. The "felsic" part of "felsic gneiss" simply means that this particular gneiss is composed mainly of the mineral feldspar.

\section{Hydrogeology}

The Peters Creek Schist, Wissahickon Schist, Octoraro Phyllite, and felsic gneiss, as discussed previously, underlie most of the Broad Run watershed. Ground-water flow paths within metamorphic rocks usually take the shortest route available; water flows from hilltops directly to stream valleys, generally following the local topography. Ground water in metamorphic rocks usually is unconfined, and the water table is generally a subdued replica of the land surface (Sloto, 1994). 
Precipitation falling on the metamorphic rocks within the Broad Run watershed will, generally, move as surface runoff and ground water directly downhill toward the nearest stream, unless diverted by pumping wells, lost to evapotranspiration, or taken into storage, and will generally flow out of the basin where Broad Run joins the West Branch Brandywine Creek.

The Cockeysville Marble underlies only a small part of the Broad Run watershed. Carbonate rocks can be dissolved by carbonic acid, which is a common constituent in rainwater; carbonic acid is formed naturally as carbon dioxide in the air combines with rainwater as it falls to earth. As this acidic water slowly dissolves the marble, cavities may develop along fractures and (or) near the contact with other geologic formations; these cavities may, consequently, transmit large amounts of water underground. Local climate and the geochemical composition of the carbonate rocks (which controls how quickly they dissolve) generally determine the manner in which a carbonate stream responds to runoff. Ground-water flow paths within these carbonate geologic settings seldom mimic local topography, and ground water commonly does not flow directly downhill because it moves through solution cavities that are more often controlled by geochemistry and geologic structure than by topography (Schreffler, 1998).

Hydrologic effects due to the properties of the Cockeysville Marble were observed over a short reach of an unnamed tributary to Broad Run. During field visits, this tributary was observed to go dry as it flowed across an area underlain by Cockeysville Marble and reappear from a spring farther downstream (fig. 3). Such loss and (or) gain of streamflow is common as streams flow into carbonate regions, pass into various solution cavities below ground, and emerge from springs farther downstream (generally at geologic contacts with more resistant formations). Also of note is that, based on these field observations, solution cavities may have formed within this particular outcrop of Cockeysville Marble, making future sinkholes in the outcrop area a possibility. Although no sinkholes were observed within the Broad Run watershed, sinkholes have formed within the Cockeysville Marble in nearby West Marlborough and London Grove Townships in Chester County (Kochanov, 2004).

\section{Soils}

Soils within the Broad Run watershed belong to the following groups, or series, of soils: Chester, Chewacla, Glenelg, Glenville, Manor, udorthents (disturbed soils) and urban lands, Wehadkee, and Worsham. These series include many smaller subseries or "phases" of soils that, although similar in overall characteristics, may differ slightly in the lesser characteristics of slope, weathering, and (or) particle size. Although descriptions of soil phases commonly are used for specific purposes, such as engineering and (or) woodland management, the larger, series classification is suitable for the descriptive purpose of this report. Descriptions of soils series are from the 1959 Soil
Survey of Chester and Delaware Counties, Pennsylvania (U.S. Department of Agriculture, 1963) unless noted otherwise.

\section{Chester Series}

The Chester series constitutes less than 1 percent of the soil within the Broad Run watershed (fig. 4) (U.S. Department of Agriculture, 1994). This series is made up of deep, welldrained, productive soils with moderate to moderately rapid permeability and a moderate to moderately high available moisture capacity. The surface layer of these soils is dark brown, and the subsoil is strong brown to yellowish red and friable.

Within the Broad Run watershed, Chester soils are underlain mainly by schist and gneiss, but in other places they can be underlain by other igneous rocks. The Chester soils developed from schist generally become more micaceous (contain more mica) with depth. Soil slopes are commonly from 3 to 10 percent but can range from 0 to 65 percent (U.S. Department of Agriculture, 2004). Depth to bedrock typically ranges from 6 to $10 \mathrm{ft}$ (U.S. Department of Agriculture, 2004). Chester soils are found near soils of the Glenelg, Manor, Glenville, and Worsham series, and all formed on similar parent materials.

Chester soils are generally slightly acid to medium acid. Crops generally respond well if lime and fertilizer are added; therefore, this soil is commonly farmed. Principal crops grown on Chester soils are corn, soybeans, small grains, and (or) hay. This soil is also used for pasture (U.S. Department of Agriculture, 2004). Native vegetation on Chester soils generally consists of hardwoods including white oak, red oak, black oak, hickory, tuliptree, wild cherry, walnut, ash, and maple.

\section{Chewacla Series}

The Chewacla series constitutes about 2 percent of the soil within the Broad Run watershed (fig. 4) (U.S. Department of Agriculture, 1994). This series is made up of deep, moderately well drained soils with moderate permeability and moderate available moisture capacity. The surface layer of these soils is dark brown, and the subsoil is an often mottled yellowish brown or dark brown. Chewacla soils are generally free of large stones. Soil slopes range from 0 to 2 percent, and depth to bedrock is typically greater than $6 \mathrm{ft}$ (U.S. Department of Agriculture, 2004).

Chewacla soils are derived from alluvial sediments washed from soils developed on upland regions and are found near Wehadkee soils. The parent soils of the Chewacla series were initially derived from the weathering of gneiss and schist within the Broad Run watershed. Because of this origin, stratification of the sandy and silty materials occurs in some places, mostly along small streams that are subject to overflow.

Chewacla soils generally are acidic and have a good supply of plant nutrients. Restricted drainage and the hazard of flooding, however, limit the growth of some crops. Much of the area underlain by this soil is, therefore, used for pasture. Native 


\section{Environmental Setting, Water Budget, and Stream Assessment for the Broad Run Watershed, Chester County, Pa.}

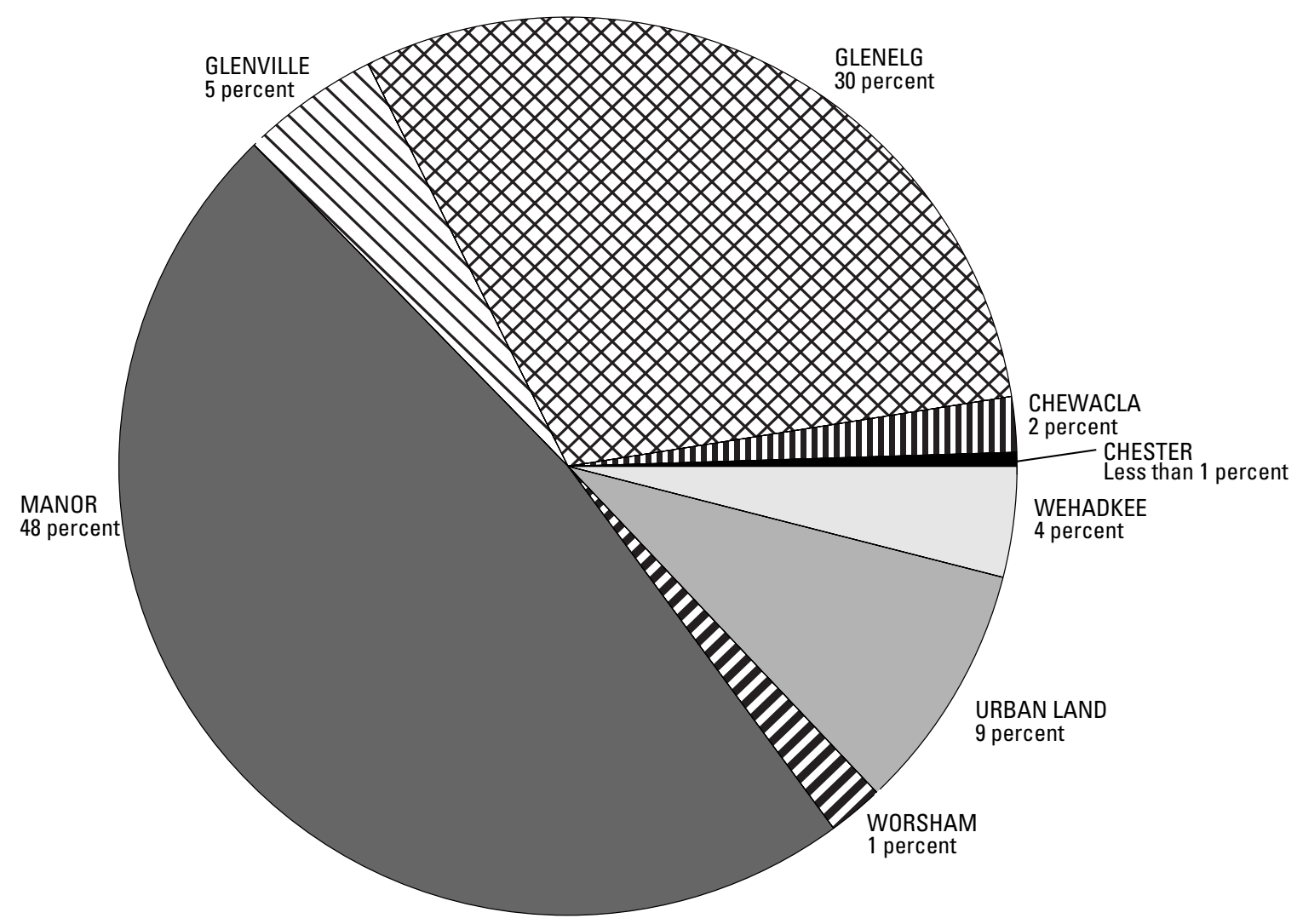

Figure 4. Soil-series percentages within the Broad Run watershed, Chester County, southeastern Pennsylvania (U.S. Department of Agriculture, 1994).

vegetation on Chewacla soil includes, but is not limited to, white oak, red oak, hickory, tuliptree, walnut, and ash.

\section{Glenelg Series}

The Glenelg series constitutes about 30 percent of the soil within the Broad Run watershed (fig. 4) (U.S. Department of Agriculture, 1994). The series is made up of moderately deep, well-drained silt loams on upland areas with moderate permeability and moderate available moisture capacity. The surface layer is generally a dark brown, and the subsoil is generally dark to strong brown with slightly more clay than the upper layer. Beneath the subsoil is commonly a strong-brown or reddishbrown loam that can contain many fragments of mica.

Within the Broad Run watershed, Glenelg soils are underlain mainly by mica schist (U.S. Department of Agriculture, 2004) but are also underlain by gneiss in places. Soil slopes range from 0 to 55 percent, and depth to bedrock is typically from 6 to $10 \mathrm{ft}$ but can be more (U.S. Department of Agriculture, 2004). Glenelg soils are generally found near soils of the Chester, Manor, Glenville, and Worsham series, and all are formed on similar parent materials.
Glenelg soils are generally acidic; therefore, crops do not respond well unless lime is added. Glenelg soils are generally fertile with the addition of lime and well suited to a variety of crops including tree fruits (orchards), row crops, and pasture. Native vegetation on Glenelg soils includes, but is not limited to, white oak, red oak, black oak, hickory, tuliptree, white pine, scotch pine and norway spruce.

\section{Glenville Series}

The Glenville series constitutes about 5 percent of the soil within the Broad Run watershed (fig. 4) (U.S. Department of Agriculture, 1994). The series is made up of deep, moderately well drained soils on low-lying upland areas and around the heads of streams. Glenville soils exhibit moderately slow permeability and moderately high available moisture capacity. The surface layer is generally very dark brown or dark grayish brown, and the subsoil is generally a mottled yellowish brown or strong brown.

Glenville soils are underlain mainly by schist and gneiss within the Broad Run watershed. Soil slopes range from 0 to 15 percent, and depth to bedrock is typically more than $5 \mathrm{ft}$ (U.S. Department of Agriculture, 2004). Glenville soils are gen- 
erally found near soils of the Chester, Glenelg, Manor, and Worsham series.

Glenville soils are generally acidic to very strongly acidic; therefore, crops do not respond well unless lime is added. With the addition of lime, Glenville soils are moderately to highly fertile but retain moisture for fairly long periods; therefore, deep-rooted plants that do not tolerate wetness may not do well on these soils. Native vegetation on Glenville soils includes, but is not limited to, red oak, hickory, elm, ash, walnut, and tuliptree.

\section{Manor Series}

The Manor series constitutes about 48 percent of the soil within the Broad Run watershed (fig. 4) (U.S. Department of Agriculture, 1994). The series is generally made up of deep, well-drained soils on upland areas. Manor soils exhibit moderate to moderately rapid permeability (U.S. Department of Agriculture, 2004) and a generally moderate to low available moisture capacity. The surface layer is generally dark brown, and the subsoil is generally a yellowish red or yellowish brown with large amounts of mica. In many places, this soil may have a slippery, or greasy, feel because of the abundance of mica.

Manor soils are underlain mainly by micaceous schist (U.S. Department of Agriculture, 2004); however, these soils have also been found over gneiss (U.S. Department of Agriculture, 1963). Soil slopes can range from 0 to 65 percent, and depth to bedrock can typically equal or exceed approximately 6 to $10 \mathrm{ft}$ (U.S. Department of Agriculture, 2004). Manor soils are generally found near soils of the Chester, Glenelg, Glenville, and Worsham series.

Manor soils are generally acidic. On lesser slopes, row crops and pasture can often be productive if lime and fertilizer are added; however, on steeper hillsides, Manor soils are generally poorly suited for cultivation. Native vegetation on lesser slopes includes, but is not limited to, red oak, black oak, hickory, beech, and tuliptree. Native vegetation on steeper slopes includes, but is not limited to, the above-mentioned vegetation plus Virginia pine, jack pine, white pine, and pitch pine.

\section{Udorthents and Urban Land}

Udorthents and urban lands are often referred to as "made land" in soils descriptions. These soils are generally the result of other soils being destroyed, covered by other materials, or generally disturbed by urban or industrial development. Because of the great variability introduced by creation of these soils, no general characteristics, such as permeability, can be assigned to the series. Within the Broad Run watershed, udorthents and urban land constitute approximately 10 percent of all soils (fig. 4) (U.S. Department of Agriculture, 1994).

\section{Wehadkee Series}

The Wehadkee series constitutes about 4 percent of the soil within the Broad Run watershed. (fig. 4) (U.S. Department of Agriculture, 1994). The series is generally made up of deep, poorly drained soils on flood plains. Within the Broad Run watershed, Wehadkee soils are moderately permeable and have a high water table through most of the year. The surface layer is dark grayish brown, and the subsoil is yellowish brown. In most places, stratified sand and silt occur in these soils.

Within the watershed, Wehadkee soils are generally formed by alluvium washed by streams from upland soils underlain by schist and gneiss. These soils form in valley bottoms and, subsequently, have generally flat slopes; soil depths are typically about $4 \mathrm{ft}$. Within the watershed, Wehadkee soils are generally found near soils of the Chewacla series.

Wehadkee soils are generally acidic within the watershed. Frequent flooding and a high water table restrict root growth and limit commercial crops. Native vegetation includes, but is not limited to, red maple, alder, ash, elm, and sycamore with lesser amounts of white and red oak.

\section{Worsham Series}

The Worsham series constitutes about 1 percent of the soil within the Broad Run watershed (fig. 4) (U.S. Department of Agriculture, 1994). The series is generally made up of deep, moderately well drained soils on upland areas. These soils are found mainly in marshy areas fed by springs at the heads of streams, along small streams, in slight depressions, and the base of slopes; as a result, these soils are often saturated, poorly aerated, and slowly permeable. The surface layer is dark grayish brown or black, and the subsoil is yellowish brown.

Worsham soils are underlain mainly by weathered schist and gneiss within the Broad Run watershed, but these soils can form on other rock types. Soil slopes are generally slight, ranging from 0 to 3 percent. Depth to bedrock varies but typically exceeds $5 \mathrm{ft}$. Worsham soils are typically found near soils of the Chester, Glenelg, and Glenville series.

Because of frequent saturation, Worsham soils are not easily penetrated by roots, thereby limiting commercial crops other than pasture. Worsham soils are strongly acidic and are low in plant nutrients. Native vegetation includes, but is not limited to, red maple and elm with lesser amounts of ash, white oak, black oak, and beech. 


\section{Methods}

Methods used for this study to estimate an annual water budget, assess fluvial geomorphology, and assess stream quality within the Broad Run watershed are described below. All methods are quality assured by standard practices and (or) USGS protocol to ensure consistent, accurate, and reproducible results.

\section{Water Budget}

The basic expression of the annual water budget for the Broad Run watershed is

$$
P=S F+\Delta G W+E T
$$

where $P$ is precipitation, $S F$ is streamflow, $\Delta G W$ is change in ground-water storage, and ET is evapotranspiration loss.

All terms in the water-budget equation are determined from direct measurement except for evapotranspiration (ET) for which the equation is solved. Locations of all precipitation gages, ground-water observation wells, and streamflow-gaging station are shown in figure 5. Water-budget computations are based on hydrologic conditions from April 1, 2003, to March 31, 2004.

Precipitation in the Broad Run watershed was measured at two recording precipitation gages, one near the streamflowgaging station (R1) and a second one at a higher elevation, near Tattersall Golf Club on the watershed divide (R2) (fig. 5). Precipitation amounts may vary throughout a watershed (even in a relatively small basin such as Broad Run); therefore, data from the two recording precipitation gages were averaged to determine a mean precipitation over the entire watershed.

Streamflow draining from the Broad Run watershed was directly measured at USGS streamflow-gaging station 01480638, Broad Run at Northbrook, established near the mouth of Broad Run (figs. 5 and 6). Drainage area above this station is $6.39 \mathrm{mi}^{2}$ of the total $7.08 \mathrm{mi}^{2}$ within the watershed. Runoff from the remaining $0.69 \mathrm{mi}^{2}$ of the watershed was accounted for by increasing measured streamflow by 10 percent.

Streamflow in this water budget was separated into baseflow and direct-runoff components by use of a hydrograph-separation technique known as the local-minimum method of the HYSEP computer program (Sloto and Crouse, 1996). This method uses a hydrograph of mean daily streamflows and determines minimum mean daily values of streamflow on that hydrograph within a given sliding interval. By connecting these local-minimum values into a separate base-flow hydrograph, the amount of streamflow resulting from direct runoff and base flow can be estimated.

Water-level data from 14 observation wells within or directly adjacent to the Broad Run watershed, and within a variety of topographic and geologic settings, were collected monthly to identify usable observation wells and eliminate from consideration observation wells that had water levels subject to pronounced effects from nearby pumping (comprehensive tables are presented in appendix 3). Small effects from nearby pumping were acceptable provided the affected data did not coincide with the beginning or end of the annual water budget, because only the change between the first and last water-level measurements was used to determine the annual change in ground-water storage. On the basis of these criteria, six wells (CH-1158, CH-5071, CH-6666, CH-6667, CH-6668, CH-6672) were selected for use in computation of the annual water budget for the watershed.

Given that aquifer systems within metamorphic rocks are generally controlled by secondary porosity (fractures within the rocks) and not primary porosity (water moving through the rocks themselves), data from the above mentioned six observation wells were averaged to best determine the general character of water-level change within the watershed. In aquifer systems controlled by secondary porosity, large differences in absolute water levels and (or) response to nearby pumping stresses are common in relatively close wells if the fractures intersected by those wells are not the same.

The average of the observed annual changes in water levels within these six wells was multiplied by 0.08 , the specific yield of the zone of water-level fluctuation (McGreevy and Sloto, 1980). Specific yield is the ratio of the volume of water a rock will yield if allowed to drain, by gravity only, to the volume of the rock; for example, if the water level drops $1 \mathrm{ft}$ in a well within the Broad Run watershed, this drop equates to approximately $0.08 \mathrm{ft}$ of actual water because the space taken up by the rocks from which the water drains must be accounted for. By multiplying the observed annual change in water level by specific yield, the change in water level within the observation wells can be directly related to the amount of water entering or leaving ground-water storage.

\section{Fluvial Geomorphology}

Assessment of fluvial geomorphology (including geomorphic stream classifications subsequently used for this study) is highly dependent on the correct identification of the bankfull channel (Rosgen, 1996). Small increases in streamflow occur very often in response to runoff but do not have the capacity to shape the stream channel (because of insufficient energy to erode and transport sediment); large floods can drastically alter the stream channel but do not occur very frequently. Consequently, a stream channel is formed primarily by streamflows at or near bankfull discharge, which are relatively frequent and have sufficient power to move much of the material within the stream channel. Bankfull discharge is often related to the 1- to 2-year flood-recurrence interval, or that flood with a probability of occurring every 1 to 2 years on average. Identifying the bankfull channel can be difficult because indicators marking the elevations and boundaries of the bankfull channel can be hard to find and measure in the field. Terraces (remnants of past stream-channel flood plains), scour lines, depositional features 




Base from USGS Digital Orthophoto Quardrangle Coatesville, 1999 and Unionville, 1999

EXPLANATION

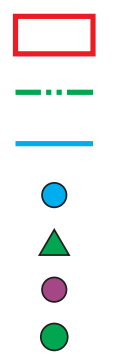

BROAD RUN WATERSHED

TOWNSHIP BOUNDARY

BROAD RUN AND TRIBUTARIES

RECORDING PRECIPITATION GAGE (R2)

$\triangle$ STREAMFLOW AND RECORDING PRECIPITATION GAGE (R1)

- GROUND-WATER OBSERVATION WELL AND MANUAL PRECIPITATION GAGE

GROUND-WATER OBSERVATION WELL

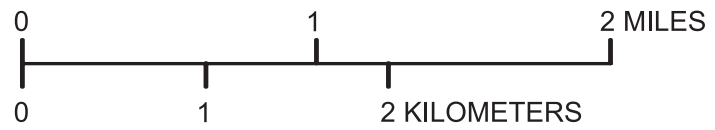

Figure 5. Locations of ground-water observation wells, recording precipitation gages, and streamflow-gaging station within the Broad Run watershed, Chester County, southeastern Pennsylvania. 


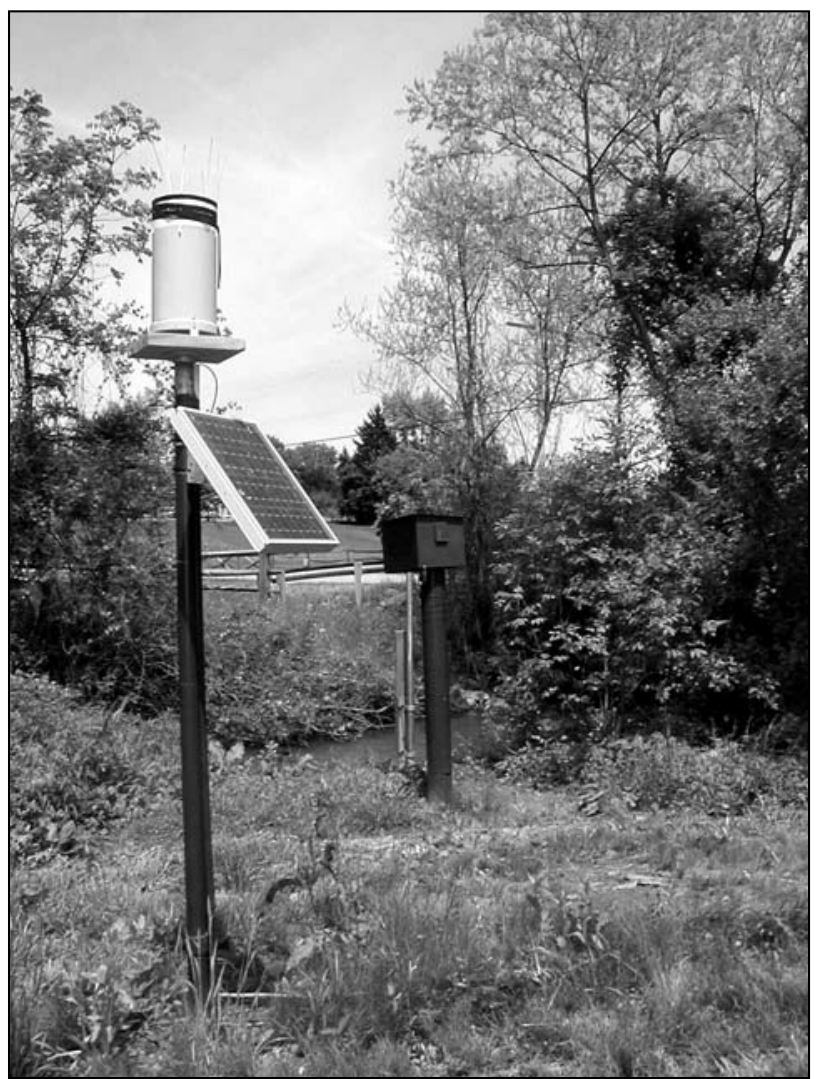

Figure 6. View of U.S. Geological Survey streamflow-gaging station 01480638 showing recording precipitation gage with solar panel, gage shelter, and crest-stage gage, Chester County, southeastern Pennsylvania (Photograph courtesy of Craig Thomas, Chester County Water Resources Authority, 2003).

left by past floods, and (or) heavy vegetation commonly hamper interpretation of which indicator is the result of the recent bankfull discharge and which is the result of large floods in the past.

In order to increase the reliability of the field interpretation of bankfull indicators, regional hydraulic geometry curves developed for the Piedmont Physiographic Province in Pennsylvania and Maryland (Cinotto, 2003) were used. Regional hydraulic geometry curves relate the bankfull-channel area, width, and mean depth, as well as bankfull discharge, to drainage areas of streams with similar runoff characteristics. To determine the correct bankfull-channel feature, bankfull area, width, and mean depth are measured directly from surveyed cross sections and compared to regional-curve data for validation. Prior to use of regional hydraulic geometry curves, bankfull discharge must be measured directly from manual streamflow measurements or calculated from survey data by means of the following equation:

$$
Q=V A \text {, }
$$

where

$Q$ is bankfull discharge, in cubic feet per second;

$V$ is bankfull velocity, in feet per second;

and

$A$ is bankfull area, in square feet.

Velocity in the above equation is calculated by means of the Manning equation, given as

$$
V=\left(1.49 R^{2 / 3} S^{1 / 2}\right) / n,
$$

where

$V$ is bankfull velocity, in feet per second;

$R$ is bankfull hydraulic radius, in feet;

$S$ is bankfull slope, in feet per foot;

and

$n$ is Manning's roughness coefficient.

Manning's roughness coefficient $(n)$ may be estimated by graphical means as described in Rosgen (1998) or by visual means as described in Barnes (1967).

After correctly identifying the bankfull channel for a given stream reach and the corresponding discharge, the first phase of the fluvial-geomorphic assessment, the geomorphic stream classification, was begun. The classification system used for this phase of the study was a simplified version of the system developed by Rosgen (1996), which broadly categorizes the character of a stream reach on the basis of its morphology (or form). A simplified classification system worked for this study because most stream reaches within the Broad Run watershed were observed directly by USGS personnel on the ground; this direct observation allowed for quick selection of stream class based on entrenchment ratio, bankfull width to depth ratio, and slope and eliminated the need to assess stream sinuosity, as is often required when direct observation is impossible or impractical.

The first step in the geomorphic stream classification was to estimate the predominant entrenchment ratio along a given reach of stream. The entrenchment ratio is the width that the stream would reach if it were at a flood stage equal to twice the maximum depth of the bankfull channel divided by the width at the top of the bankfull channel. The second step was to estimate the predominant bankfull width to depth ratio of the same reach of stream. The bankfull width to depth ratio is the maximum width at the top of the bankfull channel divided by the mean depth of the bankfull channel. The third step was to estimate the predominant slope of the bankfull channel along the reach of stream; for this broad classification of stream class, coarse slope estimates were assigned categorically. These parameters were then entered into table 2 (modified from Rosgen, 1996, fig. 5-3) to determine the stream classification for the reach. These data, for all stream reaches within the Broad Run watershed, were then compiled and are described in detail below. Areas dominated by features, such as lakes, ponds, or wetlands, were not classified by this method. The boundaries between stream reaches of various stream classes were plotted at the approxi- 
Table 2. Geomorphic data categories used in delineation of stream classes within the Broad Run watershed, Chester County, southeastern Pennsylvania.

[ft/ft, feet per foot, <, less than; >, greater than; classifications modified from Rosgen, 1996]

\begin{tabular}{|c|c|c|c|c|c|c|}
\hline Stream classification & $\mathrm{A}$ & $\mathrm{G}$ & $\mathrm{F}$ & B & $\mathrm{E}$ & $\mathrm{C}$ \\
\hline $\begin{array}{l}\text { Width/Depth ratio } \\
(+ \text { or }-2.0)\end{array}$ & $<12$ & $<12$ & $>12$ & $>12$ & $<12$ & $>12$ \\
\hline
\end{tabular}

mate location where the stream types were observed to change on maps, on aerial photographs, and (or) in field observations; these boundaries are generally not hard-line boundaries but rather areas where morphology of the stream channel changes gradually.

The second phase of the fluvial geomorphic assessment, which generally was based on the level II and level III assessment methods developed by Rosgen (1996, 1998, 2002), involved much more intensive and descriptive study of selected reaches throughout the watershed. This intensive study was required to estimate the current stability of the stream channel and the vulnerability of the stream channel to future land-use or hydrologic changes within the watershed. For this second phase, three stream reaches were selected at approximately the top, middle, and bottom of the main channel of Broad Run. At each reach, three detailed surveys were done: a longitudinal profile (side view of the stream channel) and two cross-section surveys (perpendicular "slices" through riffles in the stream channel) (fig. 7). Rebar was driven below grade at the ends of each cross section, and a global positioning system (GPS) was used to mark the endpoints of all surveys so that future recovery

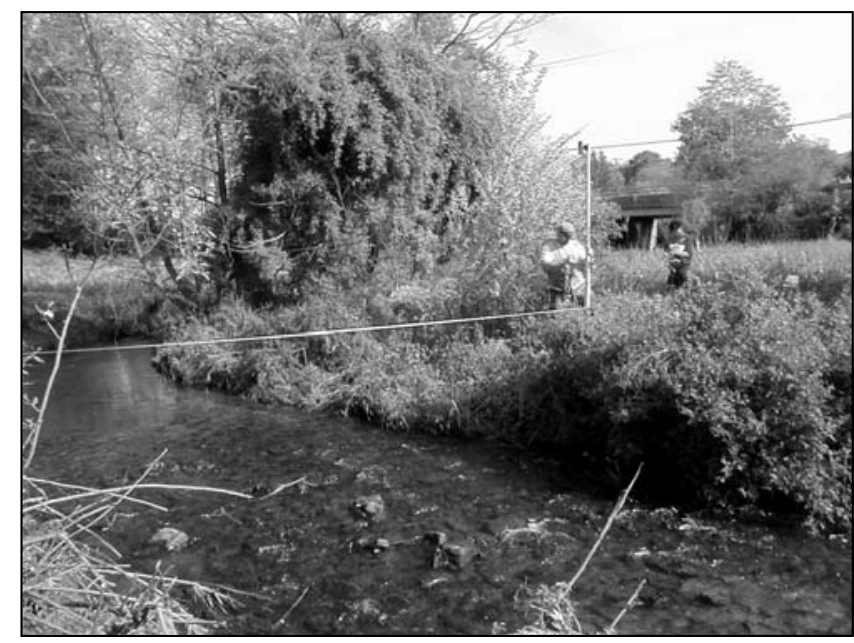

Figure 7. U.S. Geological Survey personnel surveying cross section on Broad Run, Chester County, southeastern Pennsylvania (Photograph courtesy of Craig Thomas, Chester County Water Resources Authority, 2003). and study would be possible (fig. 8). At each cross section, a pebble count, adopted from Wolman (1954), was done to determine the particle-size distribution of the streambed materials (fig. 9). One core sample also was collected at each cross section by excavating materials within a plastic cylinder that had been pressed into the sediment (fig. 10); these sediments were later sieved in the laboratory. Data from these core samples were used to determine the particle-size distribution of materials that were potentially mobile (entrained) during stream-channel formation. Core samples were collected from the downstream third of a point bar at an approximate elevation equal to half the distance between the deepest part of the bankfull channel and the top of the bankfull channel. These core samples were collected on the nearest point bar to the riffle wherein the cross-section survey was completed. If no depositional feature, such as a point bar, was present, core samples were collected from the streambed within the same riffle wherein the crosssection survey was completed. Digital photographs also were taken at each geomorphic study site to document current site conditions, and ancillary data, such as the valley type (Rosgen, 1996), were noted.

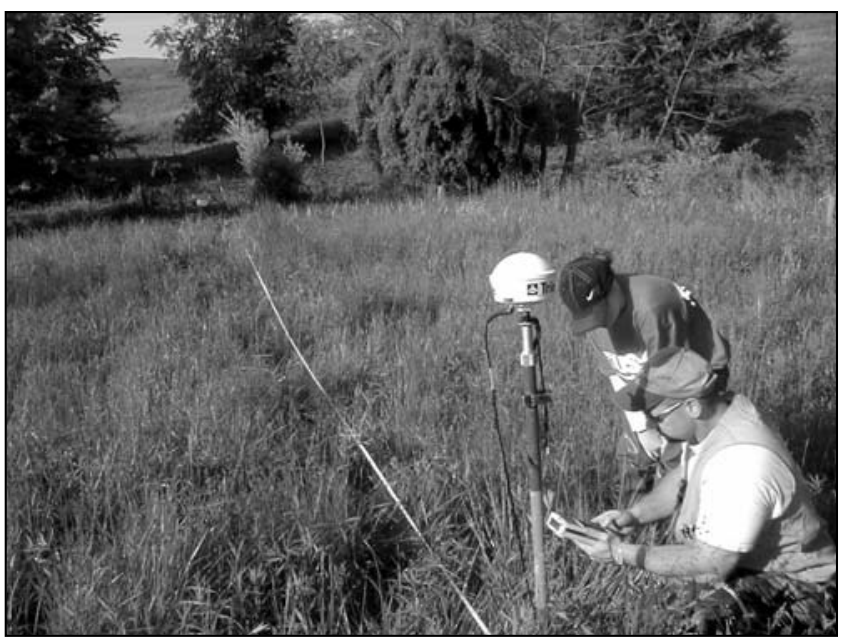

Figure 8. U.S. Geological Survey personnel collecting global positioning system data on Broad Run, Chester County, southeastern Pennsylvania (Photograph courtesy of Craig Thomas, Chester County Water Resources Authority, 2003). 




Figure 9. U.S. Geological Survey technician making a pebble count, Chester County, southeastern Pennsylvania. (Photograph by P.J. Cinotto, U.S. Geological Survey).

Subsequent data analysis for intensive, geomorphic study reaches generally was divided into five steps, as described in Rosgen (2002): basic data processing and tabulation, calculation of critical dimensionless shear stress, calculation of mean depth required for entrainment of the largest particle in the core sample, calculation of the bankfull slope required for entrainment of the largest particle in the core sample, and sediment transport validation, a step that determines the largest particle that could be moved under bankfull flow given the tractive

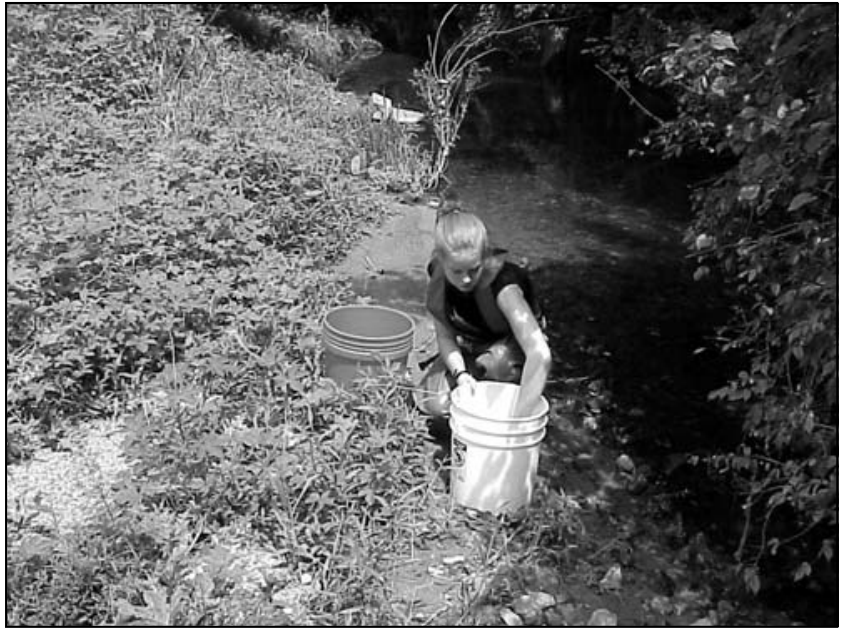

Figure 10. U.S. Geological Survey technician collecting core sample, Chester County, southeastern Pennsylvania. (Photograph by P.J. Cinotto, U.S. Geological Survey).

force or shear stress. Basic data processing and tabulation involves the reduction of field data into detailed descriptive data (as per Rosgen level II assessment criteria; Rosgen, 1998) and quantitative variables for subsequent use in calculations that determine the stability of the stream channel (as per Rosgen level III assessment criteria; Rosgen, 2002). Descriptions of data used for geomorphic analysis are presented in table 3, and descriptions of the data required for subsequent stability calculations are presented in table 4 .

Table 3. Data required for fluvial geomorphic analysis of intensive study sites, Broad Run, Chester County, southeastern Pennsylvania, 2003.

\begin{tabular}{|c|c|}
\hline Data type ${ }^{1}$ & Description of data ${ }^{1}$ \\
\hline Bankfull width & Width of the stream channel, at bankfull stage elevation, in a riffle section (feet). \\
\hline Bankfull mean depth & $\begin{array}{l}\text { Mean depth of the stream-channel cross section, at bankfull stage elevation, in a riffle section } \\
\text { (feet). }\end{array}$ \\
\hline Bankfull cross-sectional area & $\begin{array}{l}\text { Area of the stream-channel cross section, at bankfull stage elevation, in a riffle section (square } \\
\text { feet). }\end{array}$ \\
\hline Bankfull maximum depth & Maximum depth of the bankfull channel cross section in a riffle section (feet). \\
\hline Channel materials: $D_{50}$ and $D_{84}$ & $\begin{array}{l}\text { The particle size (D) greater than } 50 \text { or } 84 \text { percent, respectively, of all particles sampled from } \\
\text { the streambed (millimeters). }\end{array}$ \\
\hline Core samples: $D_{50} \wedge$ and $D i$ & $\begin{array}{l}\text { The } D_{50} \wedge \text { particle size is greater than } 50 \text { percent of all particles within the core sample; the } D i \\
\text { particle size is the largest particle in the core sample (millimeters). }\end{array}$ \\
\hline Bankfull water-surface slope & $\begin{array}{l}\text { The water-surface slope representing the gradient at bankfull stage through the respective cross } \\
\text { section (feet/foot). }\end{array}$ \\
\hline Stream reach sinuosity & The ratio of stream length divided by the valley length. \\
\hline Stream class & $\begin{array}{l}\text { The descriptive categorization of the bankfull stream channel by the pattern, profile, and dimen- } \\
\text { sion of that channel as per Rosgen (1996). }\end{array}$ \\
\hline Valley type & The descriptive categorization of stream valley as per Rosgen (1996). \\
\hline
\end{tabular}

\footnotetext{
${ }^{1}$ Modified from Rosgen, 1998
} 
Table 4. Required data for use in fluvial geomorphic stability calculations at intensive study sites, Broad Run, Chester County, southeastern Pennsylvania, 2003.

[mm, millimeter; ft/ft, feet per foot, ft, feet]

\begin{tabular}{cl}
\hline $\begin{array}{c}\text { Para- } \\
\text { meter }\end{array}$ & \multicolumn{1}{c}{ Description of parameter } \\
\hline$D_{50}$ & $\begin{array}{c}\text { Particle diameter greater than } 50 \text { percent of all } \\
\text { particles on the streambed within the riffle } \\
(\mathrm{mm}) .\end{array}$ \\
& $\begin{array}{c}\text { Particle diameter greater than } 50 \text { percent of all } \\
\text { particles within the core sample }(\mathrm{mm}) .\end{array}$ \\
$D_{50} \wedge$ & Largest particle in core sample $(\mathrm{mm})$. \\
$D^{\prime}$ & Existing bankfull slope at cross section $(\mathrm{ft} / \mathrm{ft})$. \\
$\mathrm{d}$ & Existing mean bankfull depth at cross section $(\mathrm{ft})$. \\
$\mathrm{R}$ & Hydraulic radius (ft)
\end{tabular}

Dimensionless critical shear stress is calculated by use of one of three equations, depending on specific site conditions, or parameters (table 5). Dimensionless critical shear stress values are needed for determining the tractive forces required within the stream channel to initiate particle movement and, consequently, alter the stream-channel morphology.

Calculation of mean depth required for entrainment of the largest particle in the core sample determines the depth at which the armoring layer of the streambed, within a specific cross section, will potentially be transported. This calculation is based on the dimensionless critical shear stress calculation and follows an equation given by Rosgen (2002):

$$
\mathrm{d}_{\mathrm{r}}=\tau_{\mathrm{ci}}^{*} \gamma_{\mathrm{s}} D i / S
$$

where

$\mathrm{d}_{\mathrm{r}}$ is mean depth required to initiate movement of $\mathrm{Di}$, in feet;

$\tau^{*}{ }_{\mathrm{ci}}$ is dimensionless critical shear stress;

$\gamma_{\mathrm{s}}$ is submerged specific weight of sediment;

$D i$ is largest particle in core sample, in feet; and

$S$ is present bankfull slope, in feet per foot.

Calculation of the slope required for the entrainment of the largest particle in the core sample determines the slope at which the armoring layer of the streambed, within a specific cross section, will potentially be transported. This calculation also is based on the dimensionless critical shear stress calculation and follows an equation given by Rosgen (2002):

$$
S_{r}=\tau^{*}{ }_{c i} \gamma_{s} \mathrm{Di} / d,
$$

where

$S_{r}$ is slope required to initiate movement of $D i$, in feet per foot;

and

$d$ is present bankfull mean depth, in feet.

Table 5. Parameters and associated equations for the determination of dimensionless critical shear stress, Broad Run, Chester County, southeastern Pennsylvania, 2003.

$\left[\tau_{\mathrm{ci}}^{*}\right.$, dimensionless critical shear stress; $D_{50}$, particle size greater than 50 percent of all particles in streambed sample (in millimeters); $D_{50} \wedge$, particle size greater than 50 percent of all particles in core sample (in millimeters); $D i$, largest particle in core sample (in millimeters)]

\begin{tabular}{lll}
\hline \multicolumn{3}{c}{ Selection of dimensionless critical shear stress equation } \\
\hline \multicolumn{1}{c}{ Parameter } & \multicolumn{1}{c}{ Equation } & Reference \\
\hline$D_{50} / D_{50} \wedge=3$ to 7 & $\tau^{*}{ }_{\mathrm{ci}}=0.0834\left(\mathrm{D}_{50} / \mathrm{D}_{50} \wedge\right)^{-0.872}$ & Rosgen, 2002 \\
$\mathrm{Di} / \mathrm{D}_{50}=1.3$ to ${ }^{1} 3$ & $\tau^{*}{ }_{\mathrm{ci}}=0.0384\left(\mathrm{Di} / \mathrm{D}_{50} \wedge\right)^{-0.887}$ & Rosgen, 2002 \\
If none of the above are met & $\tau^{*}{ }_{\mathrm{ci}}=0.0834\left(\mathrm{Di} / \mathrm{D}_{50}\right)^{-0.872}$ & Andrews, 1984 \\
\hline
\end{tabular}

\footnotetext{
${ }^{1}$ This parameter was originally presented in Rosgen (2002) with two significant figures (1.3 to 3.0); however, the significance of upper range of this parameter was reduced to one for this study on the basis of site observations.
} 


\section{Environmental Setting, Water Budget, and Stream Assessment for the Broad Run Watershed, Chester County, Pa.}

Sediment transport validation determines the particle size that may potentially be moved on the basis of the calculated shear stress within the cross section, and it relates that particle size to the required mean depth and required slope calculations above. For example, if the above equations indicate that more depth and slope are needed to initiate movement of the largest particle in the respective core sample, the sediment transport validation should yield a moveable particle size smaller than that largest particle. This validation process begins with calculation of shear stress within the cross section based on the following equation:

$$
\tau_{\mathrm{o}}=\gamma R S
$$

where

$\tau_{\mathrm{o}}$ is shear stress, or unit tractive force, within the cross section, in pounds per square foot;

$\gamma$ is unit weight of water $\left(62.4 \mathrm{lb} / \mathrm{ft}^{3}\right)$;

$R$ is hydraulic radius at the cross section, in feet; and

$S$ is present bankfull slope, in feet per foot.

From the above calculation of shear stress within the cross section, the following equation (from the equation originally developed by Shields (1936)) is used to estimate a representative particle that may be moved under the given tractive force or shear stress within the respective cross section (note that $\tau$ approximates $\tau_{\mathrm{o}}$ ):

$$
D_{s}=\tau / \theta_{\mathrm{c}} \gamma / s,
$$

where

$D_{s}$ is representative movable particle size, in feet;

$\tau$ is critical shear stress, or unit tractive force, within the cross section, in pounds per square foot;

$\theta_{\mathrm{c}}$ is Shields parameter;

$\gamma$ is unit weight of water $\left(62.4 \mathrm{lb} / \mathrm{ft}^{3}\right)$; and

$\gamma_{s}$ is submerged specific weight of sediment (for quartzose sediment $=1.65$ ) .

The Shields equation is dependent on a constant that is selected to represent the relative condition of the streambed; this constant, known as the Shields parameter, is, in effect, a version of the above dimensionless critical shear stress that has been adjusted to match data from laboratory and (or) field data. Gordon and others (1992) define the Shields parameter with respect to various stream conditions listed in table 6; however, other research has suggested subtle variations to these ranges. The bed materials of Broad Run generally were described as loosely packed gravels throughout the stream's length; consequently, a range of Shields parameters ( 0.015 to 0.035$)$ was selected to bracket a representative range of particles that may be potentially moved under the given tractive force or shear stress within each respective cross section during bankfull flow.
Table 6. Shields parameter classifications used for fluvial geomorphic assessment of Broad Run, Chester County, southeastern Pennsylvania,

2003.

$\left[\theta_{\mathrm{c}}\right.$, Shields parameter; from Gordon and others, 1992; >, greater than]

Suggested values for the Shields parameter, for mixed bed sediments

\begin{tabular}{lc}
\hline \multicolumn{1}{c}{ Condition of streambed } & $\theta_{\mathrm{c}}$ \\
\hline $\begin{array}{l}\text { Loosely packed: "quicksands" and gravels with } \\
\text { large, water-filled voids. }\end{array}$ & 0.01 to 0.035 \\
$\begin{array}{l}\text { Normal: uniform materials of a "settled" bed } \\
\text { with fairly random grain arrangements. }\end{array}$ & 0.035 to 0.065 \\
$\begin{array}{l}\text { Closely packed: smaller materials fill the voids } \\
\text { between larger particles. }\end{array}$ & 0.065 to 0.10 \\
\begin{tabular}{l} 
Highly imbricated. \\
\hline
\end{tabular} & $>0.10$ \\
\hline
\end{tabular}

\section{Stream-Quality Assessment}

Three stream reaches representing the upper, middle, and lower parts of the watershed were sampled between 1999 and 2002 for benthic macroinvertebrates and water chemistry. These sites underwent an extensive collection, description, and evaluation of benthic macroinvertebrates, on-site measurement of chemical and physical characteristics ( $\mathrm{pH}$, dissolved oxygen, specific conductance, and temperature), and detailed waterquality analyses (chemical analyses for nutrients, ions, and metals at the most downstream site). All three sites received an evaluation of habitat based on the U.S. Environmental Protection Agency (USEPA) Rapid Bioassessment Protocols (Barbour and others, 1999). These sites were part of a long-term biologic monitoring project that collected annual benthicmacroinvertebrate and water-chemistry data throughout Chester County, Pennsylvania (Reif, 2002).

Dissolved oxygen, $\mathrm{pH}$, water temperature, specific conductance, alkalinity, and streamflow were measured at the same time and location as the biologic samples were collected. Water-quality measurements were made at various locations along a cross section to determine the mixing conditions at each sampling location (fig. 11).

Samples for chemical analysis were collected at each sampling location by use of techniques described by Wilde and others (1999). Because the samples were collected at base flow and all of the streams sampling locations were shallow and well mixed, a non-isokinetic (variable flow) sample was collected from a single point near the center of flow. Chemical samples were analyzed at the USGS National Water-Quality Laboratory in Arvada, Colo., for nutrients, major ions, and selected metals according to methods in Fishman and Friedman (1989) and Wershaw and others (1987).

The habitat-quality assessment was done at each site at the time of biologic sampling and during the summer. Measurements such as stream width and depth, available substrate, embeddedness, sediment deposition, and bank stability were 


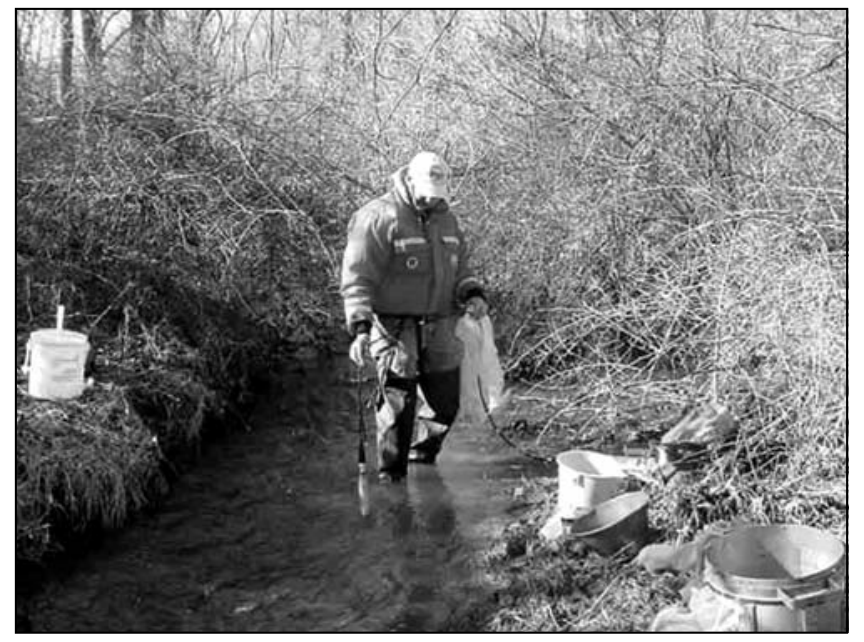

Figure 11. U.S. Geological Survey biologist measuring water chemistry of Broad Run, Chester County, southeastern Pennsylvania. (Photograph by P.J. Cinotto, U.S. Geological Survey).

made from various cross sections in a 300-ft reach that included the biologic sampling area (riffle). All evaluations were done at base flow.

Biologic samples consisted of benthic macroinvertebrates collected from within a riffle (fig. 12). Samples were collected from areas of various velocities by use of a Hess sampler with a mesh size of $500 \mu \mathrm{m}$. The Hess sampler is a metal cylinder with a net attached to capture dislodged organisms (Merritt and Cummins, 1996). The metal cylinder is approximately $0.5 \mathrm{~m}$ in diameter and samples an area of $0.8 \mathrm{~m}^{2}$. All collections were made in triplicate for a total area of $2.4 \mathrm{~m}^{2}$. The samples were composited into a container and preserved in 95 percent ethanol. The entire sample was sieved through a 500- $\mu \mathrm{m}$ sieve prior to sorting to remove large debris and other waste materials. Benthic macroinvertebrates were identified to the lowest practical taxonomic level (usually genus).

Benthic-macroinvertebrate data were summarized by means of two biologic metrics: Ephemeroptera, Plecoptera, and Trichoptera (EPT) taxa richness and the Hilsenhoff Biotic Index (HBI) (Hilsenhoff, 1982). EPT taxa richness is the total number of taxa within the orders Ephemeroptera (mayflies), Plecoptera (stoneflies), and Trichoptera (caddisflies). These three orders of insects generally are considered pollution sensitive, and their presence is associated with good stream quality (Klemm and others,1990). EPT taxa richness generally increases with improving stream quality. HBI is based on the sensitivity of organisms to organic pollution, water quality, and habitat conditions. The HBI assigns tolerance values that range from 0 (least tolerant) to 10 (most tolerant) with respect to organic pollution, water quality, and habitat conditions. Organisms intermediate in their tolerance are assigned intermediate values (Hilsenhoff, 1982). The HBI is determined by multiplying the number of individuals of each taxon by its assigned tolerance value, summing these products, and dividing by the total number of individuals. Tolerance values are from the genus and



Figure 12. U.S. Geological Survey biologist collecting benthicmacroinvertebrate sample from Broad Run, Chester County, southeastern Pennsylvania. (Photograph by P.J. Cinotto, U.S. Geological Survey).

species-level biotic index developed by the State of New York (Bode, 1991).

\section{Quality Assurance / Quality Control}

Quality-assurance and quality-control procedures adhered to published guidelines, as referenced below, and (or) were designed to ensure the accuracy and precision of all data with respect to the required analysis and (or) interpretation. Data falling outside set quality-assurance and quality-control bounds are not used and (or) are used with explanation of the limitations of those data. Quality-assurance and quality-control procedures are described below in detail.

\section{Water Budget}

Precipitation data were quality controlled by comparison of data between multiple gages. Precipitation data from two recording precipitation gages within the watershed were averaged for the year and compared to data from a nearby National Oceanic and Atmospheric Association (NOAA) weather station in Coatesville, $\mathrm{Pa}$. These data were within 5 percent for the yearly total precipitation and indicate that all precipitation gages were functioning properly. Precipitation data from individual storms were compared between both recording precipitation gages and a manual precipitation gage randomly throughout the year. These comparisons were qualitative, and values appearing reasonably close were considered a sufficient check of recording precipitation-gage operation. Data from the manual precipitation gage are not presented in this report.

Data collected from streamflow-gaging station 01480638 (Broad Run at Northbrook, Pa.) were computed, checked, and reviewed by USGS personnel and adhered to quality-assurance/ 


\section{Environmental Setting, Water Budget, and Stream Assessment for the Broad Run Watershed, Chester County, Pa.}

quality-control standards as applicable for all USGS streamflow-gaging stations (Rantz and others, 1982).

Ground-water levels were measured monthly in 14 observation wells to identify periods when a specific well may have been subject to pumping stress. Effects of pumping stress were detected by comparing trends in water levels among observation wells that previously exhibited similar responses to climatic change. Intermittent departures from these trends were determined to have been caused by a cone of depression developing around a nearby actively pumping well or wells. If identified pumping stress interfered with the critical beginning or ending of the annual water-budget period, the well was omitted from analysis.

\section{Fluvial Geomorphology}

Field determination of bankfull indicators was confirmed by use of regional hydraulic geometry curves. Various independent observations were made of the bankfull-channel indicators in the field by other USGS personnel to verify interpretations and minimize inconsistencies. Variables such as velocity of streamflow and (or) the associated Manning's $n$ variable were measured directly and (or) back-calculated from actual discharge measurements to check graphic and (or) computed values within the same or similar geomorphic study reaches. All fluvial-geomorphic procedures followed those described in Cinotto (2003) and Rosgen (1996, 1998, 2002).

\section{Stream-Quality Assessment}

Water-quality-control samples were collected as part of the Chester County Biological Monitoring Network and were not collected specifically at the three Broad Run sites (Reif, 2002). Five percent of samples collected were replicates and field blanks. Constituent concentrations in field blanks were less than the minimum reporting levels, and the measured properties and constituents of replicate samples were within 10 percent. The results indicate no systematic bias and good precision in the reported water-quality data. Analytical performance of the laboratory was evaluated by means of quality-control data from the USGS National Water-Quality Laboratory's Standard Reference Water Sample Program.

Although the habitat assessment was qualitative, quality control was addressed by doing multiple assessments at selected sites to check for inconsistencies and bias in the ratings. Benthic-macroinvertebrate sorting efficiency was evaluated by resorting of selected completed samples. Unusual taxa were confirmed by a taxonomist and comparison to a reference collection of identified organisms. 


\section{Water Budget}

A water budget is a basic tool for estimating the amount of water entering and leaving a watershed over a given period as well as interpreting the hydrologic processes acting on water that enters, resides within, and leaves the watershed; these processes are collectively known as the hydrologic cycle. For this study, a 1-year annual water budget was determined for the Broad Run watershed to quantify the components of the hydrologic cycle. Data for this water budget were collected from April 1, 2003, through March 31, 2004, and are representative of the hydrologic conditions during that period only.

Within the Broad Run watershed, ground-water and surface-water divides coincide, meaning no water flows underground beneath the confines of the hills surrounding Broad Run; therefore, water can be said to generally enter the Broad Run watershed as precipitation and leave as streamflow and evapotranspiration.

Water can also be released from and (or) taken up by soil moisture and (or) ground-water storage after entering the watershed. Because this annual water budget began and ended in the spring when the soil is assumed to be saturated, soil-moisture terms cancel out, and the net change in soil moisture for the year is assumed to equal zero. Actual calculation of soil moisture is complex, requires additional instrumentation, and is beyond the scope of this study. Ground-water storage (water added to, or released from, aquifers) is directly measured by means of the observation-well network described earlier.

Ground-water withdrawals within the watershed by means of public-supply wells and (or) irrigation wells also must be considered in any water budget. Several small-volume publicsupply wells are within the Broad Run watershed, as is a golf course that regularly withdraws water for irrigation. Public-supply wells in the Broad Run watershed generally serve areas that use on-lot treatment systems for sewage disposal. The use of on-lot treatment systems allows approximately 90 percent of the water pumped from these wells to return as recharge, with approximately 10 percent lost to consumptive use. Based on available data (Chester County Planning Commission, 1991; Chester County Water Resources Authority and others, 2001), water withdrawals from public-supply wells in the Broad Run watershed ranged from about $90 \mathrm{Mgal}$ in 1991 (0.7 in.) to a conservative $128 \mathrm{Mgal}$ in 2001 (1.0 in.), the latter amount including withdrawals from some wells outside the watershed. Given that approximately 90 percent of this water re-entered the watershed as recharge, the net loss was only 0.07 to $0.10 \mathrm{in}$. of water through consumptive use. These values are negligible for determination of an annual water budget; however, withdrawals from these public-supply wells likely affected the proportions of some water-budget components because water was lost to consumptive use and not to ground-water evapotranspiration or base flow. Future additions of public sewer systems within the Broad Run watershed will likely cause the losses due to consumptive use to increase, thus, heightening the importance of withdrawals from these wells. The Tattersall Golf Club also withdrew $11.5 \mathrm{Mgal}$ (0.1 in.) of ground water for irrigation use during this annual period (Annie Cerminara, International Golf Maintenance, Inc., oral commun., 2004). This water was discharged on fields within the watershed and, consequently, returned to the hydrologic cycle with no net effect on the overall annual water budget. However, these irrigation withdrawals likely affected the proportions of some water-budget components because most of this water was eventually lost to evapotranspiration at land surface and not to ground-water evapotranspiration or base flow. This result is largely due to matching of irrigation rates to the uptake rates of the plants being irrigated-in this case, turf grass.

Imported water can be a component of an annual water budget provided that large quantities are imported, are discharged into the watershed, and affect the natural balance of the hydrologic cycle. Data on quantity of imported water generally are available directly from the local water-supply companies and businesses using the water. Tattersall Golf Club, the only known substantial importer of water into the Broad Run watershed, occasionally imports water from a public water-supply company for irrigation; however, the club did not import any water during the period of data collection, so the importedwater component is, therefore, not applicable for this water budget. All residential areas within the Broad Run watershed served by public water originating outside the watershed also were served by a sanitary-sewer system that transported wastewater out of the watershed (Jack Hines, West Bradford Township, oral commun., 2003); these residential areas, therefore, had no net effect on the annual water budget.

\section{Precipitation}

Total precipitation measured from April 1, 2003, to March 31, 2004, was 67.0 in. at R1 and 68.5 in. at R2, yielding a watershed average of $67.8 \mathrm{in}$. This average compares well with the $65.3 \mathrm{in}$. of precipitation measured at the nearby NOAA weather station at Coatesville, Pa., (approximately $8 \mathrm{mi}$ west of the watershed) during the same period (U.S. Department of Commerce, 2003-04). The precipitation at Coatesville during this period was the largest total precipitation measured during the past 10 years. Precipitation at Coatesville weather station averaged 49.5 in. between 1995 and 2004 (April to March periods); the maximum total was 65.3 in. during 2004, and the minimum was 35.3 in. during 2002. However, a precipitation total for 2003 was not available from this weather station because of missing data during September 2003. These data indicate that the annual water budget completed for the Broad Run watershed for the period of April 2003 to March 2004 is representative of a high-precipitation year and will likely differ from subsequent drier years.

\section{Runoff}

Data from the USGS streamflow-gaging station on Broad Run showed that 38.8 in. of water drained from the watershed 
into the West Branch Brandywine Creek during the study period. Of the 38.8 in. of total streamflow that left the Broad Run watershed, 7.3 in. (approximately 18.7 percent) was from direct runoff and $31.5 \mathrm{in}$. (approximately 81.2 percent) was from base flow. (Direct runoff is the component of streamflow that enters the stream channel promptly after rainfall or snowmelt, primarily as overland flow directly into the stream. Base flow is the component of streamflow that originates as precipitation within the watershed, infiltrates into the ground, and slowly discharges into the stream by such means as springs, seeps, and so forth.) Although not required for presentation of an annual water budget, the monthly values listed in table 7 are converted from cubic feet per second $\left(\mathrm{ft}^{3} / \mathrm{s}\right)$ to inches and totaled to obtain yearly totals and illustrate seasonal differences in streamflow throughout the annual period.

\section{Ground-Water Storage}

The average water-level change in the six observation wells was a 1.78 -ft increase across the basin; the maximum annual change was a $6.75-\mathrm{ft}$ increase at well $\mathrm{CH}-6668$, and the minimum was a $0.48-\mathrm{ft}$ decline at well $\mathrm{CH}-6672$. The average annual water-level change $(1.78 \mathrm{ft})$ was subsequently multiplied by 0.08 , the specific yield of the zone of water-level fluctuation (McGreevy and Sloto, 1980) as described earlier. On the basis of this calculation, $1.71 \mathrm{in}$. of ground water is estimated to have gone into storage (did not discharge into the Broad Run) between April 1, 2003, and March 31, 2004.

\section{Annual Water Budget}

The water-budget equation (eq. 1, p. 10) was used to calculate an annual water budget for the Broad Run watershed for the study period. The average total precipitation within the Broad Run watershed for the April 2003 to March 2004 period was $67.8 \mathrm{in}$., the total streamflow for the $7.08-\mathrm{mi}^{2}$ watershed was 38.8 in., and the change in ground-water storage was estimated to be an increase of 1.71 in. Given these data, the estimated evapotranspiration (ET) for the Broad Run watershed during the study period was $27.3 \mathrm{in}$. This value is comparable to data from Sloto (1990) showing an estimated average ET of 22.90 in. in the nearby Valley Creek watershed of Chester County, Pa., from 1983 to 1987. Sloto's data (1990) included a minimum ET of 18.21 in. in 1987 and a maximum ET of 24.83 in. in 1985.

\section{Ground-Water Recharge}

All ground-water recharge in the Broad Run watershed comes from precipitation. Recharge is affected by many factors including precipitation duration and intensity, antecedent soil moisture, topography, percentage of impervious surface within the watershed, and (or) soil and bedrock characteristics.

Ground-water recharge varies yearly by season and generally

Table 7. Estimated monthly direct-runoff and base-flow components of the total streamflow in the Broad Run watershed, April 2003 to March 2003, Chester County, southeastern Pennsylvania.

[ $\mathrm{ft}^{3} / \mathrm{s}$, cubic feet per second; N/A, not applicable]

\begin{tabular}{cccccccc}
\hline $\begin{array}{c}\text { Month } \\
\text { and year }\end{array}$ & $\begin{array}{c}\text { Mean } \\
\text { stream- } \\
\text { flow } \\
\left(\mathrm{ft}^{3} / \mathrm{s}\right)\end{array}$ & $\begin{array}{c}\text { Mean } \\
\text { base } \\
\text { flow } \\
\left(\mathrm{ft}^{3} / \mathrm{s}\right)\end{array}$ & $\begin{array}{c}\text { Mean } \\
\text { direct } \\
\text { runoff } \\
\left(\mathrm{ft}^{3} / \mathrm{s}\right)\end{array}$ & $\begin{array}{c}\text { Total } \\
\text { stream- } \\
\text { flow } \\
\text { (inches) }\end{array}$ & $\begin{array}{c}\text { Total } \\
\text { base flow } \\
\text { (inches) }\end{array}$ & $\begin{array}{c}\text { Total } \\
\text { direct } \\
\text { runoff } \\
\text { (inches) }\end{array}$ & $\begin{array}{c}\text { Percentage of } \\
\text { streamflow } \\
\text { consisting of } \\
\text { base flow }\end{array}$ \\
\hline $04 / 03$ & 14.4 & 13.3 & 1.2 & 2.3 & 2.1 & 0.2 & 92.2 \\
$05 / 03$ & 10.7 & 9.3 & 1.4 & 1.7 & 1.5 & .2 & 87.6 \\
$06 / 03$ & 30.2 & 22.6 & 7.6 & 4.8 & 3.6 & 1.2 & 74.7 \\
$07 / 03$ & 12.4 & 11.7 & .7 & 2.0 & 1.9 & .1 & 94.4 \\
$08 / 03$ & 10.6 & 7.9 & 2.7 & 1.7 & 1.3 & .4 & 74.6 \\
$09 / 03$ & 33.1 & 19.0 & 14.1 & 5.3 & 3.0 & 2.3 & 57.5 \\
$10 / 03$ & 24.4 & 20.1 & 4.3 & 3.9 & 3.2 & .7 & 82.6 \\
$11 / 03$ & 28.8 & 25.6 & 3.2 & 4.6 & 4.1 & .5 & 88.9 \\
$12 / 03$ & 30.7 & 26.6 & 4.1 & 4.9 & 4.2 & .7 & 86.5 \\
$01 / 04$ & 14.7 & 13.8 & .8 & 2.3 & 2.2 & .1 & 94.4 \\
$02 / 04$ & 19.3 & 14.8 & 4.5 & 3.1 & 2.4 & .7 & 76.9 \\
$03 / 04$ & 13.5 & 12.4 & 1.1 & 2.2 & 2.0 & .2 & 92.1 \\
Total & N/A & N/A & N/A & 38.8 & 31.5 & 7.3 & N/A \\
Average & 20.2 & 16.4 & 3.8 & 3.2 & 2.6 & .6 & 83.5 \\
\hline
\end{tabular}


occurs on hilltops and hillsides (valley bottoms within and near streams are usually areas of discharge). Precipitation that infiltrates the surface replenishes soil moisture first and then can begin to recharge the underlying aquifer.

Ground-water recharge was estimated for the Broad Run watershed using the following equation:

$$
R=B F+\Delta G W+G W E T,
$$

where

$R$ is recharge, in inches;

$B F$ is base flow, in inches;

$\Delta G W$ is change in ground-water storage, in inches; and

GWET is ground-water evapotranspiration, in inches.

As noted above, base flow was determined to be $31.5 \mathrm{in}$. for the 1-year study period, and the increase in ground-water storage was estimated to be $1.71 \mathrm{in}$. for the year. Ground-water evapotranspiration within the region of the Broad Run watershed was estimated to equal approximately $2 \mathrm{in} / \mathrm{yr}$ based on data from Sloto (1994). Given these data, the estimated groundwater recharge for the Broad Run watershed from April 2003 to March 2004 was 35.2 in.

\section{Limitations}

The evapotranspiration (ET) term in this 1-year water budget includes any errors in the measurements of all other waterbudget components, as well as any other water gains or losses in the basin not accounted for in the water-budget equation. This result is a 1-year water budget, and the year studied was characterized by the largest annual precipitation in the past 10 years; changes in future climatic conditions can result in consequent changes to the relative response of individual waterbudget terms.

Short-duration water budgets (such as this annual water budget) generally lack statistical strength for rigorous analysis. Data collected over short time spans-less than approximately 10 years-cannot accurately account for all variability that might be present within a watershed; the most notable of these variations is the difference in weather that may occur from one year to the next.

\section{Summary}

The annual water budget components for the Broad Run watershed are summarized in table 8. Given the proportion of base flow to total streamflow and also considering the total ground-water recharge during this period, the Broad Run watershed can be currently classified as minimally impaired and is generally functioning as expected of a non-urban, mixed-use watershed. Average annual base flow was 31.5 in., approximately 46 percent of the $67.8 \mathrm{in}$. average annual precipitation on the Broad Run watershed and 81 percent of the 38.8 in. total streamflow. This substantial contribution of base flow indicates that ground-water recharge is occurring within the watershed and that the hydrologic function of the Broad Run does not generally appear to be adversely influenced by human activity at present. These data are also consistent with a watershed that has evenly distributed agricultural, wooded, and low- to mediumdensity residential land use and (or) land cover.

The predominance of on-lot sewage-treatment systems within the Broad Run watershed currently allows approximately 90 percent of the water withdrawn from wells in the watershed to recharge the ground-water system. If public sewer systems are installed and wastewater is thereby removed from the watershed, this water must then by accounted for as entirely lost to consumptive use and removed from the water budget. Although treated effluent reduces the potential for the introduction of pathogens into the environment, sufficient increases in consumptive losses may reduce base flow in Broad Run.

The relatively high contribution of base flow to total streamflow within the Broad Run watershed also indicates that base flow is likely a major contributor to the overall biologic diversity and geomorphic stability of Broad Run. Future alterations and (or) development within the watershed that reduce the base-flow component of total streamflow, such as the addition of large impervious areas, will likely adversely affect the overall health of Broad Run. The small relative size of the Broad Run watershed, as compared to other watersheds in the area, also may make this watershed more sensitive to changes in land use than a larger watershed would be; relatively small changes in land use could potentially have large effects on certain components in the annual water budget such as base flow and ground-water recharge.

Table 8. Summary of the annual water budget components determined for the Broad Run watershed, April 2003 to March 2003, Chester County, southeastern Pennsylvania.

[All data are in inches (depth if water were distributed over entire watershed)]

\begin{tabular}{cccccc}
\hline Precipitation & $\begin{array}{c}\text { Total stream- } \\
\text { flow }\end{array}$ & Total base flow & $\begin{array}{c}\text { Total direct } \\
\text { runoff }\end{array}$ & $\begin{array}{c}\text { Change in } \\
\text { ground-water } \\
\text { storage }\end{array}$ & $\begin{array}{c}\text { Ground-water } \\
\text { recharge }\end{array}$ \\
\hline 67.8 & 38.8 & 31.5 & 7.30 & 1.71 & 35.2 \\
\hline
\end{tabular}




\section{Environmental Setting, Water Budget, and Stream Assessment for the Broad Run Watershed, Chester County, Pa.}

\section{Stream Assessment}

A stream assessment of the Broad Run watershed was conducted to assess the physical, biologic, and chemical health of the watershed. Geomorphic parameters, biologic diversity, and chemical properties of the Broad Run were measured and assessed through the course of the study and are described in detail below.

\section{Fluvial Geomorphic Assessment}

The fluvial geomorphic assessment of the Broad Run watershed was done in two parts broadly following the guidelines defined in Rosgen (1996). The basic components of this assessment are divided into two parts on the basis of the level of complexity and scope of work completed.

The first part of the fluvial geomorphic assessment is a delineation of the Broad Run watershed based on the Rosgen geomorphic stream classification (Rosgen, 1996). These geomorphic stream classifications are not used in this report to imply the relative stability or instability of a stream channel (in relation to how sensitive the channel is to future disturbances) but to describe the stream channel based on the relative pattern, profile, and dimension (geomorphic properties). However, because streams do change over time or evolve in relation to the characteristics of the watershed, stream types within a watershed generally can be related to each other by what is termed the "stage of reach evolution" (Simon, 1989). The stage of reach evolution does not imply long-term stability but describes a process that, when used in conjunction with the Rosgen geomorphic stream classification, can be used to identify the previous classification of a stream reach (if it has changed because of disturbance) and the likely future classification as the stream returns to a state of dynamic equilibrium (comes into balance with the water and sediment loads supplied from upstream in the basin).

The second part of the fluvial geomorphic assessment was a detailed analysis of individual stream reaches at key locations within the watershed; in the case of Broad Run, three stream reaches were selected near the approximate top, middle, and bottom of the watershed along the main channel of Broad Run and are described in detail below. These analyses included determination of the entrenchment ratio (Does the stream have an available flood plain?), width to depth ratio (Is the channel narrow and deep or wide and shallow?), channel materials (How big or small is the streambed material?), particle entrainment (How large of a particle can the stream move?), and the slope. On the basis of these measurements and calculations, the force available in the channel to move streambed materials can be estimated, as well as the size and type of the material that is available to be moved. This determination could, therefore, begin to predict how "stable" the stream channel was and how vulnerable the stream channel might be to future changes within the watershed.

\section{Geomorphic Stream Classification of Broad Run Watershed}

The geomorphic stream types within the Broad Run watershed are delineated and presented in figure 13. Based on the total distance of all stream reaches classified within the Broad Run watershed, 61 percent were classified as C-class ${ }^{2}$, 14 percent as E-class, 13 percent as B-class, 5 percent as Fclass, 4 percent as undifferentiated B- and F-class, 2 percent as G-class, and less than 1 percent as A-class.

These fluvial geomorphic stream classes, as noted previously, do not imply stability; however, they are potentially indicative of an evolutionary stage. Simon (1989) and Rosgen (2002), among others, currently have identified at least nine possible scenarios that generally describe common, evolutionary sequences that many natural streams undergo as they progress from an undisturbed state to a disturbed state and back to a new undisturbed state; however, more scenarios will likely be added in the future as they are identified. Of the nine scenarios identified by Simon (1989) and Rosgen (2002), only six currently are applicable to the Broad Run watershed and are presented in figure 14; evolutionary scenarios that involve braided stream channels and (or) other geomorphic conditions that do not currently occur within the Broad Run watershed were omitted. The beginning and end classes of each of the six scenarios presented below generally describe a stream reach that is considered to be in a state of dynamic equilibrium; that is, currently able (under the present hydrologic characteristics of the watershed) to transport the water and sediment supplied from upstream in the watershed without exhibiting signs of rapid erosion or aggradation within the stream channel. Dynamic equilibrium, however, does not imply long-term stability because a seemingly stable stream reach may be at the far ends of an evolutionary scenario and may be on the verge of downcutting or aggrading.

Entrenched stream classes exhibiting little or no available flood plains (G- and F-class streams) are expected by the theory of stream-channel evolution, described above, to be in the center of an evolutionary sequence; these stream reaches likely began as non-entrenched or less-entrenched stream classes (C-, E-, or B-class streams) (fig. 14) and are likely in the process of evolving back into these same classes following an evolutionary sequence described above. This evolutionary process is largely driven because confined streams attempt to erode restrictive banks (those that confine flood waters to a narrow, high-energy channel) and develop a flood plain. The exception, and absent from the evolutionary scenarios (fig. 14), is the Aclass stream channel; one that is generally considered robust

\footnotetext{
${ }^{2}$ Rosgen (1996) refers to classifications as "types." To maintain consistency with other work in Chester County, this report refers to classifications as "classes."
} 


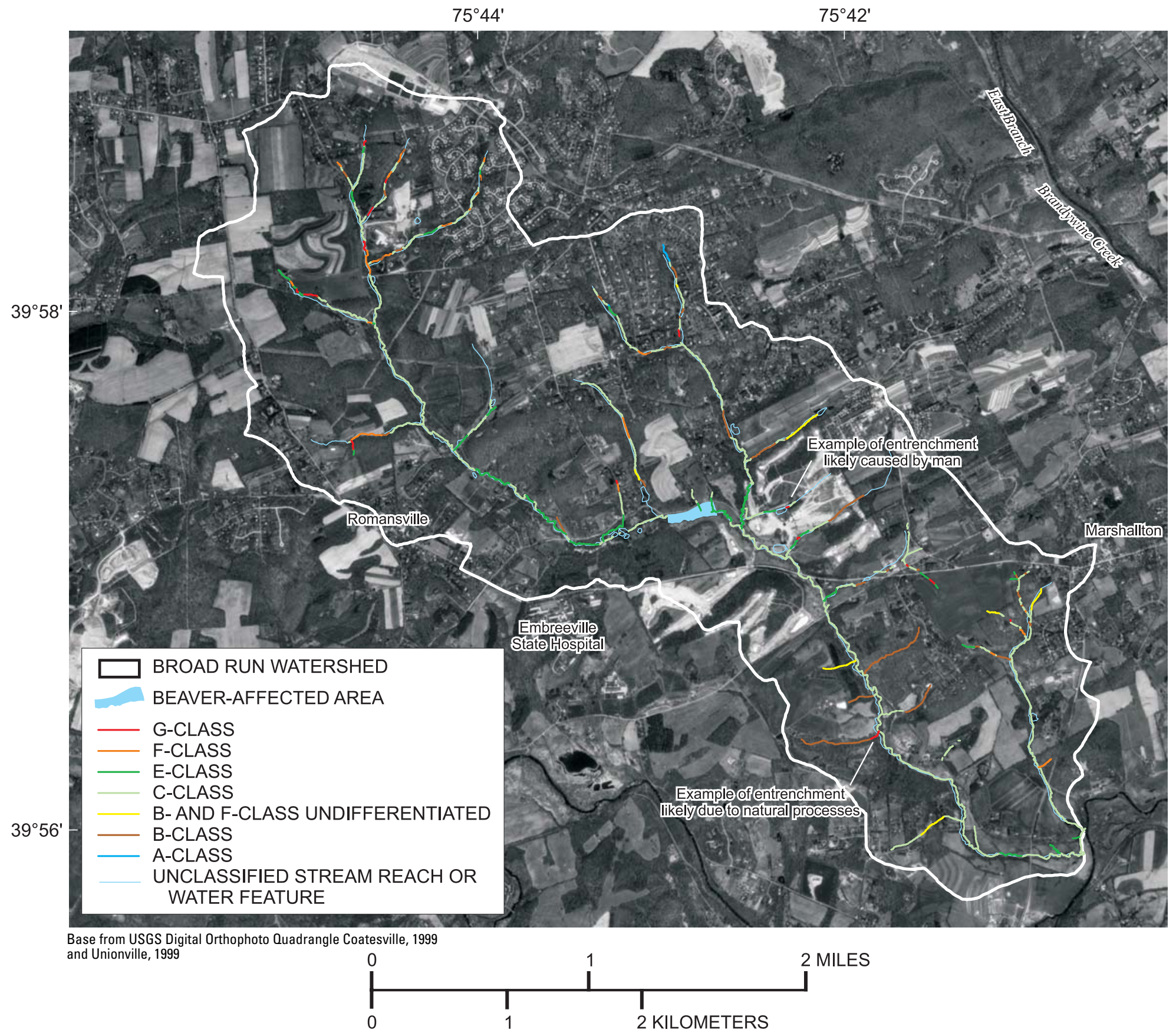

Figure 13. Broad Run and tributaries delineated by stream class (Rosgen, 1996), Chester County, southeastern Pennsylvania. 




Figure 14. Potential stream-channel evolutionary scenarios applicable to Broad Run, Chester County, southeastern Pennsylvania (modified from Rosgen, 2002).

and usually will not evolve into another stream class over a period that is reasonable for description in this context.

To understand this concept of stream-channel evolution, suppose a hypothetical G-class stream type is observed within a stream reach that is predominantly classified as $\mathrm{C}$. This $\mathrm{G}$-class channel is, by definition, entrenched; that is, flood flows are confined in a deep stream channel and cannot easily flow out onto a flood plain. On the basis of the possible evolutionary scenarios in figure 14 (1, 2, and 6), this hypothetical G-class stream reach likely formed by the erosion (downcutting) of a previous C-class stream reach and will likely begin to gradually erode its new streambanks, widening again into a B- or C-class stream reach at a lower elevation. (The ultimate final stream class will depend largely on the slope available and the valley characteristics.) Note that this evolutionary sequence does not quantify the time required for this evolution; only the beginning and end points of the evolution are inferred.

When entrenched stream classes (G- and F-class streams) are interspersed among largely non-entrenched stream reaches (C-, E-, or B-class streams), this entrenchment can often be interpreted stream-channel response to changes in the runoff characteristics of the watershed above; therefore, the presence of G- and F-class streams can often indicate and be used to locate problems with runoff or sediment supplies within the watershed. A clear example of this response to change within the Broad Run watershed is a non-entrenched C-class stream channel (figs. 13 and 15) that has begun to downcut into an entrenched G-class channel (fig. 16). This entrenchment likely occurred in response to increased runoff from the construction of an adjacent housing development (in the background in fig. 16). This G-class channel will likely continue to erode the small waterfall that has formed at its upstream end and move progressively upstream (a process known as head cutting) unless the process is checked by restorative measures and (or) natural factors.

Entrenched stream classes are also often indicative of areas prone to excessive downstream sedimentation that generally results from the entrenchment process. Sediment originat-

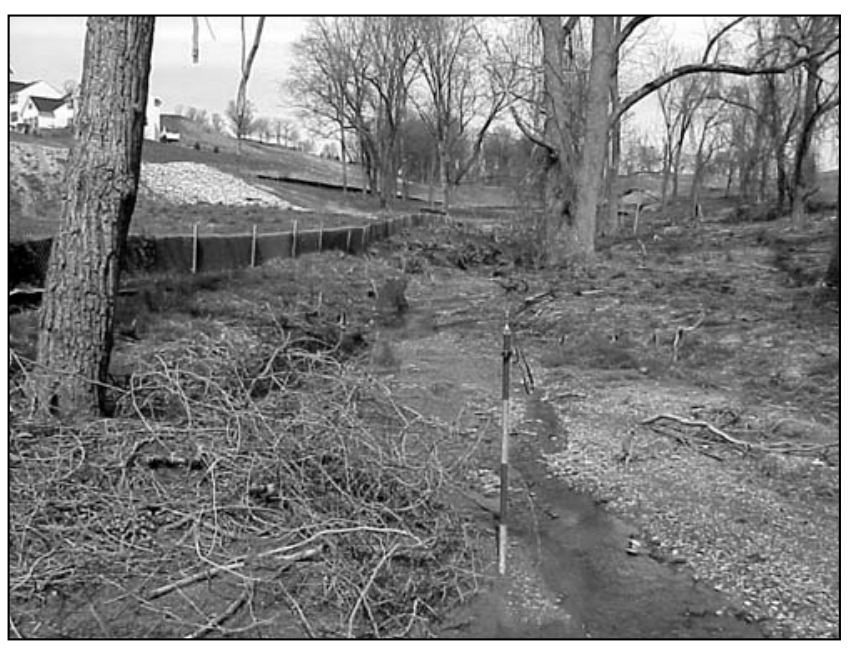

Figure 15. C-class stream channel approximately 100 feet upstream of head cut and resultant G-class stream channel on unnamed tributary to Broad Run, Chester County, southeastern Pennsylvania. (Photograph by P.J. Cinotto, U.S. Geological Survey).

ing from the upstream entrenched stream reach, described above, is contributing to the sediment filling a stormwaterdetention basin directly downstream of the head cut (fig. 17). As this basin fills with sediment, its capacity and its effectiveness to control stormwater runoff are reduced. Excess sediment, if not contained, may also smother fish spawning beds, inundate flood plains, and (or) cause increased flooding within downstream reaches.

G- and F-class stream reaches, which can occur anywhere within a watershed, should not, however, always be interpreted as problematic; because natural processes can also account for entrenched stream classes, each case must be observed and assessed independently. Most notable of these natural processes are the initial formation of stream channels higher up within the headwaters of a stream and (or) the localized entrenchment that may result at the confluence of streams of two unequal sizes 


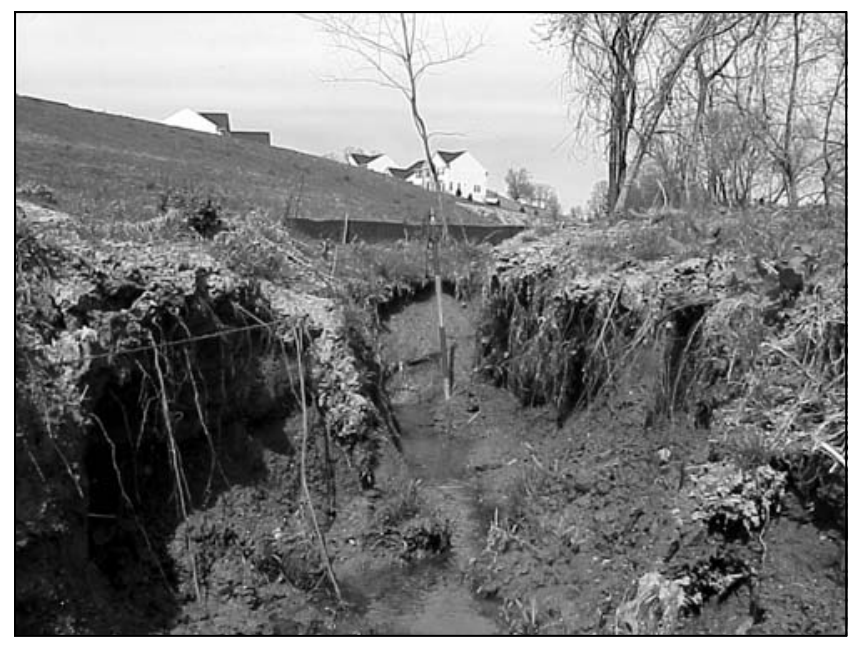

Figure 16. Head cut and resultant $\mathrm{G}$-class stream channel on unnamed tributary to Broad Run, Chester County, southeastern Pennsylvania. (Photograph by P.J. Cinotto, U.S. Geological Survey).

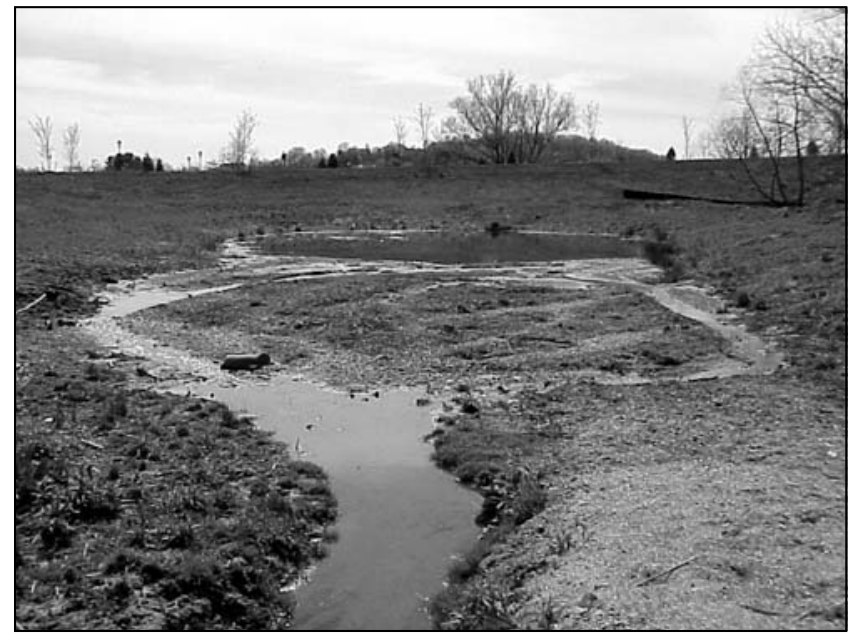

Figure 17. Sediment partially resulting from erosion of unnamed tributary to Broad Run filling stormwater-detention basin, Chester County, southeastern Pennsylvania. (Photograph by P.J. Cinotto, U.S. Geological Survey).

(fig 13). In headwater streams, some erosion can be expected because of natural processes associated with stream-channel evolution. These small streams generally evolve naturally by eroding very small to small, entrenched, rills and gullies that eventually enlarge to form more developed stream channels with associated flood plains (as generally observed on most larger streams within mature valley bottoms). Confluences of smaller tributary channels and larger main-stem streams can also be prone to natural entrenchment and are not always indicative of problems within the watershed. This entrenchment generally results where a relatively small tributary stream flows across flood-plain sediments deposited by a larger stream and cuts a deep channel to reach the lower water-surface elevation of the larger stream. This type of entrenchment is usually local- ized in a short reach along the tributary channel directly adjacent the confluence. In summary, because natural entrenchment can occur within the fluvial environment, identification of a problematic stream reach must be based on direct observation of site conditions adjacent to the entrenched stream reach and consideration of the evolutionary stage of the stream reach as described above.

Other natural factors that affect the morphology and stability of Broad Run are type and concentration of riparian vegetation, natural flooding, and wildlife. For example, beavers have constructed various dams near the approximate center of the watershed (fig. 18), which cause backwater flooding as well as accelerated bank erosion next to the dam. Water flowing over the dam (fig. 18, right side of photo) will eventually erode the bank if the beavers do not continually patch the breach. Bank erosion near a beaver dam (or other obstruction) is the natural result of a stream trying to bypass an obstacle by taking the path of least resistance; the bank material is easier to erode than the obstruction. Another aspect of beaver dams is that they tend to trap sediment behind them. Because the energy of a flowing stream has the capacity to carry a certain amount of sediment, any sediment that settles out behind the dam will be restored downstream by increased erosion. For this reason, waters exiting a dam or any other environment that limits or removes sediment from the stream are termed "sediment starved." In time, because of downstream erosion, the stream class may change accordingly from a non-entrenched class of $\mathrm{C}$ or $\mathrm{E}$ to an entrenched class of $\mathrm{G}$ or $\mathrm{F}$. Removal of woody riparian vegetation by beavers also can make the effected areas susceptible to accelerated bank erosion. Typical beaver-felled trees in a wetland adjacent to Broad Run, newly created by backwater flooding, are shown in figure 19. Even though beavers can seriously affect the stream-channel morphology, they also create a very diverse and important habitat, form wetlands that can filter many pathogens from the water column, and create areas of emergent vegetation.

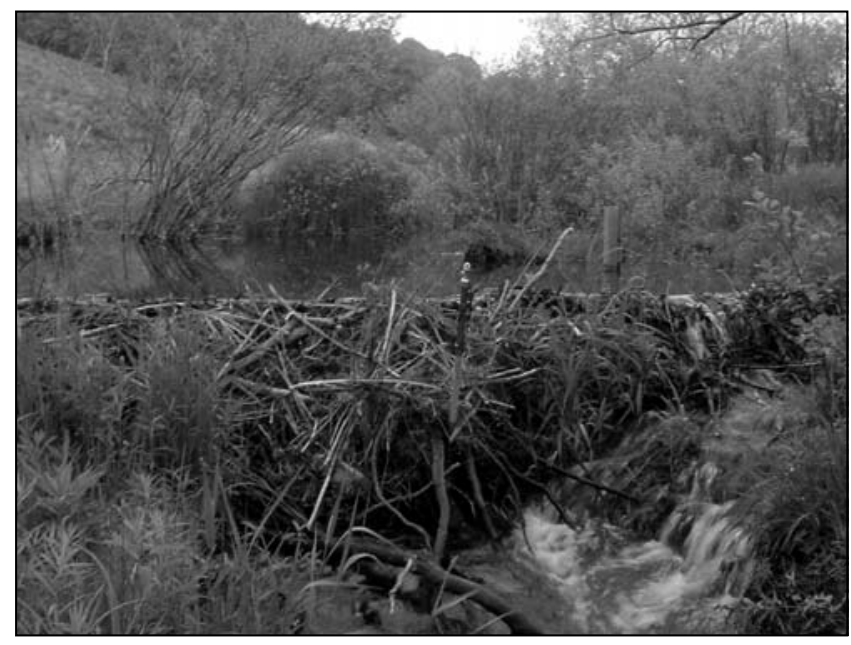

Figure 18. Beaver dam on Broad Run, Chester County, southeastern Pennsylvania. (Photograph by P.J. Cinotto, U.S. Geological Survey). 


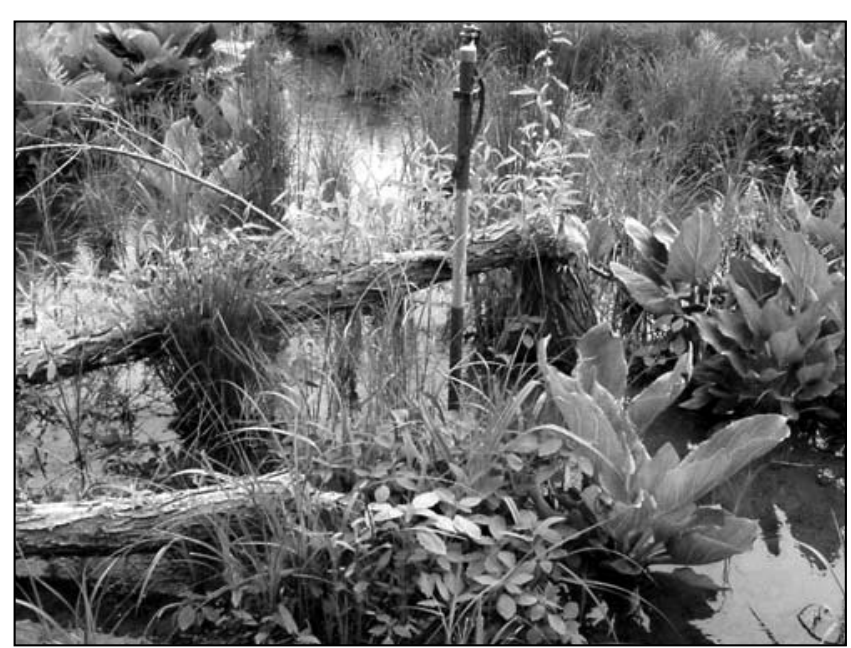

Figure 19. Beaver-felled trees in wetland on Broad Run, Chester County, southeastern Pennsylvania. (Photograph by P.J. Cinotto, U.S. Geological Survey).

\section{Geomorphic Analysis of Broad Run Watershed}

Locations of the three study reaches selected for detailed geomorphic analyses are shown in figure 20, and all data, including the specific location for each survey, are presented in appendix 1 . The three reaches, which were selected to assess fluvial-geomorphic conditions within representative areas of the Broad Run watershed, were the relatively steep and confined headwaters of Broad Run, the relatively wide valley near the center of the watershed, and the bottom of the watershed where Broad Run begins to flow onto the flood plain of the West Branch Brandywine Creek. At each site, the force the stream could exert on the streambed was evaluated against the size of the materials within the stream channel. Imbalances in this relation generally are indicative of either an unstable condition or other factors that may be affecting the hydraulics of the stream reach; for example, excess force could result in increased erosion, whereas too little force could result in aggradation of the stream channel.

\section{Upper Geomorphic Study Reach}

The upper geomorphic study reach is directly adjacent to Broad Run Road (fig. 21); approximately $1.54 \mathrm{mi}^{2}$ of the Broad Run watershed drains to it. This reach lies in a relatively steep and narrow valley dominated by deciduous trees (fig. 22). The bankfull channel was well defined throughout this reach and generally was denoted by an abrupt change in bank angle, changes in riparian vegetation, and depositional features. Broad Run in this area is not entrenched and has an available, functioning flood plain to dissipate the forces associated with natural, intermittent flooding (fig. 22). The channel is also well armored by the outcrops of bedrock.

Geomorphic data collected within this reach indicate that this stream reach currently is stable and in a state of dynamic equilibrium, or in balance with the runoff and sediment load supplied from upstream. Within the most upstream cross section (303 ft downstream from the upstream end of the upper geomorphic study reach), calculations indicate that the stream, at bankfull flow, has the potential to move an estimated 60- to 139-mm particle, whereas the largest particle in a core sample collected from an adjacent point bar $(D i)$ was $144 \mathrm{~mm}$. To move the 144-mm particle, the estimated mean bankfull water depth required would be $0.9 \mathrm{ft}$, and the estimated bankfull water-surface slope required would be $0.009 \mathrm{ft} / \mathrm{ft}$. The measured mean bankfull water depth at cross-section 303 was $1.1 \mathrm{ft}$, and the measured bankfull water-surface slope was $0.011 \mathrm{ft} / \mathrm{ft}$. Within the most downstream cross-section $(691 \mathrm{ft}$ downstream from the upstream end of the upper geomorphic study reach), the stream has the potential to move an estimated 39- to $90-\mathrm{mm}$ particle, whereas the largest particle in a core sample collected from an adjacent point bar $(D i)$ was $170 \mathrm{~mm}$. To move the 170-mm particle, the estimated mean bankfull water depth required would be $1.9 \mathrm{ft}$ and the estimated bankfull water-surface slope required would be $0.011 \mathrm{ft} / \mathrm{ft}$. The measured mean bankfull water depth at cross-section 691 was $1.2 \mathrm{ft}$, and the measured bankfull water-surface slope was $0.006 \mathrm{ft} / \mathrm{ft}$.

Geomorphic data collected within cross-section 303 show similar required and measured values for entrainment of $D i$ under bankfull conditions; this relation indicates that the stream is transporting sediment effectively through this reach and does not currently show tendencies toward aggradation or degradation. The apparent discrepancy in the required and measured values for cross-section 691 is probably due to bedrock outcrops with smooth surfaces that reduce the amount of fine sediment that can accumulate within the reach and also add much larger rocks to the streambed through weathering. If the effects of the bedrock are accounted for, Broad Run currently does not likely have sufficient energy to move the dominant materials on the streambed under bankfull flows and, therefore, erode the streambed. Yet, Broad Run still has adequate energy to transport enough sediment to minimize the potential for aggradation. For example, the $\mathrm{D}_{84}$ (or particle size larger than 84 percent of all particles on the streambed) within cross-section 691 is $58.8 \mathrm{~mm}$, well within the range of the 39 - to $90-\mathrm{mm}$ particle estimated to be mobile under bankfull flows. In summary, the stream channel within the upper geomorphic study reach does not show signs of current or past instability, and it can be considered to be in a state of dynamic equilibrium or balance with the water and sediment being supplied from upstream in the watershed. 




Base from USGS Digital Orthophoto Quardrangle Coatesville, 1999 and Unionville, 1999

\section{EXPLANATION}
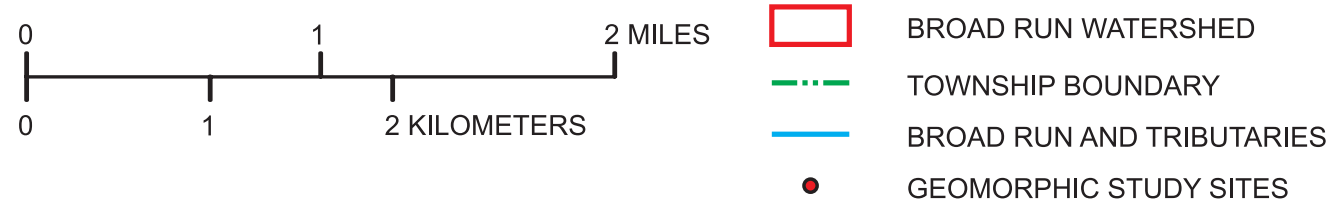

Figure 20. Locations of geomorphic study reaches within the Broad Run watershed, Chester County, southeastern Pennsylvania. 


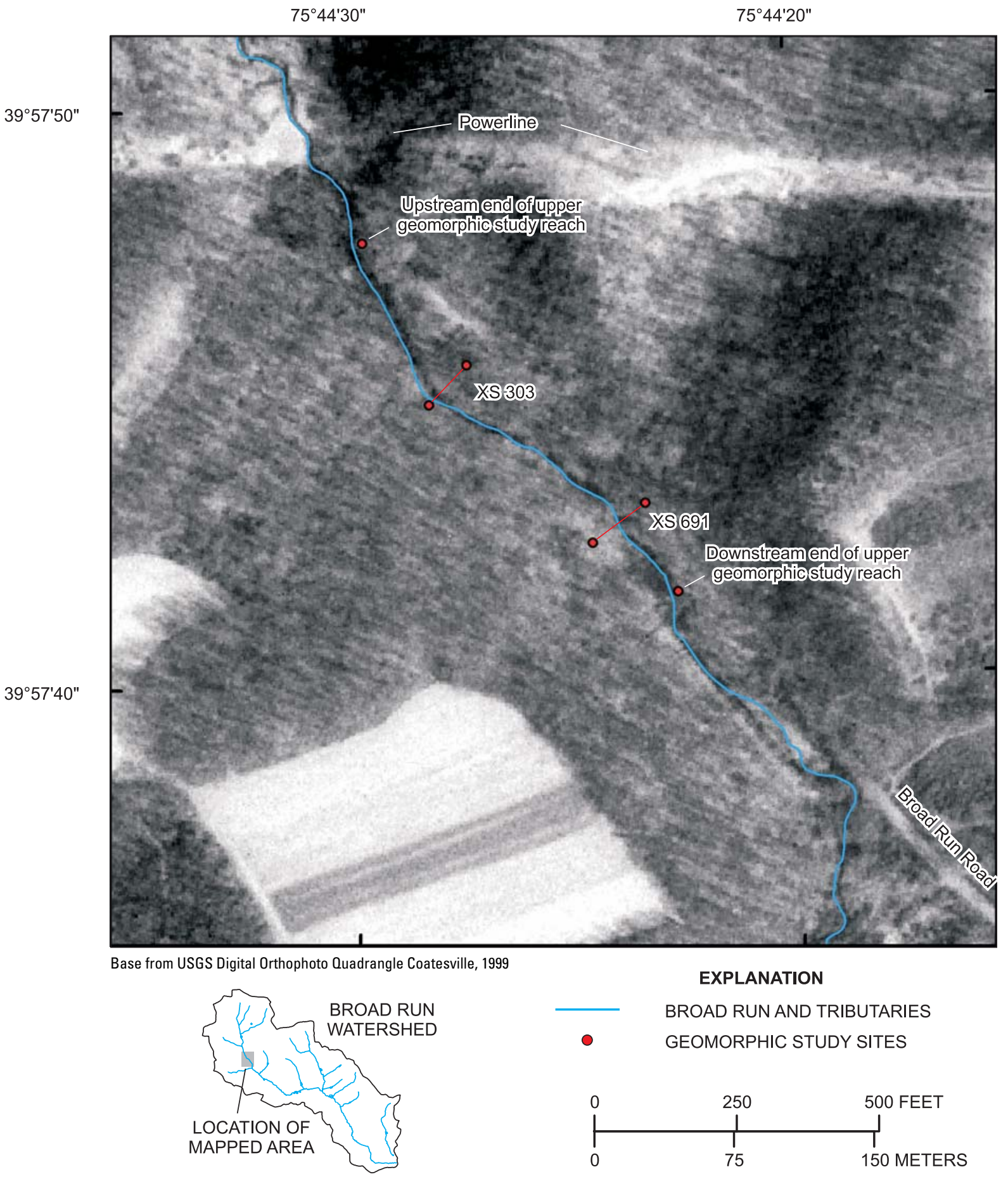

Figure 21. Upper geomorphic study reach on Broad Run, Chester County, southeastern Pennsylvania. 


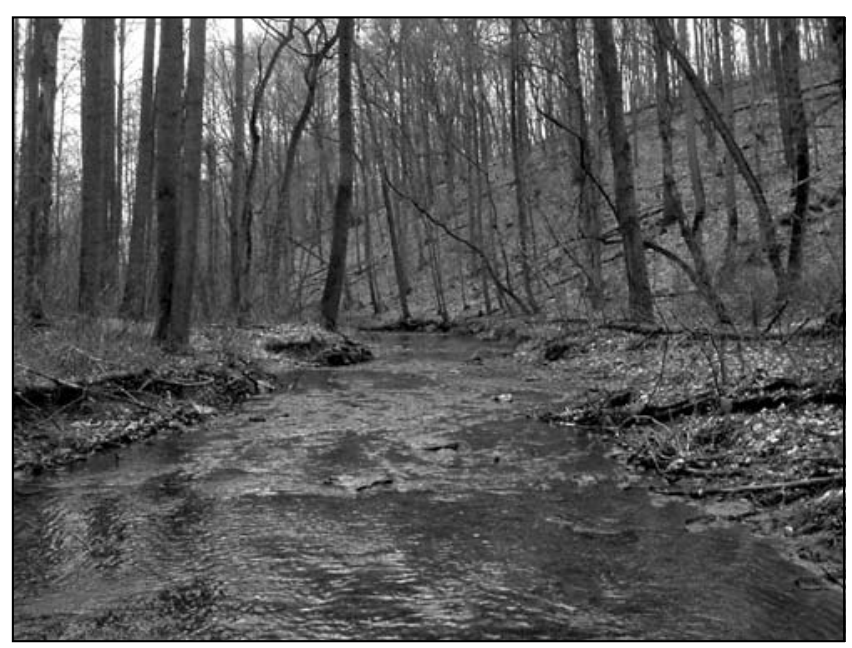

Figure 22. Representative view looking downstream at upper geomorphic study reach on Broad Run, Chester County, southeastern Pennsylvania. (Photograph by P.J. Cinotto, U.S. Geological Survey).

\section{Middle Geomorphic Study Reach}

The middle geomorphic study reach is directly adjacent to Broad Run Road between the intersections with Strasburg and Telegraph Roads (fig. 23). Approximately $4.88 \mathrm{mi}^{2}$ of the Broad Run watershed drains to the reach. This reach lies in a wide valley, exhibiting a flood plain that generally exceeds $300 \mathrm{ft}$ in width, and is dominated by grasses and brush with an occasional stand of deciduous trees (fig. 24). The bankfull channel was well defined throughout this reach and generally was denoted by an abrupt change in bank angle and changes in riparian vegetation. Broad Run in this area is not entrenched and has an available, functioning flood plain to dissipate the forces associated with natural, intermittent flooding (figs. 24 and 25). A large scour hole was found in the streambed approximately $460 \mathrm{ft}$ downstream from the beginning of the reach (fig. 26). Scour holes are the result of localized areas of high-energy water that can erode the larger materials armoring, or paving, the streambed. Scour holes are common around bridges, debris piles, or other objects that cause water velocity to increase and (or) vortices (whirlpools) to form. This specific scour hole was likely a natural occurrence caused by flood water flowing across the flood plain and intersecting the stream channel at a tight bend.

Although natural scour holes can be beneficial in providing habitat complexity for aquatic life, this particular scour hole exposed a vulnerability within this reach of Broad Run. The streambed here is generally well armored, or paved, with an imbricated layer of larger particles (gravels and cobbles) that resist the forces associated with higher flows; however, the materials below this layer are substantially finer, as is evident from the two core samples. The finer material in this reach of stream will likely be more prone to the formation of scour holes if the imbricated layer is breached by high flows.
Scouring is not generally problematic on a stream such as Broad Run provided that (1) the scour does not occur at or near a structure, such as a bridge or pipeline, (2) it is confined to small, localized areas of the streambed, and (3) it occurs in a reach where streamflow and sediment loads are in balance. If these conditions are met, natural recovery on a non-impaired, non-urban stream is usually rapid, and damage to the stream channel and (or) environment will likely be minimal. In effect, such scour holes and (or) local areas of degradation can usually fill in at a sufficient rate and to a sufficient extent that the stream reach never becomes unstable through failing banks and (or) head cutting. The vulnerability, and hence the problem, associated with this type of scouring is that a reduction in sediment loads from upstream or an increase in the magnitude of runoff may not allow the stream to recover quickly enough, or at all, from the scour. An inability to recover would likely lead to excessively high and failing streambanks in relation to the lowered streambed and (or) head cutting as the scour hole becomes a starting point or nick point from which upstream-trending erosion begins. In effect, although excess sediment is often seen as the only problem within a watershed, this reach shows the potential vulnerability of upstream sediment-load reduction and (or) reduction of Broad Run's sediment-transport capacity. Reduction of sediment loads can result from many factors including, but not limited to, development and increase in impervious cover, bridge and road construction, and (or) other processes that "harden" the stream channel or surrounding overbank areas. Reduction of competence (the capacity to transport larger materials through the reach) can result from many factors including, but not limited to, dams, stormwater structures that reduce peak flows, and (or) increased resistance to flow from overgrown upstream riparian areas (as will be discussed in detail below).

While the above noted field observations indicate this reach is potentially vulnerable to future disturbances; data collected within this reach suggest that it is currently in balance with existing runoff and sediment loads. Within the most upstream cross section (115 ft downstream from the upstream end of the middle geomorphic study reach), calculations indicate the stream has the potential to move an estimated 42- to 98$\mathrm{mm}$ particle, whereas the largest particle in a core sample collected from the streambed ( $D i)$ was $135 \mathrm{~mm}$. To move this $135 \mathrm{~mm}$ particle, the estimated mean bankfull water depth required would be $1.5 \mathrm{ft}$, and the estimated bankfull water-surface slope required would be $0.007 \mathrm{ft} / \mathrm{ft}$. The measured mean bankfull water depth was $1.4 \mathrm{ft}$, and the measured bankfull water-surface slope was $0.006 \mathrm{ft} / \mathrm{ft}$. Within the most downstream cross section (569 ft downstream from the upstream end of the reach), the stream has the ability to move an estimated 34to 79-mm particle, whereas the largest particle in a core sample collected from the streambed $(D i)$ was $110 \mathrm{~mm}$. To move this 110 -mm particle, the estimated mean bankfull water depth required would be $2.0 \mathrm{ft}$, and the estimated bankfull water-surface slope required would be $0.007 \mathrm{ft} / \mathrm{ft}$. The measured mean bankfull water depth at this cross section was $1.4 \mathrm{ft}$ and the measured bankfull water-surface slope was $0.005 \mathrm{ft} / \mathrm{ft}$. These 


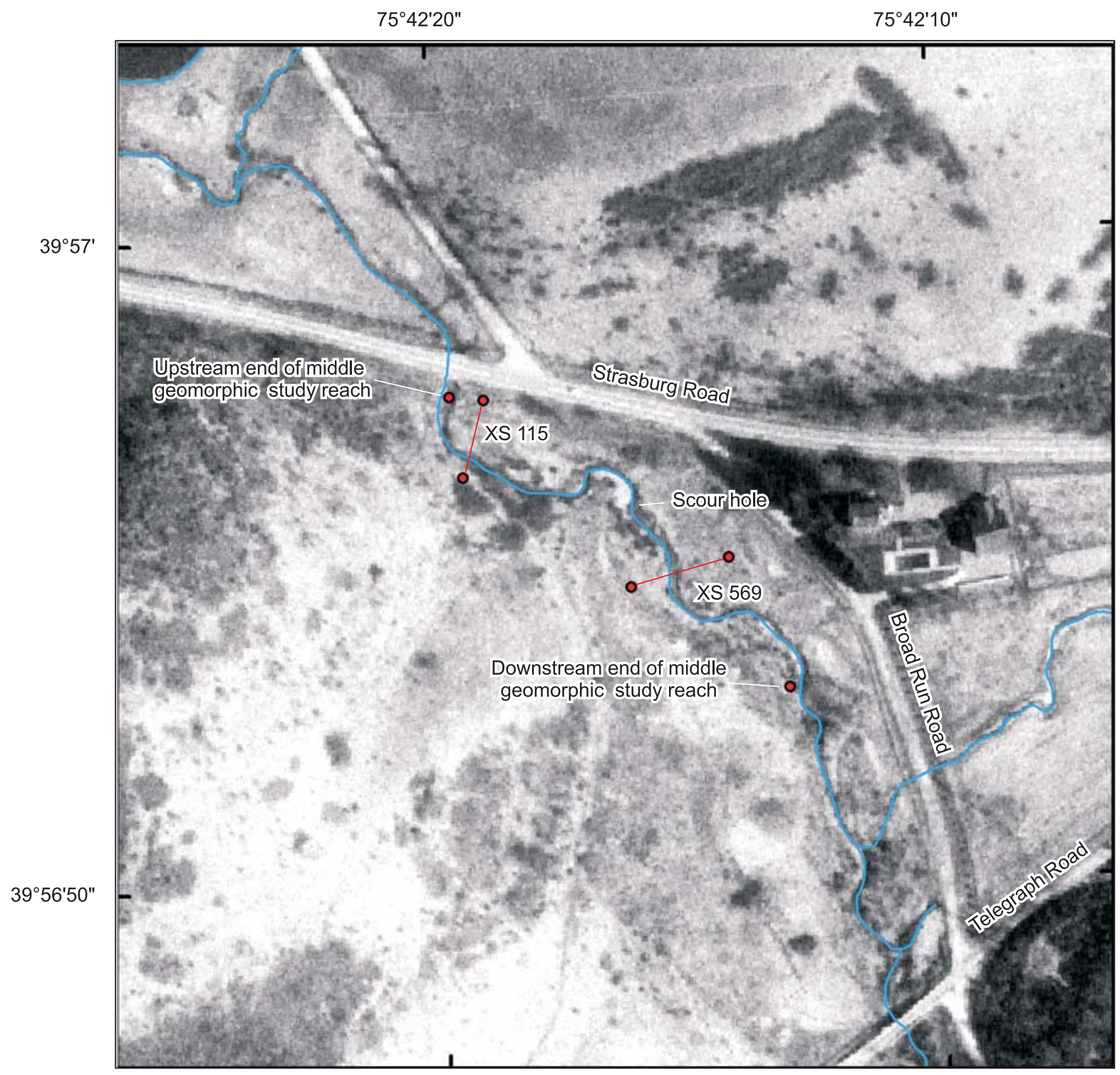

Base from USGS Digital Orthophoto Quardrangle Coatesville, 1999

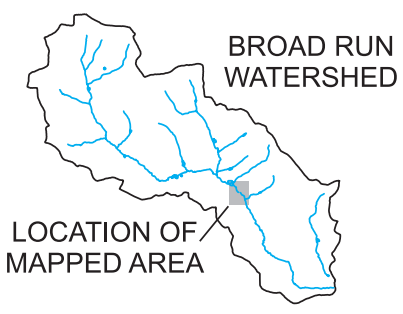

EXPLANATION
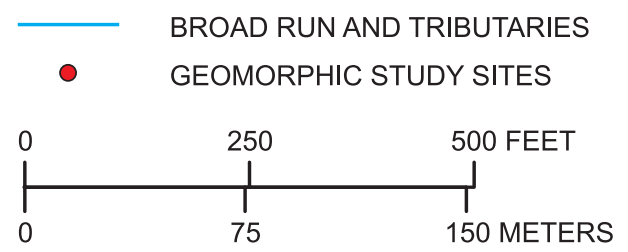

Figure 23. Middle geomorphic study reach on Broad Run, Chester County, southeastern Pennsylvania. 


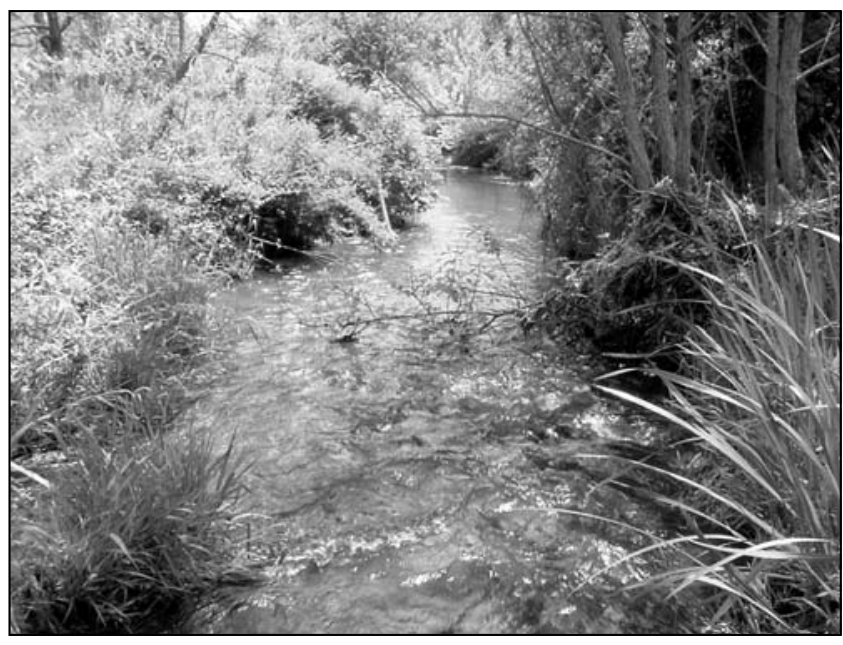

Figure 24. Representative view looking downstream at middle geomorphic study reach on Broad Run, Chester County, southeastern Pennsylvania. (Photograph by P.J. Cinotto, U.S. Geological Survey).

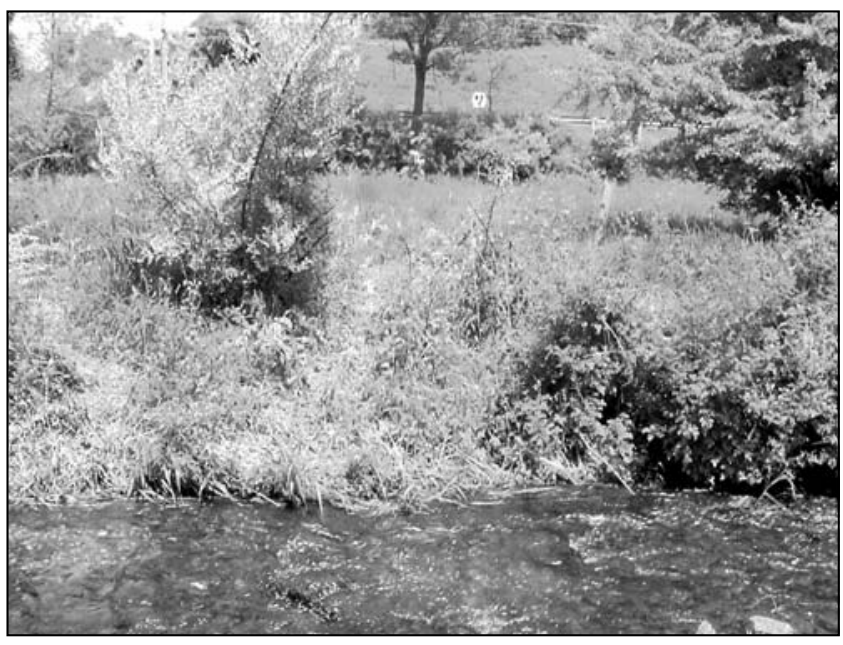

Figure 25. View of left bank and available flood plain, middle geomorphic study reach on Broad Run, Chester County, southeastern Pennsylvania. (Photograph by P.J. Cinotto, U.S. Geological Survey).

data, in conjunction with field observations, indicate that Broad Run within both cross sections (115 and 569) currently lacks the energy required to erode the streambed under bankfull flow. Aggradation within this reach was also considered unlikely because most fine materials are able to be transported through the reach under bankfull flows. For example, the $\mathrm{D}_{84}$ within cross-section 569 was $71.9 \mathrm{~mm}$, within the range of the 34- to 79-mm particle estimated to be mobile under bankfull flows. Although the $\mathrm{D}_{84}$ within cross-section 115 was $110 \mathrm{~mm}$, slightly larger than the 42- to $98-\mathrm{mm}$ particle estimated to be mobile under bankfull flows, these values are close enough given inherent estimation error to indicate that this reach of Broad Run is generally in a state of dynamic equilibrium with the sediment and runoff supplied from upstream in the watershed.

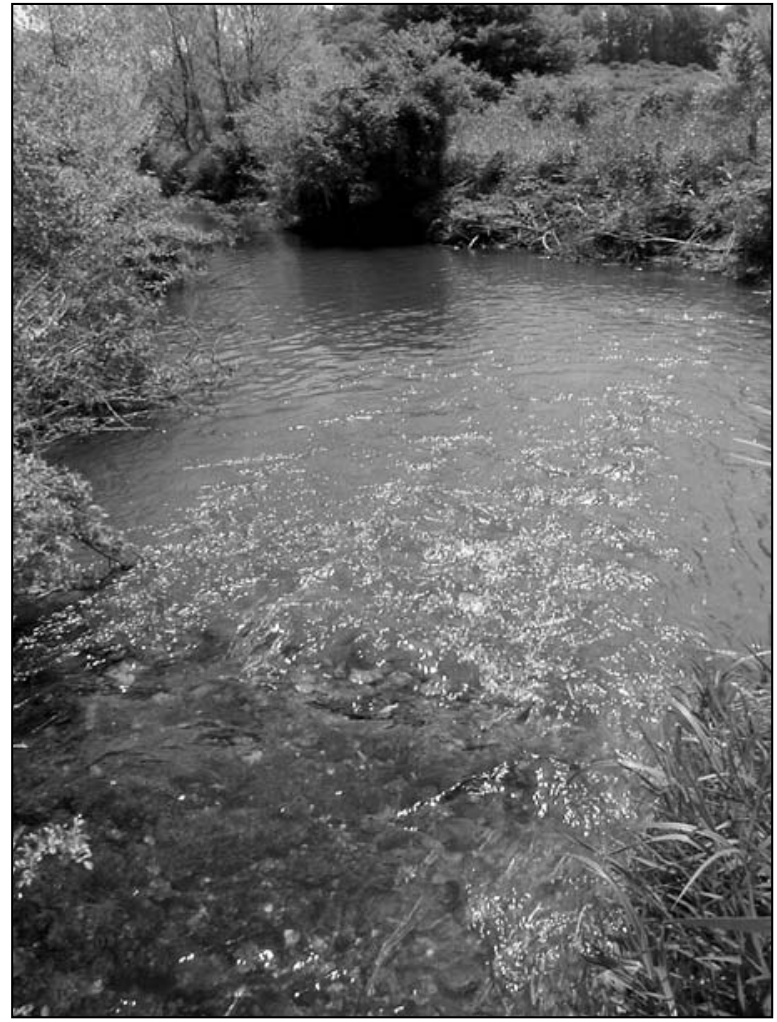

Figure 26. View looking downstream at scour hole in streambed of middle geomorphic study reach on Broad Run, Chester County, southeastern Pennsylvania. (Photograph courtesy of Craig Thomas, Chester County Water Resources Authority, 2003). 


\section{Environmental Setting, Water Budget, and Stream Assessment for the Broad Run Watershed, Chester County, Pa.}

\section{Lower Geomorphic Study Reach}

The lower geomorphic study reach is adjacent to and slightly upstream from USGS streamflow-gaging station 01480638 (Broad Run at Northbrook) (fig. 27). This streamflow-gaging station is just upstream from the bridge carrying Northbrook Road over Broad Run, and approximately $6.39 \mathrm{mi}^{2}$ of the Broad Run watershed drains to it. This lower geomorphic study reach lies in the area where the steeper valley of Broad Run meets the broad, flat flood plain of the West Branch Brandywine Creek. The bankfull channel was well defined throughout this reach and generally was denoted by an abrupt change in bank angle and changes in riparian vegetation. As can be seen in figures 26, 28, and 29, Broad Run is not entrenched; it is characterized by extremely thick riparian vegetation and has an available, functioning flood plain to dissipate the forces associated with natural, intermittent flooding.

The flood plain adjacent to the lower reach is unique to this study area in that it is largely pasture and, thus, offers little resistance to the flow of flood waters across it (actually less than within the stream channel itself); however, before water can enter the flood plain, it must pass through the thick riparian zone that serves as an effective barrier and obstructs the passage of water both within the channel and exiting the channel during higher flows. Because of these features, the stream channel in this reach exhibits several unique characteristics. The extreme resistance to flow resulting from the heavy multiflora rose growth within the riparian zone causes the stream channel to convey only a fraction of the water supplied from upstream; the remainder is stored within the channel as backwater and (or) flows out of the channel, inundating the adjacent flood plain. For example, USGS streamflow-gaging station Broad Run at Northbrook (01480638) yields a measured flow of only approximately $45 \mathrm{ft}^{3} / \mathrm{s}$ at the bankfull stage (relative water elevation when the channel is full), whereas a calculated flow that excludes the effects of the multiflora rose present along the streambanks at the same stage is approximately $160 \mathrm{ft}^{3} / \mathrm{s}$. A bankfull discharge of $160 \mathrm{ft}^{3} / \mathrm{s}$ also agrees more closely with bankfull flows at other streams in the Piedmont Physiographic Province that are not affected by riparian vegetation (Cinotto, 2003).

The water held within the channel by the thick riparian vegetation generally exits the channel to the flood plain with substantial force where riparian vegetation is thin; these areas can often show signs of increased bank erosion known as evulsions. A prominent evulsion was noted approximately $650 \mathrm{ft}$ upstream from the Northbrook Road bridge, on the right bank (fig. 27 and 30). This particular evulsion has also been made more severe by livestock and wildlife that walk through this opening to access the stream (a process called hoof shear). It should be noted that evulsions are simply localized stream reaches that exhibit more severe erosion than the reaches around them; evulsions can have many different causes including natural processes, human and animal activity, or a combination of these activities.
Stream-stage data collected at the adjacent streamflowgaging station also show that this particular stream reach flows out of its banks quite frequently in response to the loss of conveyance; water from Broad Run flowed into the flood plain adjacent to the lower reach 25 times from April 1, 2003, to March 31, 2004, and completely filled the opening of the downstream Northbrook Road culvert approximately 18 times during the same period (fig. 31). When a bridge or culvert opening becomes completely filled with water (up to the lowest structural member), a condition known as pressure flow results that can increase the potential for scour- or erosion-related problems near the bridge. It must be noted here that the structure carrying Northbrook road over Broad Run is not by definition a bridge, but is a precast, reinforced-concrete box culvert designed to look like the historic stone-masonry bridge it replaced (K. Sutow, Pennsylvania Department of Transportation, written commun., 2004). Box culverts are designed to resist scourrelated problems much better than a standard bridge can, especially a stone-masonry bridge, because box-culverts generally have much greater structural integrity and resistance to failure resulting from scour-related structural displacement.

The effects of the dense riparian vegetation on the conveyance of higher flows is apparent when data from Broad Run are compared, by means of flow-duration curves, to data collected at nearby USGS streamflow-gaging stations in Chester County (figs. 32 and 33). Flow-duration curves commonly are used to assess the long-term runoff characteristics of a stream; however, they can be used for short periods of record to compare the response of various streams to runoff during the same time (from April 1, 2003, to March 31, 2004). Flow-duration curves relate streamflows to the statistical probability of a particular streamflow being equaled or exceeded; these curves generally are steeper when streamflows have a higher component of direct runoff and, conversely, flatter when the streamflows are dominated by ground-water discharge or regulated by structures that reduce peak flows (such as dams). The flow-duration curves in figure 32 show that Broad Run has a much flatter slope during high flows ( 0 - to 20-percent exceedence probability) than the other nearby streams in Chester County, Pa., during the same period of record. This flat slope observed for Broad Run during periods of higher flows indicates that Broad Run was subject to unique back-water effects that were not observed at other streamflow-gaging stations within the region and, in effect, shows a natural regulation of Broad Run.

Some additional regulation of higher flows is also likely due to the box culvert carrying Northbrook Road over Broad Run (fig. 27). Because overbank flooding must occur before this structure reaches capacity (fig. 31), and because the culvert does not cause a contraction during lower flows, the box culvert likely does not contribute substantially to initial overbank flooding along the lower geomorphic study reach. However, once this culvert fills completely with water and reaches its capacity to transmit water (pressure flow), the flow of additional flood water will be severely impeded as elevated approach roadways in the flood plain begin to act as a dam. This effect will continue to cause greater depths of flooding 


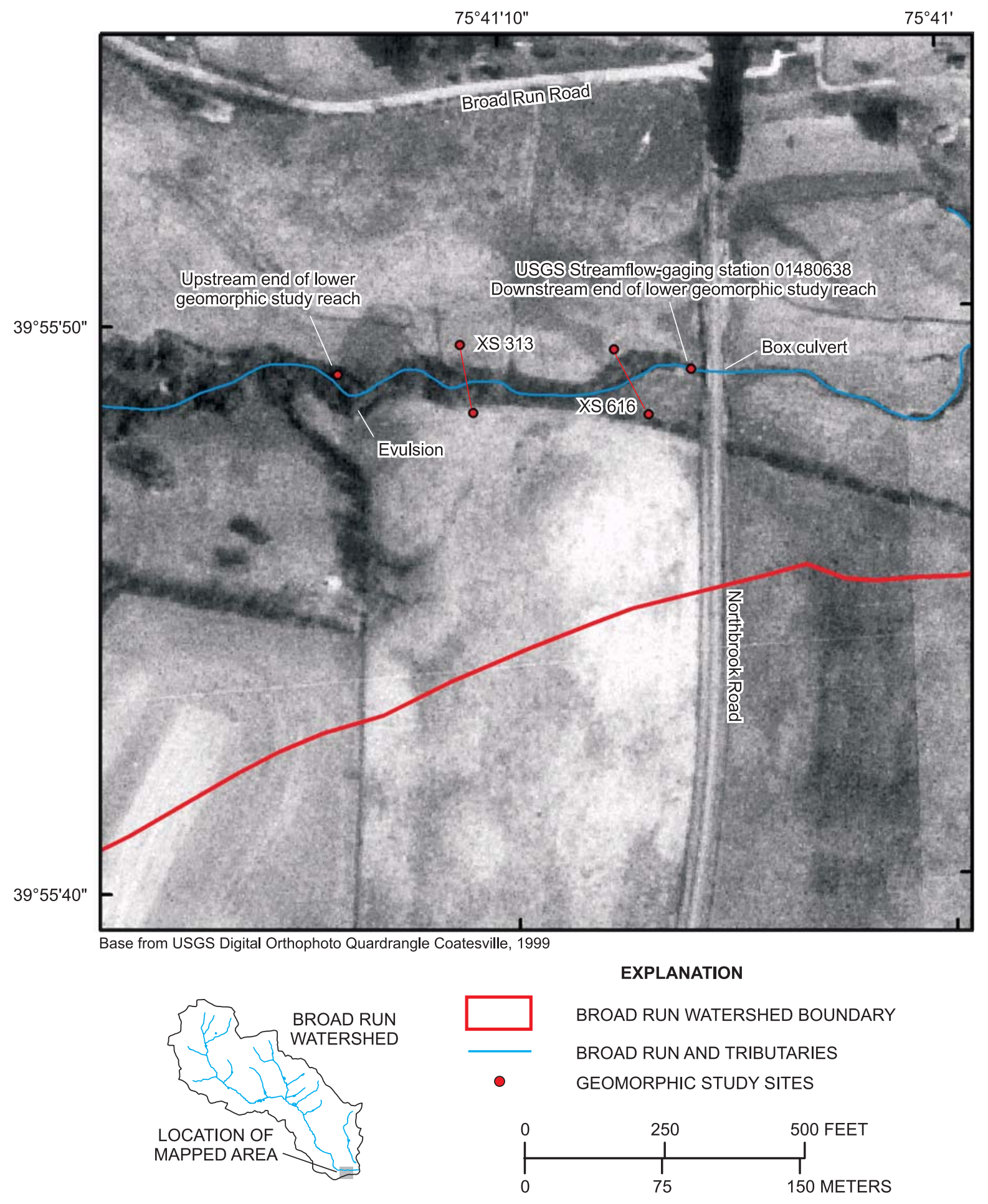

Figure 27. Lower geomorphic study reach on Broad Run, Chester County, southeastern Pennsylvania. 


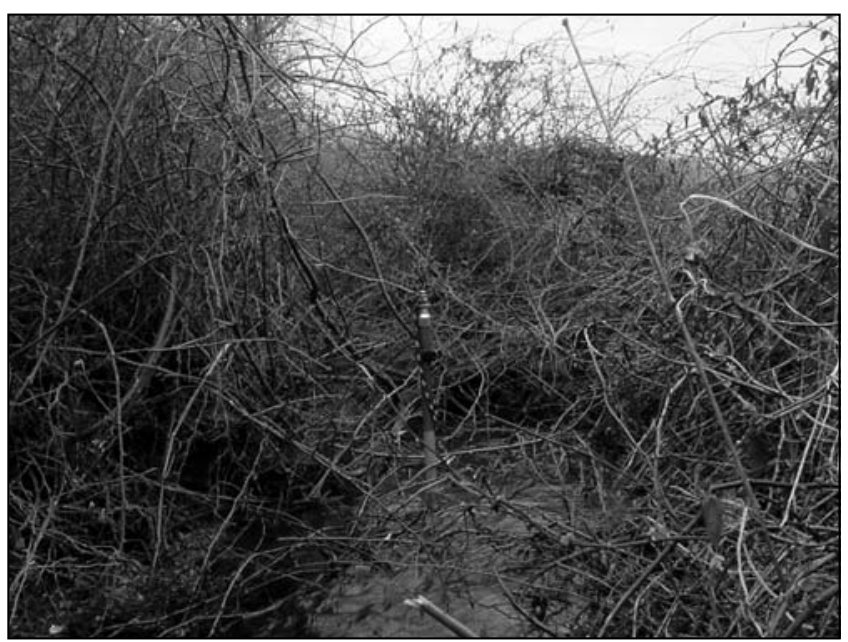

Figure 28. View looking upstream, approximately 100 feet downstream from cross-section 311, on lower geomorphic study reach, Broad Run, Chester County, southeastern Pennsylvania. (Photograph by P.J. Cinotto, U.S. Geological Survey).

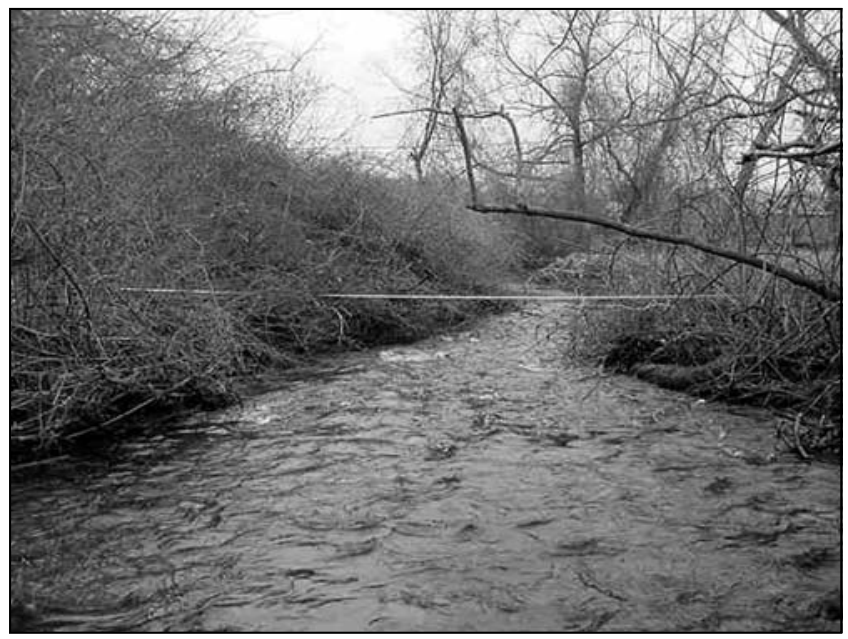

Figure 29. View looking downstream at cross-section 616, just above Northbrook Road, on lower geomorphic study reach, Broad Run, Chester County, southeastern Pennsylvania. (Photograph by P.J. Cinotto, U.S. Geological Survey)

upstream from the culvert until flood waters begin to flow over the roadway; at this point, the effects of the culvert and approach roadways will likely begin to lessen relative to the rest of the stream. This resistance to flow by approach roadways and (or) contracted bridge or culvert openings is common and often results in greater depths of flooding directly upstream from the bridge or culvert. The result is often seen as flatter slopes on a flow-duration curve for high-flow, low-probability events.

Streambed sediments within the heavily vegetated sections of the lower geomorphic study reach were observed to be finer than those within less heavily vegetated reaches of the upper, middle, and lower geomorphic study reaches because of reduction in water velocity required to entrain these sediments and transport them downstream. This finding is important because

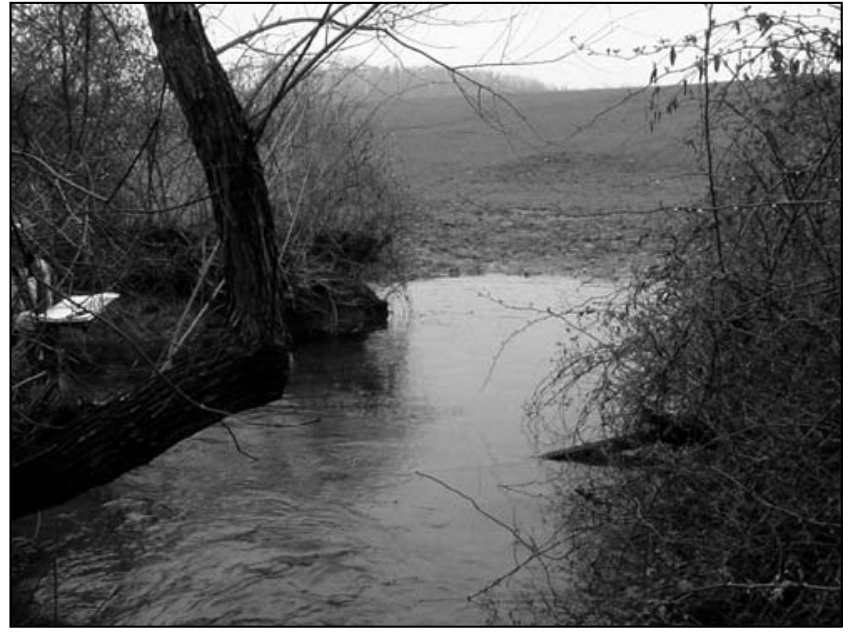

Figure 30. View looking toward right bank, with large evulsion, on lower geomorphic study reach of Broad Run, Chester County, southeastern Pennsylvania. (Photograph by P.J. Cinotto, U.S. Geological Survey).

it indicates that any increased future sediment loads will not likely be able to pass easily through this or other heavily vegetated reaches throughout the watershed. Currently (2003), there are no indications of excessive sediment loads being supplied from upstream within the Broad Run watershed because only small areas of excessive erosion (G-class channels) were observed during mapping of the stream classes, and no downstream reaches were observed to have large accumulations of sediments (such as large sand bars, excessive sediments deposited on the flood plain, and (or) other depositional features). However, if sediment loads are substantially increased (such as by increased numbers of headcuts within the watershed, as discussed earlier), this lower geomorphic study reach would not likely be able, under the current conditions, to transport them. On the basis of these observations, excessive future sediment loads and (or) debris introduced into the stream channel will likely increase future flooding within and adjacent to these reaches and could also cause excessive sedimentation in the overbank areas, potentially damaging property.

Although dense multiflora rose undoubtedly presents a hydraulic problem in regard to conveyance of water through the lower geomorphic study reach, correction of this problem is not without risk. Multiflora rose and similar dense vegetation can be very effective in protecting bank materials from erosion and in reducing velocities within a smaller stream channel. Eradication of multiflora rose along the lower geomorphic study reach may likely achieve less overbank flooding along the reach, but it may also result in rapid channel migration and bank erosion, channel enlargement, and (or) increased sediment loads downstream. 




Figure 31. Water depth at U.S. Geological Survey streamflow-gaging station 01480638 (Broad Run at Northbrook), Chester County, southeastern Pennsylvania, April 1, 2003, to March 31,2004 , showing depth of initial flooding and depth at which downstream box culvert is at full capacity.

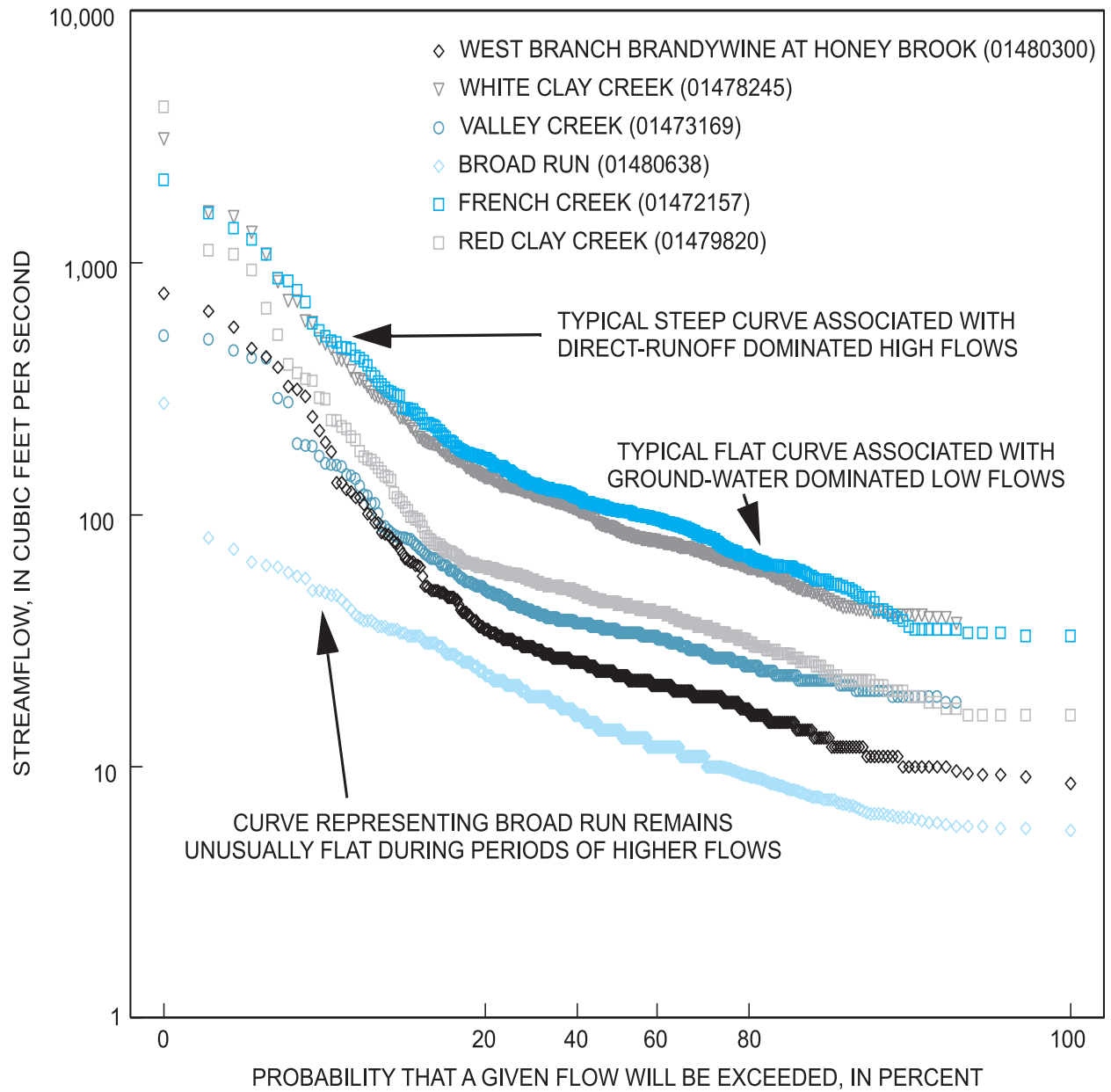

Figure 32. Flow-duration curves for Broad Run and five other regional streams, Chester County, southeastern Pennsylvania. 




Figure 33. Location of U.S. Geological Survey streamflow-gaging stations used for comparison of flow-duration curves, Chester County, southeastern Pennsylvania. 
Data collected within this reach and other data, as described above, suggest the lower geomorphic study reach on Broad Run currently is stable, although unique among the three studied reaches, in its present geomorphic state. Within the most upstream cross section $(311 \mathrm{ft}$ downstream from the upstream end of the lower geomorphic study reach), calculations indicate the stream has the potential to move an estimated 44- to 104-mm particle, whereas the largest particle in a core sample collected from the streambed (Di) was $30 \mathrm{~mm}$. To move this 30-mm particle, the estimated mean bankfull water depth required would be $0.9 \mathrm{ft}$, and the estimated bankfull water-surface slope would be $0.002 \mathrm{ft} / \mathrm{ft}$. The measured mean bankfull water depth at the cross section was $2.1 \mathrm{ft}$, and the measured bankfull water-surface slope was $0.004 \mathrm{ft} / \mathrm{ft}$. Within the most downstream cross section ( $616 \mathrm{ft}$ downstream from the upstream end of the lower geomorphic study reach), the stream has the ability to move an estimated 55 - to $128-\mathrm{mm}$ particle, whereas the largest particle in a core sample collected from the streambed $(D i)$ was $123 \mathrm{~mm}$. To move this $123-\mathrm{mm}$ particle, the estimated mean bankfull water depth required would be $1.7 \mathrm{ft}$, and the estimated bankfull water-surface slope required would be $0.008 \mathrm{ft} / \mathrm{ft}$. The measured mean bankfull water depth at the cross section was $1.5 \mathrm{ft}$, and the measured bankfull water-surface slope was $0.007 \mathrm{ft} / \mathrm{ft}$.

Calculations used to estimate particle entrainment for this study, although standard for this type of analysis, are based on the assumption of open-channel flow and do not take into consideration substantial increases in resistance to flow resulting from dense riparian vegetation, such as the multiflora rose described above. Because multiflora rose has a strong effect on the most upstream cross section of the lower reach (cross-section 313), the large discrepancy between required and measured values required to entrain particles does not necessarily indicate instability. What these data do indicate is that if adjacent multiflora rose growth is removed without accounting for the consequent loss of resistance, velocities will likely increase along this reach, and the stream channel will subsequently possess the energy to entrain larger particles and enlarge the channel.

Data collected at the most downstream cross section of the lower geomorphic study reach (cross-section 616) were similar to data collected at other geomorphic study reaches and reflect the reduced effect of multiflora rose as the stream widens slightly just above the box culvert carrying Northbrook Road over Broad Run (fig. 28). These data indicate similar required and measured values for the entrainment of the $D i$ under bankfull conditions; this relation indicates that the stream is transporting sediment effectively through this reach and does not show current indications of aggradation or degradation of the stream reach.

\section{Limitations}

Any stream assessment based on fluvial geomorphology depends strongly on the correct identification of the bankfull channel; moreover, such an assessment describes the geomor- phic condition of the stream at one specific moment in time. Although regional hydraulic geometry curves were used to minimize the errors in this identification, regional curves were developed from data collected within larger watersheds, making them less effective in identifying of the bankfull channel of smaller tributary drainages of the Broad Run watershed (some as small as 5-10 acres). In these cases, identification of the bankfull channel depended entirely on observation of present geomorphic features. It must also be noted that streams are dynamic natural systems; natural evolution of the stream channel, as well as human influences, such as land-use change, may cause the stream channel to alter its pattern, profile, or dimension over time.

\section{Summary}

Broad Run currently shows no signs of large-scale geomorphic instability and can be considered to be in good condition and in a state of dynamic equilibrium. The streamflow, streambed materials, and associated sediments within the stream channel generally are in balance throughout the watershed, and the stream currently is able to transport the water and sediment provided from upstream without exhibiting accelerated erosion and (or) deposition. However, Broad Run does exhibit signs of vulnerability to future changes within the watershed; such changes could include reduction of flood-plain areas by development and (or) other encroachment, development that could potentially increase the magnitude and (or) duration of stormwater runoff, alterations to current sediment loads, and (or) changes to present riparian areas. These types of future changes may upset the present balance between sediment load, runoff, and the fluvial-geomorphic characteristics of bankfull pattern, profile, and dimension within the Broad Run.

The Broad Run watershed generally was dominated by stream channels with available, functioning floodplains (C -and E- class stream channels) that served to dissipate the energy associated with natural, intermittent flooding. Entrenched stream reaches were isolated among the smaller tributary channels and did not generally appear along the main branch of Broad Run. These entrenched streams were found to result from both anthropogenic (human-influenced) and natural processes.

The presence of an available, functioning flood plain within the Broad Run watershed is conducive to resisting severe streambed and streambank erosion in response to stormflows; this flood plain, consequently, also reduces the sediment loads within Broad Run. Functional flood plains are of great importance in a watershed such as Broad Run where streamflows can be inhibited by thick riparian vegetation and frequently go out of bank. Loss of an available, functioning flood plain within the Broad Run watershed, by such means as development within the floodplain and (or) construction of restrictive road berms at bridge crossings, may cause increased erosion because water flowing through the flood plain must converge at the restriction. Where obstruction of the Broad Run's flood plain is unavoidable, such as the elevated roadway approaches to a bridge, 
structures allowing free passage of water within the flood plain, such as culverts under approach roadways, may reduce contraction scour (accelerated erosion as water is forced through a small opening), straighten flow paths and reduce debris problems within the bridge right-of-way, reduce the magnitude of flooding upstream from the bridge, and allow for balanced sediment transport through the reach.

\section{Stream Quality}

Benthic-macroinvertebrate samples were collected annually in Broad Run between 1999 and 2002 as part of an ongoing USGS stream-monitoring project in cooperation with the Chester County Water Resources Authority and the Chester County Health Department. Benthic macroinvertebrates are aquatic insects, such as mayflies, caddisflies, riffle beetles, and midges, that live on the stream bottom. For example, presence of pollution-tolerant species and absence of sensitive species is indicative of past or intermittent water-quality problems, even if current chemical quality of water is similar to reference conditions. Diversity and community structure of benthic-macroinvertebrate populations can indicate quality of stream waters.

The biologic sampling sites were selected to represent a range of watershed conditions in Broad Run from the headwaters to the confluence with the West Branch Brandywine Creek. Broad Run at Romansville (01480636) is in the upper part of the watershed and has a drainage area of $2.86 \mathrm{mi}^{2}$, Broad Run near Marshallton (0148063750) is near the middle of the watershed and has a drainage area of $5.45 \mathrm{mi}^{2}$, and Broad Run at Northbrook (01480638) is near the lower part of the watershed and had a drainage area of $6.39 \mathrm{mi}^{2}$ (fig. 34). Samples were collected in fall 1999, 2001, and 2002 at the Romansville and Northbrook sites and in fall 2001 and 2002 at the Marshallton site. The sampling location at Northbrook was near the USGS streamflow-gaging station at Northbrook. Taxa and counts for all samples collected are presented in appendix 2 (table 2-1).

Streamflow conditions can have a substantial effect on the chemistry, habitat, and biologic components of a stream reach. Extreme low flows can result in higher water temperatures, decreased dissolved-oxygen levels, and changes in concentrations of chemical constituents. All these factors can cause a shift in the benthic-macroinvertebrate community at a site. High flows can cause physical alteration to the stream bottom that can sometimes affect the benthic-macroinvertebrate community.

A prolonged regional drought followed by flooding related to Hurricane Floyd occurred in 1999 prior to sample collection. These extreme hydrologic events had an effect on stream conditions as evidenced by the chemical, habitat, and biologic data collected in 1999. Hydrologic conditions in 2001 and 2002 were typical of normal flows in the area during October and November (U.S. Geological Survey, 2001, 2002). Streamflows are usually at their lowest in August and September, begin to slightly increase in October and November, and continually rise to their peaks in the spring, after which streamflow begins to decrease through the summer.

\section{Reference Conditions}

Reference sites represent very good or the best available stream quality in a particular area. These sites have stable habitat, good water chemistry, and healthy populations of aquatic organisms. Data from other stream sites with similar watershed characteristics can be compared to that at the reference reach(es) to assess stream quality. Eighteen stream sites were sampled in Chester County between 1999 and 2002 using the same techniques as those used to collect samples in Broad Run (Reif, 2003). These 18 sites were evaluated as possible reference sites for comparison to the Broad Run results. East Branch Brandywine Creek near Glenmoore (station 01480653) was chosen as the reference site because it has a very diverse and healthy benthic-macroinvertebrate community, stable habitat, consistently good chemical quality, similar drainage area, and similar watershed characteristics compared to Broad Run at Northbrook. The East Branch Brandywine Creek site is $10 \mathrm{mi}$ north of Broad Run. Areas minimally affected by human activities are difficult to find in Chester County. Although this site is affected by human activity, including low-level agricultural activities, it represents the best available stream quality in the area to use in a comparison with Broad Run. Chemical and benthic-macroinvertebrate data from the reference site (East Branch Brandywine Creek near Glenmoore, station 01480653) are published in the USGS annual water-data reports for Pennsylvania (U.S. Geological Survey, 1999-2003)

\section{Stream Quality of Broad Run}

Water-quality samples were collected in conjunction with the biologic samples and were analyzed for concentrations of nutrients, major ions, and metals. Data also were collected to evaluate the physical habitat at each sampling location. By examining the biologic, water chemistry, and habitat conditions together, overall stream quality can be evaluated.

\section{Water Chemistry}

Nitrogen and phosphorus are micronutrients needed for plant (and algae) growth. They naturally occur in water at low concentrations, however, increased concentrations may be associated with human activities. Anthropogenic sources include commercial fertilizers and manure, wastewater-treatment-plant discharges, leachate from on-site sewage disposal systems, and atmospheric deposition. Concentrations of nutrients above natural background levels can cause increased plant and algae growth, which can result in decreased benthic-macroinvertebrate diversity (Buck and others, 2000). Other factors, such as water temperature and the amount of sunlight reaching the stream, also contribute to nuisance plant growth. 


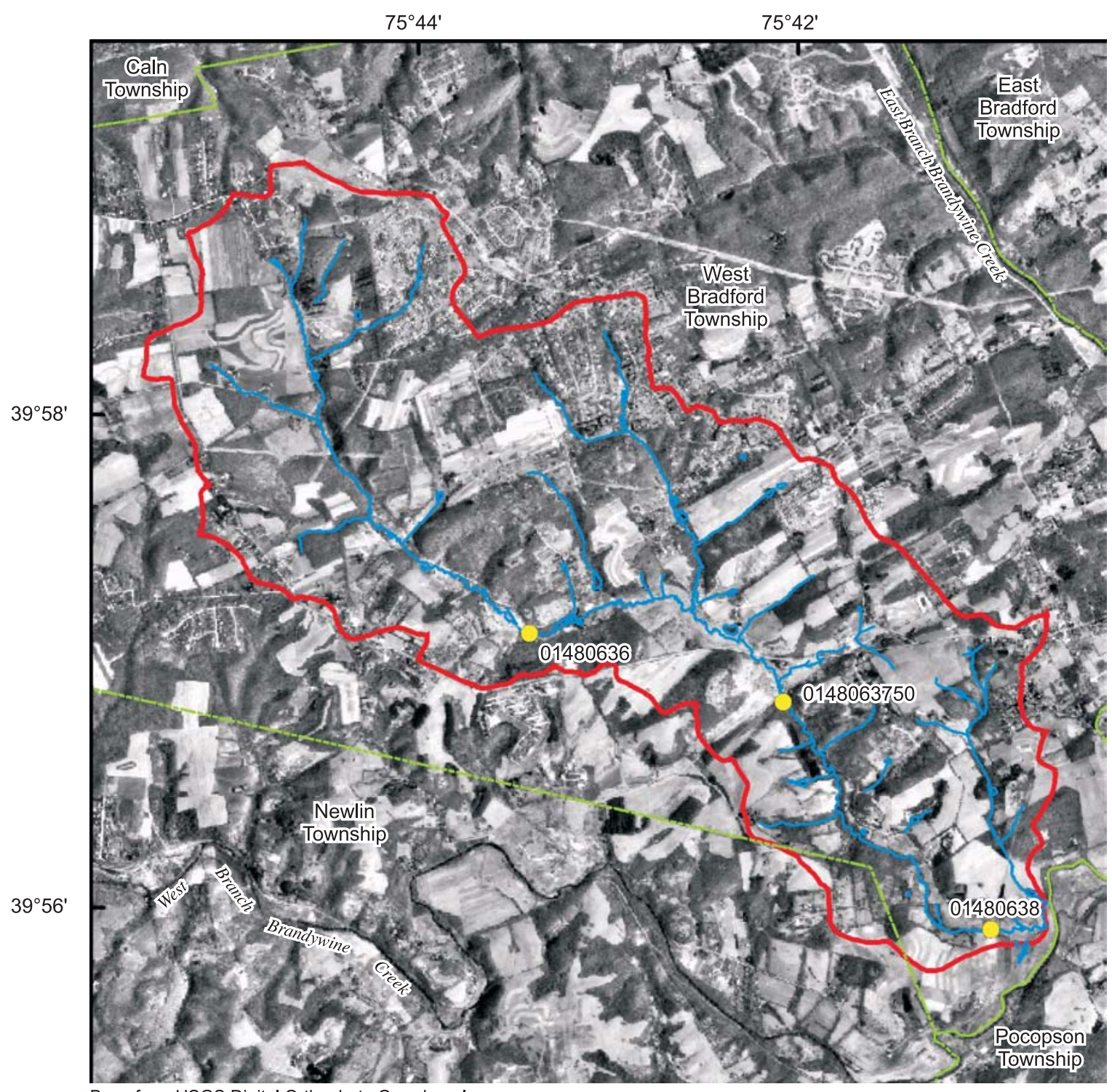

Base from USGS Digital Orthophoto Quardrangle

Coatesville, 1999 and Unionville, 1999

\section{EXPLANATION}

BROAD RUN WATERSHED

TOWNSHIP BOUNDARY

BROAD RUN AND TRIBUTARIES

01480638 BIOLOGICAL STUDY SITES AND IDENTIFIER

Figure 34. Locations of biologic study sites within the Broad Run watershed, Chester County, southeastern Pennsylvania. 
Boron can be used as a conservative tracer of wastewater because of its high solubility and its insensitivity to evaporation, volatilization, and oxidation reduction reactions (Vengosh, 1998; Pitt and others, 2000). Natural background concentrations of boron in Chester County generally are $30 \mu \mathrm{g} / \mathrm{L}$ or less (Sloto, 1987). Concentrations of boron above the natural background concentrations may be associated with wastewater discharges. Metals and trace elements in small quantities are needed for normal plant and animal development. However, some metals and trace elements, such as mercury and arsenic, can be toxic at relatively low concentrations (Meade, 1995).

Metals and trace elements in stream samples come from natural as well as arthropogenic sources. Naturally occurring sources are from rock weathering, soil erosion, and the dissolution of salts. Arthropogenic sources include wastewater discharges, industrial activities, mining, and agriculture.

Samples for nutrients, metals, trace elements, and fieldchemical characteristics (such as temperature and $\mathrm{pH}$ ) were collected at all stream sites, and all data are presented in appendix 2 (table 2-2).

Water temperature, $\mathrm{pH}$, dissolved oxygen, and specific conductance measured at the time of collection were similar to reference conditions for the area and were sufficient to support a healthy biologic community. Water temperature ranged between 5.4 and $10^{\circ} \mathrm{C}, \mathrm{pH}$ ranged between 6.8 and 7.4 standard units, dissolved-oxygen concentration ranged between 10.1 and $12.2 \mathrm{mg} / \mathrm{L}$, and specific conductance ranged between 188 and $231 \mu \mathrm{S} / \mathrm{cm}$. Nitrate concentrations from the samples collected at the three sites in Broad Run ranged between 2.08 and $2.81 \mathrm{mg} / \mathrm{L}$. These concentrations are higher than the average concentrations measured at the reference site $(1.00 \mathrm{mg} / \mathrm{L})$, but are below the average concentration of all the sites sampled in the Chester County stream-monitoring project between 1999 and $2001(3.40 \mathrm{mg} / \mathrm{L})$. Orthophosphate and ammonia concentrations were below the analytical detection limit of $0.04 \mathrm{mg} / \mathrm{L}$. This combination of relatively low nitrate concentrations and low orthophosphate concentrations will not support excessive aquatic plant growth. Concentrations of chloride from the samples collected at the three sites in Broad Run ranged between 17.9 and $22.6 \mathrm{mg} / \mathrm{L}$. These concentrations were greater than the average chloride concentration of $12.6 \mathrm{mg} / \mathrm{L}$ measured at the reference site between 1999 and 2001. All other major ion concentrations were similar to concentrations measured at the reference site, and metal concentrations were near or below the analytical detection limit. Boron concentrations were variable but were generally at or slightly above the background concentration of $30 \mu \mathrm{g} / \mathrm{L}$ indicating no major source of wastewater in the Broad Run watershed. On the basis of the chemical samples collected, the water quality in Broad Run is similar to reference conditions for the area and is sufficient to support a healthy biologic community.

\section{Habitat}

All sites sampled in the Broad Run watershed were in areas of low-density residential land use with numerous field/ pasture and wooded areas. Stream widths of the active, or wetted, channel (not the bankfull channel as described previously) ranged from approximately $4.5 \mathrm{ft}$ at Romansville to $15 \mathrm{ft}$ at Northbrook, and mean stream depth was approximately $0.5 \mathrm{ft}$ at all sites. The sites were partially or fully shaded, and all sampling reaches were $300 \mathrm{ft}$ in length. Each sampling reach consisted of small cobble-dominated riffles on a sand and gravel substrate. Algae cover and sedimentation were light to moderate at all sites. The riparian areas were wide and contained trees and multiflora rose, along with some horse pasture. Minor bank erosion was evident at each site.

The habitat assessments of Broad Run at Romansville (01480636) identified minor bank erosion and unstable bottom habitat as the most important habitat issues. The riffles in the reach were dominated by gravel and sand that provide limited available habitat for benthic-macroinvertebrate colonization.

The habitat assessments of Broad Run at Marshallton (014806750) and Broad Run at Northbrook (01480638) identified minor sedimentation as the most significant habitat issue. The two downstream sites had better developed and more stable riffles, which provide better habitat for macroinvertebrates.

\section{Benthic Macroinvertebrates}

The biologic samples collected from Broad Run contained a diverse benthic-macroinvertebrate community dominated by pollution-intolerant and intermediate taxa (taxa that are intermediate in their pollution tolerance), including mayflies, stoneflies, and caddisflies. Benthic-macroinvertebrate community structure was relatively similar in all the samples collected at the three stream sites. The total number of taxa collected ranged between 35 and 46, and the total EPT taxa ranged between 16 and 24 in Broad Run (table 9). The numbers of taxa and EPT taxa collected in 1999, 2001, and 2002 at the reference site (East Branch Brandywine near Glenmoore) were similar to those collected in Broad Run (table 9). Broad Run HBI values calculated from benthic-macroinvertebrate data ranged from 3.68 to 5.10; the median value was 4.35 , which indicates low to moderate organic enrichment. Organisms with an HBI tolerance value of 4 or less ("pollution intolerant"; Klemm and others, 1990) made up 14 to 32 percent of the individuals collected. The most dominant organisms in the benthic-macroinvertebrate communities were hydropsychid caddisflies, elmid beetles, and Chironomidae (midges)(appendix 2-1). All these groups are intermediate in their pollution tolerance. Organisms with an HBI tolerance value of 6 or more ("pollution tolerant"; Klemm and others, 1990) made up 0.1 to 4.8 percent of the individuals collected.

The high number of total taxa and EPT taxa collected from Broad Run, along with the high percentage of pollution-intolerant organisms and low percentage of pollution-tolerant organisms (table 9), is an indication that the benthic-macroinverte- 
Table 9. Summary of total taxa; Ephemeroptera, Plecoptera, and Trichoptera (EPT) taxa richness; and Hilsenhoff Biotic Index (HBI) values for benthic-macroinvertebrates samples collected from Broad Run, Chester County, Pa., 1999-2002.

[>, greater than; <, less than]

\begin{tabular}{|c|c|c|c|c|c|c|c|c|}
\hline $\begin{array}{c}\text { U.S. Geological } \\
\text { Survey } \\
\text { identification } \\
\text { number }\end{array}$ & Station name & $\begin{array}{l}\text { Drainage } \\
\text { area }\end{array}$ & Date & $\begin{array}{l}\text { Total } \\
\text { taxa }\end{array}$ & $\begin{array}{c}\text { EPT } \\
\text { taxa } \\
\text { richness }\end{array}$ & $\begin{array}{c}\text { Percent } \\
\text { intolerant } \\
(\mathrm{HBI}>4)\end{array}$ & $\begin{array}{l}\text { Percent } \\
\text { tolerant } \\
(\mathrm{HBI}<6)\end{array}$ & $\mathrm{HBI}$ \\
\hline \multirow[t]{3}{*}{01480636} & \multirow{3}{*}{$\begin{array}{l}\text { Broad Run at Romansville, Pa. } \\
\text { (Lat } 39^{\circ} 57^{\prime} 06^{\prime} \text { Long } 75^{\circ} 43^{\prime} 33^{\prime \prime} \text { ) }\end{array}$} & \multirow[t]{3}{*}{2.86} & $11 / 09 / 1999$ & 43 & 21 & 13.8 & 4.8 & 5.10 \\
\hline & & & $10 / 29 / 2001$ & 43 & 19 & 32.7 & .1 & 3.68 \\
\hline & & & $12 / 17 / 2002$ & 45 & 23 & 28.3 & .8 & 4.37 \\
\hline 0148063750 & $\begin{array}{l}\text { Broad Run near Marshallton, Pa. } \\
\left.\text { (Lat } 39^{\circ} 56^{\prime} 48^{\prime \prime} \text { Long } 75^{\circ} 42^{\prime} 11^{\prime \prime}\right)\end{array}$ & 5.45 & $12 / 17 / 2002$ & 46 & 22 & 24.3 & .6 & 4.08 \\
\hline \multirow[t]{3}{*}{01480638} & \multirow{3}{*}{$\begin{array}{l}\text { Broad Run at Northbrook, Pa. } \\
\left.\text { (Lat } 39^{\circ} 55^{\prime} 49^{\prime} \text { Long } 75^{\circ} 46^{\prime} 44^{\prime \prime}\right)\end{array}$} & \multirow[t]{3}{*}{6.39} & 11/09/1999 & 35 & 16 & 13.8 & 3.0 & 4.30 \\
\hline & & & $10 / 29 / 2001$ & 41 & 20 & 17.3 & 2.9 & 4.50 \\
\hline & & & $11 / 26 / 2002$ & 45 & 24 & 14.8 & 4.0 & 4.49 \\
\hline
\end{tabular}

brate community in Broad Run is being minimally affected by water quality and instream habitat conditions. The HBI values from samples collected also indicate minimally affected water quality and instream habitat conditions.

Although the benthic-macroinvertebrate communities collected at all three sites in the Broad Run watershed were indicative of good overall conditions, there were some small differences between sites and years. The site at Romansville had a more variable benthic-macroinvertebrate community compared to the two downstream sites (table 9). The numbers of taxa and EPT taxa were stable over the 3 years, but the number of individuals collected within each taxon was highly variable. This variability may be due to seasonal differences, effects of flooding, or unstable physical habitat conditions at the Romansville site. The benthic-macroinvertebrate communities identified from all the Marshallton and Northbrook samples were similar in community structure.

\section{Summary}

Chemical, habitat, and benthic-macroinvertebrate data collected from three stream sites in the Broad Run watershed indicate good stream quality. Chemical data indicated that nutrient, ion, and metal concentrations are similar to those at a nearby reference stream. Overall habitat conditions were stable throughout the entire watershed. Limited stream-bottom habitat was the lowest rated habitat category at the headwater site, and sedimentation was the lowest rated category at the downstream sites. Biologic samples indicate diverse and healthy benthicmacroinvertebrate communities throughout the entire Broad Run watershed. Benthic-macroinvertebrate communities were dominated by taxa that were intolerant or moderately tolerant to pollution. A few individuals from pollution-tolerant taxa were also present within some samples, but they represented few taxa and individuals. In general, data from all samples indicate that the overall stream quality of the Broad Run is sufficient to support a healthy biologic community. 


\section{Conclusions and Implications for Land-Use Management}

Broad Run currently exhibits generally stable fluvial geomorphic characteristics (pattern, profile, and dimension of the stream channel), has healthy biologic communities within the stream, and does not appear to be greatly affected by commercial or residential water use within the watershed. Geomorphic data have shown, however, that the Broad Run is sensitive - and, therefore, vulnerable - to future changes in land use and (or) land cover within the watershed that may upset either the balance between sediment loads and runoff supplied from upstream or the fluvial geomorphic characteristics of the stream channel. If Broad Run becomes unbalanced or degraded in terms of fluvial geomorphology, the habitat within Broad Run may also become reduced or degraded, and reduced biologic diversity may result.

Broad Run, like all streams, is a complex natural system that will respond literally to every change, no matter how small, within its drainage. Development within the Broad Run watershed and consequent changes to the runoff characteristics have been shown to cause entrenched channels among small tributaries to Broad Run; if such problems associated with land use in the watershed are allowed to increase in number and (or) size of impaired areas, Broad Run will likely become unbalanced in terms of sediment load and runoff. This imbalance will likely cause changes in the stream-channel morphology, degrade the biodiversity of the stream, and reduce the overall health of Broad Run.

Changes in runoff magnitude or duration of streamflows by stormwater structures, increases in the amount of impervious surface within the watershed, increases or decreases in sediment supplied to Broad Run by accelerated erosion and (or) addition of hardened surfaces, encroachment by development onto flood-plain areas, and (or) destruction of riparian areas are examples of changes that may result in severe streambank and streambed erosion, destruction of habitat, increased scour, downstream sedimentation, and (or) more frequent flooding. Proper management of the current resources and responsible future growth, along with frequent monitoring, may maintain a stable, healthy Broad Run watershed well into the future.

\section{Acknowledgments}

The cooperation of the Chester County Water Resources Authority, the Chester County Health Department, West Bradford Township, and the residents of the Broad Run watershed are gratefully acknowledged. The authors thank the Page and Powell families for allowing access and placement of instrumentation on their properties and the Tattersall Golf Club and Highland Orchards for allowing access to their properties and water-use records.

\section{References Cited}

Andrews, E.D., 1984, Bed-material entrainment and hydraulic geometry of gravel-bed rivers in Colorado: Geological Society of America, Bulletin 95, p. 371-378.

Barbour, M.T., Gerritsen, J., Snyder, B.D., Stribling, J.B., 1999, Rapid bioassessment protocols for use in streams and rivers-Periphyton, benthic macroinvertebrates and fish (2d ed): Washington D.C., Office of Water Regulations and Standards, U.S. Environmental Protection Agency, EPA/841/B-99/002 [various pagings].

Barnes, H.H., Jr., 1967, Roughness characteristics of natural channels: U.S. Geological Survey Water-Supply Paper $1849,213 \mathrm{p}$.

Berg, T.M., McInerney, M.K., Way, J.H., and MacLachlan, D.B., 1983, Stratigraphic correlation chart of Pennsylvania: Commonwealth of Pennsylvania, Department of Environmental Resources, Office of Resources Management, Bureau of Topographic and Geologic Survey, General Geology Report 75, 1 p.

Bode, R.W., 1991, Quality assurance work plan for biological stream monitoring in New York State: New York Department of Environmental Conservation Technical Report, 79 p.

Buck, S., Dodds, W., Fisher, J., Hart, D., Parker, A., Stevenson, J., Watson, V., and Welch, E., 2000, Nutrient criteria technical guidance manual-Rivers and streams: U.S. Environmental Protection Agency, EPA-822-B-00-002, 152 p.

Chester County Planning Commission, 1991, Water facilities inventory, 1991-Community facilities update, Chester County, Pennsylvania: West Chester, Pa., Chester County Planning Commission.

Chester County Water Resources Authority, Chester County Planning Commission, Camp Dresser \& McKee, and Gaadt Perspectives LLC, 2001, Chester County, Pennsylvania water resources compendium part 1 and part 2, December 2001: West Chester, Pa., Chester County Water Resources Authority, CD-ROM.

Cinotto, 2003, Development of regional curves of bankfullchannel geometry and discharge for streams in the nonurban, Piedmont Physiographic Province, Pennsylvania and Maryland: U.S. Geological Survey Water-Resources Investigations Report 03-4014, 27 p.

Dunne, T., and Leopold, L.B., 1978, Water in environmental planning: San Francisco, Calif., W.H. Freeman, 818 p.

Fishman, M.J., and Friedman, L.C., 1989, eds., Methods for determination of inorganic substances in water and fluvial sediments: U.S. Geological Survey Techniques of WaterResources Investigations, book 5, chap. A1, 545 p.

Gordon, N.D., McMahon, T.A., and Finlayson, B.L., 1992, Stream hydrology, an introduction for ecologist: West Sussex, England, John Wiley and Sons, 526 p.

Hilsenhoff., W.L. 1982, Using a biotic index to evaluate water quality in streams: Wisconsin Department of Natural Resources Technical Bulletin 132, 22 p. 
Klemm, D.J., Lewis, P.A., Fulk, Florence, and Lazorchick, J.M., 1990, Macroinvertebrate field and laboratory methods for evaluating the biological integrity of surface waters: U.S. Environmental Protection Agency, EPA/600/4-90/030, $256 \mathrm{p}$.

Kochanov, W.E., 2004, Sinkhole inventory and online database: Pennsylvania Department of Conservation and Natural Resources, accessed Oct. 22, 2004, at http:// www.dcnr.state.pa.us/topogeo/hazards/sinkholes.aspx.

Lyttle, P.T., and Epstein, J.B., 1987, Geologic map of the Newark $1^{\circ} X 2^{\circ}$ quadrangle, New Jersey, Pennsylvania, and New York: U.S. Geological Survey Miscellaneous Investigations Series Map I-1715, 2 pls., scale 1:250,000.

McGreevy, L.J., and Sloto, R.A., 1980, Development of a digital model of ground-water flow in deeply weathered crystalline rock, Chester County, Pennsylvania: U.S. Geological Survey Water-Resources Investigations Report 80-2, 42 p.

Meade, R.H., ed., 1995, Contaminants in the Mississippi River, 1987-92: U.S. Geological Survey Circular 1133, 140 p.

Merritt, R.W., and Cummins, K.W., eds., 1996, An introduction to the aquatic insects of North America ( $3 \mathrm{~d}$ ed.): Dubuque, Iowa, Kendall Hunt Publishing Company, 862 p.

Pitt, R., Lalor, M., Harper, J., Nix, C., and Barbe, D., 2000, Potential new tools for the use of tracers to indicate sources of contaminants to storm drainage systems: U.S. Environmental Protection Agency, EPA-625/R00/001, variously paginated.

Rantz, S.E., and others, 1982, Measurement and computation of streamflow, volumes 1 and 2: U.S. Geological Survey WaterSupply Paper 2175, $631 \mathrm{p}$.

Reif, A.G., 2002, Assessment of stream conditions and trends in biological and water-chemistry data from selected streams in Chester County, Pennsylvania, 1981-1997: U.S. Geological Survey Water-Resources Investigations Report 02-4242, $77 \mathrm{p}$.

Reif, A.G., 2003, Assessment of water chemistry, habitat, and benthic macroinvertebrates at selected stream-quality monitoring sites in Chester County, Pennsylvania, 1998-2000: U.S. Geological Survey Open-File Report 03-499, 93 p.

Rosgen, D.L., 1996, Applied river morphology: Minneapolis, Minn., Printed Media Companies, 352 p.

Rosgen, D.L., 1998, The reference reach field book: Pagosa Springs, Colo., Wildland Hydrology, 210 p.

Rosgen, D.L., 2002, River assessment and monitoring, August 2002, field guide: Pagosa Springs, Colo., Wildland Hydrology, [various pagings].

Schreffler, C.L., 1998, Low-flow statistics of selected streams in Chester County, Pennsylvania: U.S. Geological Survey Water-Resources Investigations Report 98-4117, 43 p.

Sevon, W.D., comp., 2000, Physiographic provinces of Pennsylvania (4th ed.): Pennsylvania Geologic Survey, map 13, scale 1:2,000,000, accessed Oct. 24, 2000, at http://www.dcnr.state.pa.us/topogeo/map13/13pls.htm.

Shields, A.F., 1936, Anwendung der Ahnlickeit-mechanik und der Turbulenzforschung auf die Geschiebelerwegung. Mittei- lungen der Preussischen Versuchsanstalt fur Wasserbau und Schiffbau: Berlin, Germany, 26 p.

Simon, A., 1989, A model of channel response in disturbed alluvial channels: Earth Surface Processes and Landforms, v. 14 , no. 1, p. 11-26.

Sloto, R.A., 1987, Effect of urbanization on the water resources of eastern Chester County, Pennsylvania: U.S. Geological Survey Water-Resources Investigations Report 87-4098, $131 \mathrm{p}$.

Sloto, R.A., 1990, Geohydrology and simulation of groundwater flow in the carbonate rocks of the Valley Creek Basin, Eastern Chester County, Pennsylvania: U.S. Geological Survey Water-Resources Investigations Report 89-4169, $60 \mathrm{p}$.

Sloto, R.A., 1994, Geology, hydrology, and ground-water quality of Chester County, Pennsylvania: Chester County Water Resources Authority, Water-Resource Report 2, 127 p.

Sloto, R.A., and Crouse, M.Y., 1996, HYSEP-A computer program for streamflow hydrograph separation and analysis: U.S. Geological Survey Water-Resources Investigations Report 96-4040, 46 p.

U.S. Department of Agriculture, 1963, Soil survey, Chester and Delaware Counties, Pennsylvania: U.S. Department of Agriculture Series 1959, no. 19, 124 p.

U.S. Department of Agriculture, 1994, State soil geographic data base (STATSGO), accessed November 19, 2004, at http://www.ncgc.nrcs.usda.gov/branch/ssb/products/ statsgo/data/pa.html.

U.S. Department of Agriculture, 2004, Official soil series descriptions, accessed November 19, 2004, at http://soils.usda.gov/technical/classification/osd/index.html.

U.S. Department of Commerce, 2003-04, Climatological data for Pennsylvania, National Oceanic and Atmospheric Administration, National Environmental Satellite, Data, and Information Service, Northeast Regional Climate Center, accessed April 27, 2004, at http://climod.nrcc.cornell.edu/ index_html.

U.S. Geological Survey, 1996, National land cover data: U.S. Geological Survey, accessed November 10, 2004, at http://landcover.usgs.gov/nationallandcover.asp.

U.S. Geological Survey, 1999-2003, Water resources data, Pennsylvania, 1998-2002-Volume 1: U.S. Geological Survey Water Data Reports PA-98-1 to PA-02-1 (published annually).

Vengosh, A., 1998, The isotopic composition of anthropogenic boron and its potential impact on the environment: Biological Trace Element Research, v. 66, no. 1-3, p. 145-151.

Wershaw, R.L., Fishman, M.J., Grabbe, R.R., and Lowe, L.E., eds., 1987, Methods for determination of organic substances in water and fluvial sediments: U.S. Geological Survey Techniques of Water-Resources Investigations, book 5, chap. A3, 80 p.

West Bradford Township, 2004, West Bradford Township history and demographics, accessed January 23, 2004, at http://www.westbradford.org/htmls/History/history.html. 
Wilde, F.D., Radtke, D.B., Gibs, J., and Iwatsubo, R.T., eds., 1999, National field manual for the collection of water-quality data: U.S. Geological Survey Techniques of Water-

Resources Investigations, book 9, chap. A4, 103 p.

Wolman, M.G., 1954, A method for sampling coarse river-bed material: Transactions of the American Geophysical Union, v. 35, p. 951-956. 


\section{Glossary}

A

Aggradation The accumulation of sediment within a stream channel at a rate that exceeds the capacity of the stream to transport that material downstream.

\section{B}

Bankfull channel The active stream channel during the bankfull discharge.

Bankfull cross-sectional area The crosssectional area of the bankfull channel measured perpendicular to the streamflow.

Bankfull discharge The most effective streamflow for moving sediment, forming or removing bars, forming or changing bends and meanders, and generally doing work that results in the average morphological characteristics of channels (Dunne and Leopold, 1978)

Bankfull mean depth The average or mean depth of the bankfull channel measured perpendicular to the streamflow.

Bankfull slope The change in elevation of the bankfull channel (rise) divided by the distance along the line of maximum depth of the bankfull channel (run).

Bankfull width The top width of the channel, measured perpendicular to streamflow, at bankfull stage.

Benthic macroinvertebrates The relatively larger aquatic organisms that live on the bottom of a stream that do not have spines. The relative populations of these organisms are indicative of water quality and overall stream health.

\section{C}

Competent (Competence) The ability of a stream to transport the largest particles supplied to it from upstream. Competence refers to particle size and not the amount of particles that can be transported.

Contracted Referring to any restriction within a stream channel that causes streamflow to converge and flow through a smaller, generally more narrow passage or opening.
E

Entrenched A stream channel that has abandoned its floodplain. Rosgen (1996) defines an entrenched stream channel in terms of a ratio between the width of the flood-prone area at an elevation twice the maximum bankfull depth divided by the bankfull width at bankfull stage; if this ratio is less than or equal to 1.4 , the channel is considered entrenched.

EPT taxa richness The total number of taxa within the orders Ephemeroptera (mayflies), Plecoptera (stoneflies), and Trichoptera (caddisflies).

Evulsion Localized stream reach exhibiting relatively severe streambank erosion that can be caused all, or in part, by both human activity or natural causes.

\section{G}

Graded A stream condition where a balance is present between sediment supply and the capacity to transport that sediment. Also known as dynamic equilibrium.

Gully (Gullies) A small, narrow, and relatively deep stream channel found during the initial stages of stream-channel development. A gully is generally classified under the Rosgen (1996) stream-classification system as a G-class channel with an entrenchment ratio of less than 1.4, a width to depth ratio of less than 12 , a slope between 0.02 to $0.039 \mathrm{ft} / \mathrm{ft}$, and a sinuosity greater than 1.2 .

\section{H}

HBI Index value based on the sensitivity of organisms to organic pollution, water quality, and habitat conditions. Values range from 0 (least tolerant) to 10 (most tolerant) with respect to organic pollution, water quality, and habitat conditions.

Head cut The upstream-trending erosion of a waterfall or steep riffle in a stream channel; headcuts are often associated with disturbed stream reaches that are eroding the streambed. 
I

Igneous rocks The word igneous is based on the Latin word for fire; thus, igneous rocks are initially very hot and molten. The two basic kinds of igneous rock are intrusive and extrusive. Intrusive igneous rocks never reach the surface in a liquid state and cool, slowly, deep underground; extrusive igneous rocks reach the surface as a liquid (lava) and cool very quickly. Intrusive igneous rocks generally have much larger crystals (visible to the naked eye) than do extrusive igneous rocks because of the slow rate at which they cool.

Imbricated Overlapping bed materials that are positioned on the streambed in a manner similar to shingles on a roof; flat materials, such as the "platy" rocks derived from schist, often orient themselves in this fashion naturally because this affords the greatest resistance to movement.

\section{M}

Massif A block of crustal material (rock) that is bounded by faults, or substantial folds, and has been displaced without substantial internal deformation.

Metamorphic rocks Metamorphic means "later change" and locally describes the change observed in the form of a rock due to the intense heat and pressure resulting from deep burial and (or) the crustal shifts often associated with mountain-building forces. All rocks can be metamorphosed and changed into completely new rocks by either physical changes, chemical changes, or a combination of both.

\section{$\mathbf{P}$}

Pattern The shape of a stream channel as observed from above. For example, the sinuosity of the stream channel (how much the stream curves back and forth within its valley) describes a component of the pattern of the stream channel.

Profile The stream channel as observed from the side. For example, the slope of the stream channel (how much elevation is lost over a given reach) is a component of the profile of the stream channel.

\section{$\mathbf{R}$}

Rill Small (less than $30 \mathrm{~cm}$ deep) channels. As soil becomes saturated, water initially begins to flow overland as a sheet (sheet flow). The flow from this sheet eventually begins to concentrate in small streams, or rivulets, which create rills through erosion. These rills, if increased in size, would appear very similar to a G-class channel or gully.

Riparian Relating to the banks of a river or stream; for example, riparian vegetation.

\section{S}

Sedimentary rocks Based on the Latin word for settle, sedimentary rocks are formed as particulate matter, known as sediment, settles to the bottom of a water body or accumulates at the base of a hillside. These sediments may eventually solidify into solid sedimentary rocks by various natural cementing processes that often include the precipitation of other minerals.

Shear stress A stress, or force, acting in the direction of flow on the streambed and streambanks.

Substrate A base material; such as the base on which an organism lives, the base on which a plant takes root, or the base on which overlying materials rest.

T

Terrane A geographic area in which a particular kind of rock is dominant. 


\section{Appendixes}

\section{Appendix 1. Fluvial geomorphic assessment data tables}

Table 1-1. Data collected and (or) calculated during fluvial geomorphic assessment of Broad Run, Chester County, Pennsylvania.

Table 1-2. Study site locations for fluvial geomorphic study sites, Broad Run, Chester County, Pennsylvania. 
$\left[\mathrm{ft}^{3} / \mathrm{s}\right.$, cubic feet per second; D50, particle size larger than 50-percent of the cumulative streambed sample; D84, particle size larger than 84-percent of the cumulative streambed sample; D50^, particle size larger than 50-percent of the particles within the cumulative core sample; Di, largest particle in the cumulative core sample; mm, millimeter; ft, feet; $\mathrm{ft}^{2}, \mathrm{square}$ feet; $\mathrm{ft} / \mathrm{ft}$, feet per foot; $\mathrm{ft}^{3} / \mathrm{s}$, cubic feet per second; $\mathrm{lb} / \mathrm{ft}^{2}$, pounds per square foot; >, greater than]

\begin{tabular}{|c|c|c|c|c|c|c|c|c|c|c|c|}
\hline $\begin{array}{l}\text { Cross-section } \\
\text { station and study } \\
\text { reach }\end{array}$ & $\begin{array}{l}\text { Stream } \\
\text { class }^{1}\end{array}$ & $\begin{array}{l}\text { Valley } \\
\text { type }^{1}\end{array}$ & $\begin{array}{l}\text { Bankfull } \\
\text { cross- } \\
\text { sectional } \\
\text { area } \\
\left(\mathrm{ft}^{2}\right)\end{array}$ & $\begin{array}{c}\text { Bankfull } \\
\text { width } \\
\text { (ft) }\end{array}$ & $\begin{array}{c}\text { Bankfull } \\
\text { mean depth } \\
\text { (ft) }\end{array}$ & $\begin{array}{l}\text { Bankfull } \\
\text { maximum } \\
\text { depth } \\
\text { (ft) }\end{array}$ & $\begin{array}{c}\text { Bankfull } \\
\text { water- } \\
\text { surface } \\
\text { slope } \\
\text { (ft/ft) }\end{array}$ & $\begin{array}{c}\text { Manning's } \\
n \\
\text { coefficient } \\
\text { (dimen- } \\
\text { sionless) }\end{array}$ & $\begin{array}{l}\text { Estimated } \\
\text { bankfull } \\
\text { discharge } \\
\left(\mathrm{ft}^{3} / \mathbf{s}\right)\end{array}$ & $\begin{array}{l}\text { Hydraulic } \\
\text { radius } \\
\text { (ft) }\end{array}$ & $\begin{array}{l}\text { Stream } \\
\text { reach } \\
\text { sinuosity }\end{array}$ \\
\hline XS 303 UPPER & $\mathrm{C} 4$ & II & 25.7 & 23.6 & 1.1 & 1.6 & 0.011 & 0.048 & 85 & 1.04 & 1.1 \\
\hline XS 691 UPPER & $\mathrm{C} 4$ & II & 25.8 & 21.6 & 1.2 & 2.0 & .006 & .041 & 81 & 1.11 & 1.1 \\
\hline XS 115 MIDDLE & $\mathrm{C} 4$ & II & 34.5 & 25.0 & 1.4 & 2.0 & .006 & .042 & 115 & 1.30 & 1.3 \\
\hline XS 569 MIDDLE & $\mathrm{C} 4$ & II & 32.9 & 23.5 & 1.4 & 2.6 & .005 & .037 & 112 & 1.32 & 1.3 \\
\hline XS 311 LOWER $^{3}$ & $\mathrm{E} 4$ & VIII & 34.0 & 15.9 & 2.1 & 2.9 & .004 & .127 & 45 & 1.91 & 1.2 \\
\hline XS 616 LOWER & $\mathrm{C} 4$ & VIII & 37.3 & 24.5 & 1.5 & 2.6 & .007 & .115 & 47 & 1.43 & 1.2 \\
\hline $\begin{array}{c}\text { Cross-section } \\
\text { station and study } \\
\text { reach }\end{array}$ & $\begin{array}{l}\text { Entrench- } \\
\text { ment } \\
\text { ratio }\end{array}$ & $\begin{array}{c}\text { Average } \\
\text { D50 } \\
(\mathrm{mm})\end{array}$ & $\begin{array}{c}\text { Average } \\
\text { D84 } \\
(\mathrm{mm})\end{array}$ & $\begin{array}{l}\text { D50^ } \\
(\mathrm{mm})\end{array}$ & $\begin{array}{c}\mathrm{Di} \\
(\mathrm{mm})\end{array}$ & $\begin{array}{c}\text { Estimated } \\
\text { movable } \\
\text { particle } \\
\text { size range } \\
\text { at bankfull } \\
(\mathrm{mm})^{4}\end{array}$ & $\begin{array}{l}\text { Estimated } \\
\text { depth } \\
\text { required to } \\
\text { move } \mathrm{Di} \\
\text { (ft) }\end{array}$ & $\begin{array}{l}\text { Estimated } \\
\text { slope } \\
\text { required to } \\
\text { move Di } \\
\text { (ft/ft) }\end{array}$ & $\begin{array}{c}\text { Maximum } \\
\text { bankfull } \\
\text { shear stress } \\
\left(\mathrm{Ib} / \mathrm{ft}^{2}\right)\end{array}$ & $\begin{array}{l}\text { Dimensionless } \\
\text { critical } \\
\text { shear } \\
\text { stress }\end{array}$ & \\
\hline XS 303 UPPER & $>2.2$ & 41.9 & 132 & 58 & 144 & $60-139$ & 0.90 & 0.009 & 0.70 & 0.013 & \\
\hline XS 691 UPPER & $>2.2$ & 21.7 & 58.8 & 40 & 170 & $39-90$ & 1.9 & .011 & .46 & .014 & \\
\hline XS 115 MIDDLE & $>2.2$ & 39.2 & 110 & 48 & 135 & $42-98$ & 1.5 & .007 & .50 & .013 & \\
\hline XS 569 MIDDLE & $>2.2$ & 17.3 & 71.9 & 74 & 110 & $34-79$ & 2.0 & .007 & .40 & .017 & \\
\hline XS 311 LOWER $^{5}$ & $>2.2$ & 7.6 & 17.9 & 5.0 & 30.0 & $44-104$ & .90 & .002 & .53 & .025 & \\
\hline XS 616 LOWER & $>2.2$ & 21.3 & 80.6 & 43 & 123 & $55-128$ & 1.7 & .008 & .65 & .018 & \\
\hline
\end{tabular}

${ }^{1}$ Rosgen, 1996.

${ }^{2}$ Sinuosity measured over entire reach which includes both cross sections.

${ }^{3}$ Estimated bankfull discharge reflects severe resistance to flow resulting from dense riparian vegetation.

${ }^{4}$ Range based on use of Shields parameters of 0.035 and 0.015 .

${ }^{5}$ Estimated bankfull discharge reflects severe resistance to flow resulting from dense riparian vegetation. 
Table 1-2. Study-site locations for fluvial geomorphic study sites, Broad Run, Chester County, Pennsylvania.

[mi ${ }^{2}$, square miles; ${ }^{\circ}$, degrees; ', minutes; ", seconds; USGS, U.S. Geological Survey; ID, idenification]

\begin{tabular}{|c|c|c|c|c|c|c|c|}
\hline Site name & $\begin{array}{c}\text { Drainage } \\
\text { area } \\
\left(\mathrm{mi}^{2}\right)\end{array}$ & $\begin{array}{c}\text { Longitude/ } \\
\text { latitude at } \\
\text { upstream end } \\
\text { of longitudinal } \\
\text { profile }\end{array}$ & $\begin{array}{l}\text { Longitude/ } \\
\text { latitude at } \\
\text { downstream } \\
\text { end of } \\
\text { longitudinal } \\
\text { profile }\end{array}$ & $\begin{array}{l}\text { Longitude/ } \\
\text { latitude at left } \\
\text { end of } \\
\text { upstream } \\
\text { cross section }\end{array}$ & $\begin{array}{l}\text { Longitude/ } \\
\text { latitude at right } \\
\text { end of } \\
\text { upstream } \\
\text { cross section }\end{array}$ & $\begin{array}{l}\text { Longitude/ } \\
\text { latitude at left } \\
\text { end of } \\
\text { downstream } \\
\text { cross section }\end{array}$ & $\begin{array}{c}\text { Longitude/ } \\
\text { latitude at right } \\
\text { end of } \\
\text { downstream } \\
\text { cross section }\end{array}$ \\
\hline Upper study reach & 1.54 & $\begin{array}{l}75^{\circ} 44^{\prime} 29.56^{\prime \prime} \\
39^{\circ} 57^{\prime} 47.63 "\end{array}$ & $\begin{array}{l}75^{\circ} 44^{\prime} 22.65^{\prime \prime} \\
39^{\circ} 57^{\prime} 41.48^{\prime \prime}\end{array}$ & $\begin{array}{l}75^{\circ} 44^{\prime} 27.28^{\prime \prime} \\
39^{\circ} 57^{\prime} 45.48^{\prime \prime}\end{array}$ & $\begin{array}{l}75^{\circ} 44^{\prime} 28.13^{\prime \prime} \\
39^{\circ} 57^{\prime} 44.81^{\prime \prime}\end{array}$ & $\begin{array}{l}75^{\circ} 44^{\prime} 23.33^{\prime \prime} \\
39^{\circ} 57^{\prime} 43.03^{\prime \prime}\end{array}$ & $\begin{array}{l}75^{\circ} 44^{\prime} 24.53 " \\
39^{\circ} 57^{\prime} 42.36 "\end{array}$ \\
\hline Middle study reach & 4.88 & $\begin{array}{l}75^{\circ} 42^{\prime} 19.68^{\prime \prime} \\
39^{\circ} 56^{\prime} 57.56^{\prime \prime}\end{array}$ & $\begin{array}{l}75^{\circ} 42^{\prime} 13.00 " \\
39^{\circ} 56 ' 52.97 "\end{array}$ & $\begin{array}{l}75^{\circ} 42^{\prime} 19.00^{\prime \prime} \\
39^{\circ} 56^{\prime} 57.50 "\end{array}$ & $\begin{array}{l}75^{\circ} 42^{\prime} 19.45^{\prime \prime} \\
39^{\circ} 56,56.31^{\prime \prime}\end{array}$ & $\begin{array}{l}75^{\circ} 42^{\prime} 14.16^{\prime \prime} \\
39^{\circ} 56^{\prime} 55.00^{\prime \prime}\end{array}$ & $\begin{array}{l}75^{\circ} 42^{\prime} 16.14 ” \\
39^{\circ} 56^{\prime} 54.57^{\prime \prime}\end{array}$ \\
\hline $\begin{array}{l}\text { Lower study reach } \\
\text { (USGS station ID } \\
\text { 01480638, Broad } \\
\text { Run at North- } \\
\text { brook) }\end{array}$ & 6.39 & $\begin{array}{l}75^{\circ} 41^{\prime} 13.84 " \\
39^{\circ} 55^{\prime} 49.03 "\end{array}$ & $\begin{array}{l}75^{\circ} 41^{\prime} 05.88^{\prime \prime} \\
39^{\circ} 55^{\prime} 48.94^{\prime \prime}\end{array}$ & $\begin{array}{l}75^{\circ} 41^{\prime} 11.03 ” \\
39^{\circ} 55^{\prime} 49.51^{\prime \prime}\end{array}$ & $\begin{array}{l}75^{\circ} 41^{\prime} 10.76^{\prime \prime} \\
39^{\circ} 55^{\prime} 48.31^{\prime \prime}\end{array}$ & $\begin{array}{l}75^{\circ} 41^{\prime} 07.51^{\prime \prime} \\
39^{\circ} 55^{\prime} 49.37^{\prime \prime}\end{array}$ & $\begin{array}{l}75^{\circ} 41^{\prime} 06.75^{\prime \prime} \\
39^{\circ} 55^{\prime} 48.20^{\prime \prime}\end{array}$ \\
\hline
\end{tabular}


50 Water Budget and Stream Assessment for the Broad Run Watershed, Chester County, Pennsylvania

\section{Appendix 2. Stream-quality assessment data tables}

Table 2-1. Biological data; benthic macroinvertebrates, Broad Run, Chester County, Pennsylvania.

Table 2-2. Discharge, field-measured water-quality characteristics and results from chemical sampling at biological sampling sites, Broad Run, Chester County, Pennsylvania, 1999-2002. 
Table 2-1. Biological data; benthic macroinvertebrates, Broad Run, Chester County, Pennsylvania.

[Samples were collected using a Hess sampler with a mesh size of 500 millimeters. Three samples covered a total area of 2.4 square meters. --, no observations of the organism in the sampler]

\begin{tabular}{|c|c|c|c|c|c|c|c|c|}
\hline \multirow{2}{*}{$\begin{array}{c}\text { Station number } \\
\text { Date }\end{array}$} & \multicolumn{3}{|c|}{01480636} & \multicolumn{2}{|c|}{0148063750} & \multicolumn{3}{|c|}{01480638} \\
\hline & $\begin{array}{c}\text { Nov. } 9 \\
1999\end{array}$ & $\begin{array}{c}\text { Oct. } 29 \\
2001\end{array}$ & $\begin{array}{c}\text { Dec. } 17 \\
2002\end{array}$ & $\begin{array}{c}\text { Oct. } 29 \\
2001\end{array}$ & $\begin{array}{c}\text { Dec. } 17 \\
2002\end{array}$ & $\begin{array}{c}\text { Nov. } 9 \\
1999\end{array}$ & $\begin{array}{c}\text { Oct. } 29 \\
2001\end{array}$ & $\begin{array}{c}\text { Nov. 26 } \\
2002\end{array}$ \\
\hline Benthic macroinvertebrate & Count & Count & Count & Count & Count & Count & Count & Count \\
\hline
\end{tabular}

Platyhelminthes

Turbellaria (FLATWORMS)

Tricladida

Planariidae

Nematoda (NEMATODES)

\section{2}

13

Nemertea (PROBOSCIS WORMS)

Enopla

Hoplonemertea

Tetrastemmatidae

Prostoma

$--1$

14

31

2

26

61

194

2

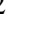

(n)

$\begin{array}{lll}5 & 46 & 52\end{array}$

Mollusca

Bivalvia (CLAMS)

Veneroida

Sphaeriidae

Annelida

Oligochaeta (AQUATIC EARTHWORMS)

$\begin{array}{lll}6 & 9 & 30\end{array}$

Tubificida

$$
\text { Naididae }
$$

Arthropoda

Acariformes

Hydrachnidia (WATER MITES)

29

30

22

$--$

9

0

13

10

3

Crustacea

Cyclopoida

$$
\text { Cyclopidae }
$$

Amphipoda (SCUDS)

Crangonyctidae

$$
\text { Stygonectes }
$$

Isopoda (AQUATIC SOWBUGS)

Asellidae

\section{Caecidotea}

Podocopa

Insecta

Ephemeroptera (MAYFLIES)

Baetidae

Acentrella

Baetis
77

77

0

--

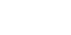


52 Water Budget and Stream Assessment for the Broad Run Watershed, Chester County, Pennsylvania

Table 2-1. Biological data; benthic macroinvertebrates, Broad Run, Chester County, Pennsylvania.

[Samples were collected using a Hess sampler with a mesh size of 500 millimeters. Three samples covered a total area of 2.4 square meters. --, no observations of the organism in the sampler]

\begin{tabular}{|c|c|c|c|c|c|c|c|c|}
\hline \multirow{2}{*}{$\begin{array}{c}\text { Station number } \\
\text { Date }\end{array}$} & \multicolumn{3}{|c|}{01480636} & \multicolumn{2}{|c|}{0148063750} & \multicolumn{3}{|c|}{01480638} \\
\hline & $\begin{array}{l}\text { Nov. } 9 \\
1999\end{array}$ & $\begin{array}{c}\text { Oct. } 29 \\
2001\end{array}$ & $\begin{array}{c}\text { Dec. } 17 \\
2002\end{array}$ & $\begin{array}{l}\text { Oct. } 29 \\
2001\end{array}$ & $\begin{array}{c}\text { Dec. } 17 \\
2002\end{array}$ & $\begin{array}{l}\text { Nov. } 9 \\
1999\end{array}$ & $\begin{array}{c}\text { Oct. } 29 \\
2001\end{array}$ & $\begin{array}{l}\text { Nov. 26, } \\
2002\end{array}$ \\
\hline Benthic macroinvertebrate & Count & Count & Count & Count & Count & Count & Count & Count \\
\hline \multicolumn{9}{|l|}{ Caenidae } \\
\hline Caenis & -- & -- & -- & -- & -- & -- & -- & 2 \\
\hline \multicolumn{9}{|l|}{ Ephemerellidae } \\
\hline Dannella & -- & -- & -- & -- & -- & -- & 1 & -- \\
\hline Eurylophella & 6 & 41 & 9 & 13 & 49 & 5 & -- & 9 \\
\hline Serratella & 45 & 665 & 88 & 137 & 640 & 40 & 16 & 154 \\
\hline \multicolumn{9}{|l|}{ Heptageniidae } \\
\hline Epeorus & 1 & -- & -- & -- & 2 & -- & 1 & -- \\
\hline Stenonema & 11 & 168 & 23 & 85 & 126 & 6 & 3 & 17 \\
\hline \multicolumn{9}{|l|}{ Isonychiidae } \\
\hline Isonychia & -- & -- & -- & 16 & 24 & -- & -- & 6 \\
\hline \multicolumn{9}{|l|}{ Leptohyphidae } \\
\hline Tricorythodes & -- & -- & -- & 5 & 3 & -- & -- & -- \\
\hline \multicolumn{9}{|l|}{ Leptophlebiidae } \\
\hline Paraleptophlebia & 7 & 9 & -- & -- & -- & -- & -- & -- \\
\hline \multicolumn{9}{|c|}{$\begin{array}{l}\text { Odonata (DRAGONFLIES AND DAM- } \\
\text { SELFLIES) }\end{array}$} \\
\hline \multicolumn{9}{|l|}{ Coenagrionidae } \\
\hline Argia & -- & -- & -- & -- & 1 & -- & -- & -- \\
\hline Gomphidae & -- & -- & 9 & -- & -- & -- & -- & -- \\
\hline Stylogomphus & -- & 11 & -- & -- & -- & -- & 2 & -- \\
\hline
\end{tabular}

Plecoptera (STONEFLIES)

Capniidae

Allocapnia

Chloroperlidae

Leuctridae

Paraleuctra

Nemouridae

Paranemoura

Perlidae

Acroneuria

Agnetina

Paragnetina

Taeniopterygidae

Strophopteryx

Taeniopteryx
$11 \quad--\quad 60$

$--\quad 20$

$--$

$--$ 
Table 2-1. Biological data; benthic macroinvertebrates, Broad Run, Chester County, Pennsylvania.

[Samples were collected using a Hess sampler with a mesh size of 500 millimeters. Three samples covered a total area of 2.4 square meters. --, no observations of the organism in the sampler]

\begin{tabular}{|c|c|c|c|c|c|c|c|c|}
\hline \multirow{2}{*}{$\begin{array}{c}\text { Station number } \\
\text { Date }\end{array}$} & \multicolumn{3}{|c|}{01480636} & \multicolumn{2}{|c|}{0148063750} & \multicolumn{3}{|c|}{01480638} \\
\hline & $\begin{array}{c}\text { Nov. } 9 \\
1999\end{array}$ & $\begin{array}{c}\text { Oct. } 29 \\
2001\end{array}$ & $\begin{array}{c}\text { Dec. } 17 \\
2002\end{array}$ & $\begin{array}{c}\text { Oct. } 29 \\
2001\end{array}$ & $\begin{array}{c}\text { Dec. } 17 \\
2002\end{array}$ & $\begin{array}{c}\text { Nov. } 9 \\
1999\end{array}$ & $\begin{array}{c}\text { Oct. } 29 \\
2001\end{array}$ & $\begin{array}{c}\text { Nov. 26, } \\
2002\end{array}$ \\
\hline Benthic macroinvertebrate & Count & Count & Count & Count & Count & Count & Count & Count \\
\hline
\end{tabular}

Hemiptera (TRUE BUGS)

Veliidae

Rhagovelia

Megaloptera

Corydalidae (FISHFLIES AND DOB-

SONFLIES)

Corydalus

Nigronia

Sialidae (ALDERFLIES)

Sialis

Trichoptera (CADDISFLIES)

Brachycentridae

$$
\text { Micrasema }
$$

Glossosomatidae

Glossosoma

$4 \quad 42$

1

31

21

2108

66

Goeridae

Goera

Hydropsychidae

Cheumatopsyche

Hydropsyche

8

69

17

35

11

\begin{tabular}{|c|c|}
\hline & 01480638 \\
\hline $\begin{array}{l}\text { Nov. } 9 \\
1999\end{array}$ & $\begin{array}{c}\text { Oct. } 29 \\
2001\end{array}$ \\
\hline Count & Count \\
\hline -- & -- \\
\hline -- & -- \\
\hline 2 & 2 \\
\hline 1 & 2 \\
\hline 2 & 108 \\
\hline 1 & 5 \\
\hline-- & -- \\
\hline 23 & 248 \\
\hline 60 & 136 \\
\hline 3 & -- \\
\hline -- & -- \\
\hline-- & 2 \\
\hline-- & -- \\
\hline 42 & 56 \\
\hline-- & 4 \\
\hline 1 & -- \\
\hline 4 & 5 \\
\hline
\end{tabular}

10

Hydroptilidae

Hydroptila

Leucotrichia

Lepidostomatidae

Lepidostoma

Leptoceridae

Oecetis

Philopotamidae

Chimarra

Dolophilodes

Wormaldia

Polycentropodidae

Polycentropus

$27 \quad 631$

$93 \quad 537$

95

192

414

551

807

87

25

10

4

Psychomyiidae

Lype

Psychomyia

$4 \quad 81$

$3 \quad 92$

-- $\quad$--

136

2

$-$

$73 \quad 36$

$--\quad 5$

4 
54 Water Budget and Stream Assessment for the Broad Run Watershed, Chester County, Pennsylvania

Table 2-1. Biological data; benthic macroinvertebrates, Broad Run, Chester County, Pennsylvania.

[Samples were collected using a Hess sampler with a mesh size of 500 millimeters. Three samples covered a total area of 2.4 square meters. --, no observations of the organism in the sampler]

\begin{tabular}{|c|c|c|c|c|c|c|c|c|}
\hline \multirow{2}{*}{$\begin{array}{c}\text { Station number } \\
\text { Date }\end{array}$} & \multicolumn{3}{|c|}{01480636} & \multicolumn{2}{|c|}{0148063750} & \multicolumn{3}{|c|}{01480638} \\
\hline & $\begin{array}{c}\text { Nov. } 9 \\
1999\end{array}$ & $\begin{array}{c}\text { Oct. 29 } \\
2001\end{array}$ & $\begin{array}{c}\text { Dec. } 17 \\
2002\end{array}$ & $\begin{array}{c}\text { Oct. } 29 \\
2001\end{array}$ & $\begin{array}{c}\text { Dec. } 17 \\
2002\end{array}$ & $\begin{array}{c}\text { Nov. } 9 \\
1999\end{array}$ & $\begin{array}{c}\text { Oct. } 29 \\
2001\end{array}$ & $\begin{array}{c}\text { Nov. 26, } \\
2002\end{array}$ \\
\hline Benthic macroinvertebrate & Count & Count & Count & Count & Count & Count & Count & Count \\
\hline \multicolumn{9}{|l|}{ Rhyacophilidae } \\
\hline Rhyacophila & -- & 23 & 6 & -- & -- & -- & -- & 3 \\
\hline \multicolumn{9}{|l|}{ Uenoidae } \\
\hline Neophylax & 11 & -- & 10 & -- & -- & -- & -- & 4 \\
\hline \multicolumn{9}{|l|}{ Coleoptera (BEETLES) } \\
\hline \multicolumn{9}{|l|}{ Dryopidae } \\
\hline Helichus & -- & -- & -- & -- & -- & -- & 1 & -- \\
\hline \multicolumn{9}{|l|}{ Elmidae (RIFFLE BEETLES) } \\
\hline Ancyronyx & 4 & -- & -- & -- & -- & 34 & -- & -- \\
\hline Dubiraphia & 1 & 6 & 10 & -- & 1 & -- & 1 & -- \\
\hline Macronychus & -- & 1 & 2 & -- & -- & -- & -- & 3 \\
\hline Optioservus & 93 & 660 & 320 & 477 & 211 & 124 & 222 & 587 \\
\hline Oulimnius & 42 & 133 & 89 & 59 & 40 & 102 & 118 & 292 \\
\hline Promoresia & -- & 3 & -- & 13 & 29 & -- & 62 & 71 \\
\hline Stenelmis & 3 & 30 & 16 & 62 & 34 & 37 & 127 & 95 \\
\hline \multicolumn{9}{|l|}{ Hydrophilidae } \\
\hline Helophorus & -- & 1 & -- & -- & -- & -- & -- & -- \\
\hline \multicolumn{9}{|l|}{ Psephenidae (WATER PENNIES) } \\
\hline Ectopria & -- & -- & -- & -- & 1 & -- & -- & -- \\
\hline Psephenus & 6 & 117 & 10 & 121 & 76 & 9 & 15 & 54 \\
\hline \multicolumn{9}{|l|}{ Ptilodactylidae } \\
\hline Anchytarsus & 3 & -- & 7 & -- & -- & -- & -- & -- \\
\hline \multicolumn{9}{|l|}{ Diptera (TRUE FLIES) } \\
\hline Ceratopogonidae (BITING MIDGES) & 1 & 1 & 1 & -- & 1 & -- & -- & 1 \\
\hline Chironomidae (MIDGES) & 525 & 240 & 521 & 329 & 440 & 45 & 320 & 509 \\
\hline \multicolumn{9}{|l|}{ Empididae (DANCE FLIES) } \\
\hline Hemerodromia & 2 & 1 & 2 & 1 & 2 & -- & 2 & 14 \\
\hline Ephydridae & -- & -- & -- & -- & -- & -- & -- & 2 \\
\hline \multicolumn{9}{|l|}{ Simuliidae (BLACK FLIES) } \\
\hline Prosimulium & -- & -- & 194 & -- & 9 & -- & -- & -- \\
\hline Simulium & 8 & 7 & -- & 5 & 131 & 2 & 1 & 30 \\
\hline Tipulidae (CRANE FLIES) & -- & -- & -- & -- & -- & 1 & -- & -- \\
\hline Antocha & 8 & 39 & 4 & 71 & 65 & 3 & 19 & 66 \\
\hline Dicranota & 6 & 4 & -- & 1 & 1 & -- & -- & -- \\
\hline Tipula & -- & 3 & 8 & -- & -- & -- & 1 & -- \\
\hline Total organisms & 1,098 & 3,970 & 1,966 & 2,647 & 4,238 & 624 & 1,687 & 3,384 \\
\hline Total number of taxa & 43 & 43 & 45 & 39 & 46 & 35 & 41 & 45 \\
\hline
\end{tabular}


Table 2-2. Discharge, field-measured water-quality characteristics, and results from chemical sampling at biological-sampling sites, Broad Run, Chester County, Pennsylvania, 1999-2002.

$\left[\mathrm{ft}^{3} / \mathrm{s}\right.$, cubic feet per second; mg/L, milligrams per liter; $\mu \mathrm{s} / \mathrm{cm}$, microsiemens per centimeter; deg C, degrees Celsius; <, less than; E, estimated value]

\begin{tabular}{|c|c|c|c|c|c|c|c|c|c|}
\hline Date & Time & $\begin{array}{c}\text { Instan- } \\
\text { taneous } \\
\text { discharge, } \\
\mathrm{ft}^{3} / \mathrm{s} \\
(00061)\end{array}$ & $\begin{array}{c}\text { Dissolved } \\
\text { oxygen, } \\
\text { mg/L } \\
(00300)\end{array}$ & $\begin{array}{c}\text { pH } \\
\text { water, } \\
\text { unfiltered, } \\
\text { standard } \\
\text { units } \\
(00400)\end{array}$ & $\begin{array}{c}\text { Specific } \\
\text { conductance, } \\
\text { water, } \\
\text { unfiltered } \\
\mu S / \mathrm{cm} \\
(00095)\end{array}$ & $\begin{array}{c}\text { Temper- } \\
\text { ature } \\
\text { water, } \\
\operatorname{deg} C \\
(00010)\end{array}$ & $\begin{array}{c}\text { Calcium } \\
\text { water, } \\
\text { filtered, } \\
\text { mg/L } \\
\text { (00915) }\end{array}$ & $\begin{array}{c}\text { Magnesium } \\
\text { water, } \\
\text { filtered, } \\
\text { mg/L } \\
\text { (00925) }\end{array}$ & $\begin{array}{c}\text { Potassium } \\
\text { water, } \\
\text { filtered, } \\
\text { mg/L } \\
(00935)\end{array}$ \\
\hline \multicolumn{10}{|c|}{ (01480636) Broad Run at Romansville, PA } \\
\hline $11-09-99$ & 1130 & 1.8 & 12.2 & 7.3 & 180 & 9.0 & 13.3 & 7.24 & 1.09 \\
\hline $10-29-01$ & 1230 & .55 & 10.5 & 7.4 & 193 & 10 & 15.1 & 7.93 & 1.40 \\
\hline $12-17-02$ & 1200 & 5.5 & 11.8 & 6.8 & 188 & 5.4 & 12.5 & 7.11 & 1.31 \\
\hline \multicolumn{10}{|c|}{ (0148063750) Broad Run near Marshallton } \\
\hline $10-29-01$ & 1100 & 1.4 & 12.0 & 7.3 & 229 & 7.0 & 18.7 & 8.45 & 1.79 \\
\hline $11-26-02$ & 1300 & 4.4 & 12.1 & 7.2 & 231 & 8.7 & 18.1 & 8.41 & 1.46 \\
\hline \multicolumn{10}{|c|}{ (01480638) Broad Run at Northbrook } \\
\hline $11-09-99$ & 0930 & 4.6 & 12.2 & 7.4 & 200 & 6.5 & 15.9 & 7.51 & 1.71 \\
\hline $10-29-01$ & 0845 & 1.7 & 10.5 & 7.2 & 213 & 5.5 & 17.2 & 7.82 & 1.96 \\
\hline $11-26-02$ & 0930 & 5.0 & 10.1 & 7.2 & 224 & 6.7 & 17.4 & 8.06 & 1.39 \\
\hline
\end{tabular}

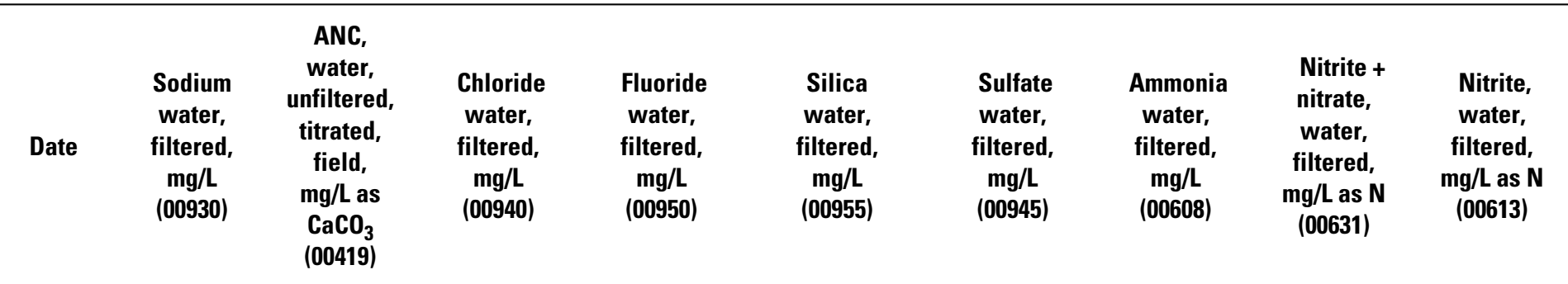

\begin{tabular}{|c|c|c|c|c|c|c|c|c|c|}
\hline \multicolumn{10}{|c|}{ (01480636) Broad Run at Romansville, PA } \\
\hline $11-09-99$ & 8.51 & 30 & 17.9 & $<0.10$ & 8.3 & 13.6 & $<0.02$ & 2.81 & $<0.010$ \\
\hline $10-29-01$ & 8.05 & 34 & 18.9 & $<.10$ & 9.3 & 13.8 & $<.04$ & 2.73 & E.005 \\
\hline $12-17-02$ & 9.95 & 25 & 19.7 & $<.17$ & 7.4 & 15.5 & $<.04$ & 2.75 & $<.008$ \\
\hline \multicolumn{10}{|c|}{ (0148063750) Broad Run near Marshallton } \\
\hline $10-29-01$ & 9.89 & 50 & 22.6 & $<.10$ & 11.8 & 17.2 & $<.04$ & 2.50 & $<.008$ \\
\hline $11-26-02$ & 11.1 & 47 & 22.5 & $<.17$ & 9.5 & 18.1 & $<.04$ & 2.80 & E.005 \\
\hline \multicolumn{10}{|c|}{ (01480638) Broad Run at Northbrook } \\
\hline $11-09-99$ & 9.60 & 34 & 19.2 & $<.10$ & 10.7 & 16.5 & $<.02$ & 2.65 & $<.010$ \\
\hline $10-29-01$ & 9.33 & 42 & 20.5 & $<.10$ & 11.4 & 18.6 & $<.04$ & 2.08 & E.005 \\
\hline $11-26-02$ & 10.6 & 36 & 21.3 & $<.17$ & 9.9 & 17.5 & $<.04$ & 2.61 & E.004 \\
\hline
\end{tabular}




\begin{tabular}{|c|c|c|c|c|c|c|c|}
\hline Date & $\begin{array}{c}\text { Ortho- } \\
\text { phosphate, } \\
\text { water, } \\
\text { filtered, } \\
\text { mg/L as P } \\
\text { (00671) }\end{array}$ & $\begin{array}{c}\text { Aluminum, } \\
\text { water, } \\
\text { filtered, } \\
\mu \mathrm{g} / \mathrm{L} \\
(\mathbf{0 1 1 0 6 )}\end{array}$ & $\begin{array}{c}\text { Arsenic, } \\
\text { water, } \\
\text { filtered, } \\
\mu \mathrm{g} / \mathrm{L} \\
(01000)\end{array}$ & $\begin{array}{c}\text { Boron, } \\
\text { water, } \\
\text { filtered, } \\
\mu \mathrm{g} / \mathrm{L} \\
(01020)\end{array}$ & $\begin{array}{c}\text { Cadmium } \\
\text { water, } \\
\text { filtered, } \\
\mu \mathrm{g} / \mathrm{L} \\
(01025)\end{array}$ & $\begin{array}{l}\text { Chromium } \\
\text { water, } \\
\text { filtered, } \\
\mu \mathrm{g} / \mathrm{L} \\
\text { (01030) }\end{array}$ & $\begin{array}{c}\text { Copper } \\
\text { water, } \\
\text { filtered, } \\
\mu \mathrm{g} / \mathrm{L} \\
(01040)\end{array}$ \\
\hline \multicolumn{8}{|c|}{ (01480636) Broad Run at Romansville, PA } \\
\hline 11-09-99 & $<0.01$ & $<10$ & $<2$ & 16 & $<0.1$ & $<0.8$ & $<1.3$ \\
\hline $10-29-01$ & $<.02$ & -- & -- & 30 & -- & -- & -- \\
\hline $12-17-02$ & $<.02$ & -- & -- & 31 & -- & -- & -- \\
\hline \multicolumn{8}{|c|}{ (0148063750) Broad Run near Marshallton } \\
\hline $10-29-01$ & $<.02$ & -- & -- & 26 & -- & -- & -- \\
\hline $11-26-02$ & $<.02$ & -- & -- & 36 & -- & -- & -- \\
\hline \multicolumn{8}{|c|}{ (01480638) Broad Run at Northbrook } \\
\hline $11-09-99$ & $<.01$ & $<20$ & $<2$ & E13 & $<.1$ & 1.0 & $<1.3$ \\
\hline $10-29-01$ & $<.02$ & -- & -- & 27 & -- & -- & -- \\
\hline $11-26-02$ & $<.02$ & $<20$ & $<2$ & 38 & $<.2$ & $<.8$ & $<1.2$ \\
\hline Date & $\begin{array}{c}\text { Iron, } \\
\text { water, } \\
\text { filtered, } \\
\mu \mathrm{g} / \mathrm{L} \\
(01046)\end{array}$ & $\begin{array}{c}\text { Lead, } \\
\text { water, } \\
\text { filtered, } \\
\mu \mathrm{g} / \mathrm{L} \\
\text { (01049) }\end{array}$ & $\begin{array}{c}\text { Manganese, } \\
\text { water, } \\
\text { filtered, } \\
\mu \mathrm{g} / \mathrm{L} \\
(01056)\end{array}$ & $\begin{array}{c}\text { Mercury, } \\
\text { water, } \\
\text { filtered, } \\
\mu \mathrm{g} / \mathrm{L} \\
(71890)\end{array}$ & $\begin{array}{c}\text { Molybdenum, } \\
\text { water, } \\
\text { filtered, } \\
\mu \mathrm{g} / \mathrm{L} \\
(01060)\end{array}$ & $\begin{array}{c}\text { Nickel, } \\
\text { water, } \\
\text { filtered, } \\
\mu \mathrm{g} / \mathrm{L} \\
\text { (01065) }\end{array}$ & $\begin{array}{c}\text { Zinc, } \\
\text { water, } \\
\text { filtered, } \\
\mu \mathrm{g} / \mathrm{L} \\
(01090)\end{array}$ \\
\hline \multicolumn{8}{|c|}{ (01480636) Broad Run at Romansville, PA } \\
\hline $11-09-99$ & 12 & $<1$ & 12.6 & $<0.2$ & $<1.0$ & $<1.4$ & $<20$ \\
\hline $10-29-01$ & 15 & -- & -- & -- & -- & -- & -- \\
\hline $12-17-02$ & 15 & -- & -- & -- & -- & -- & -- \\
\hline \multicolumn{8}{|c|}{ (0148063750) Broad Run near Marshallton } \\
\hline $10-29-01$ & 23 & -- & -- & -- & -- & -- & -- \\
\hline $11-26-02$ & 43 & -- & -- & -- & -- & -- & -- \\
\hline \multicolumn{8}{|c|}{ (01480638) Broad Run at Northbrook } \\
\hline $11-09-99$ & 24 & $<1$ & 14.1 & $<.20$ & $<1.0$ & $<1.4$ & $<20$ \\
\hline $10-29-01$ & 27 & -- & -- & -- & -- & -- & -- \\
\hline $11-26-02$ & 32 & $<1$ & 26.7 & $<.02$ & $<1.8$ & $<2.0$ & $<24$ \\
\hline
\end{tabular}




\section{Appendix 3 - Annual water budget data tables}

Table 3-1. Record of observation wells analyzed for use in computation of annual water budget for the Broad Run watershed, Chester County, Pennsylvania.

Table 3-2. Monthly water-level measurements from observation-well network, 2003 to 2004, Chester County, Pennsylvania. 


\section{Water Budget and Stream Assessment for the Broad Run Watershed, Chester County, Pennsylvania}

Table 3-1. Record of observation wells analyzed for use in computation of annual-water budget for the Broad Run watershed, Chester County, Pennsylvania.

Use of site: O, observation well; W, withdrawal.

Use of water: $\mathrm{C}$, commercial; $\mathrm{H}$, domestic; P, public supply; U, unused.

Topographic setting: H, hilltop; S, hillside; V, valley flat; W, upland draw.

Hydrogeologic unit: 300PRCK, Peters Creek Schist; 300WSCKO, Wissahickon Schist; 300WSCKA, Octoraro Phyllite.

[', degrees; ', minutes; ", seconds; Twp, Township]

\begin{tabular}{|c|c|c|c|c|c|c|c|c|}
\hline \multirow{2}{*}{$\begin{array}{c}\text { U.S. } \\
\text { Geological } \\
\text { Survey well } \\
\text { number }\end{array}$} & \multicolumn{2}{|c|}{ Location } & \multirow{2}{*}{ Township } & \multirow[b]{2}{*}{ Owner } & \multicolumn{2}{|c|}{ Primary } & \multirow{2}{*}{$\begin{array}{c}\text { Topo- } \\
\text { graphic } \\
\text { setting }\end{array}$} & \multirow{2}{*}{$\begin{array}{l}\text { Hydro- } \\
\text { geologic } \\
\text { unit }\end{array}$} \\
\hline & Latitude & Longitude & & & $\begin{array}{l}\text { Use of } \\
\text { site }\end{array}$ & $\begin{array}{l}\text { Use of } \\
\text { water }\end{array}$ & & \\
\hline CH-1158 & $39^{\circ} 58^{\prime} 28.36^{\prime \prime}$ & $75^{\circ} 44^{\prime} 44.77^{\prime \prime}$ & W. Bradford & March & $\mathrm{W}$ & $\mathrm{H}$ & $S$ & 300WSCKA \\
\hline $\mathrm{CH}-5071^{1}$ & $39^{\circ} 55^{\prime} 58.45^{\prime \prime}$ & $75^{\circ} 41^{\prime} 33.90^{\prime \prime}$ & W. Bradford & Latta & W & $\mathrm{H}$ & $\mathrm{V}$ & 300WSCKO \\
\hline CH-6519 & $39^{\circ} 56^{\prime} 34.40^{\prime \prime}$ & $75^{\circ} 44^{\prime} 25.92^{\prime \prime}$ & Newlin & Newlin Twp. & $\mathrm{O}$ & $\mathrm{U}$ & S & 300PRCK \\
\hline CH-6664 & $39^{\circ} 56^{\prime} 42.75^{\prime \prime}$ & $75^{\circ} 42^{\prime} 01.81^{\prime \prime}$ & W. Bradford & Temenos & $\mathrm{W}$ & $\mathrm{H}$ & $S$ & 300WSCKO \\
\hline CH-6665 & $39^{\circ} 56^{\prime} 46.00^{\prime \prime}$ & $75^{\circ} 41^{\prime} 55.78^{\prime \prime}$ & W. Bradford & Temenos & $\mathrm{W}$ & $\mathrm{U}$ & W & 300WSCKO \\
\hline CH- $6666^{1}$ & $39^{\circ} 56^{\prime} 42.75^{\prime \prime}$ & $75^{\circ} 41^{\prime} 54.50^{\prime \prime}$ & W. Bradford & Temenos & $\mathrm{W}$ & $\mathrm{P}$ & $\mathrm{H}$ & 300WSCKO \\
\hline $\mathrm{CH}-6667^{1}$ & $39^{\circ} 56^{\prime} 34.24 \prime$ & $75^{\circ} 42^{\prime} 40.95^{\prime \prime}$ & W. Bradford & W. Bradford Twp. & $\mathrm{O}$ & $\mathrm{U}$ & S & 300WSCKO \\
\hline $\mathrm{CH}-6668^{1}$ & $39^{\circ} 56^{\prime} 37.25^{\prime \prime}$ & $75^{\circ} 42^{\prime} 40.61^{\prime \prime}$ & W. Bradford & W. Bradford Twp & $\mathrm{O}$ & $\mathrm{U}$ & S & 300WSCKO \\
\hline CH-6669 & $39^{\circ} 57^{\prime} 13.96 ”$ & $75^{\circ} 43^{\prime} 38.86^{\prime \prime}$ & W. Bradford & McElhaney & $\mathrm{W}$ & $\mathrm{H}$ & S & 300PRCK \\
\hline CH-6670 & $39^{\circ} 57^{\prime} 15.33^{\prime \prime}$ & $75^{\circ} 43^{\prime} 53.58^{\prime \prime}$ & W. Bradford & Powell & W & $\mathrm{U}$ & $S$ & 300PRCK \\
\hline $\mathrm{CH}-6671^{1}$ & $39^{\circ} 57^{\prime} 11.95^{\prime \prime}$ & $75^{\circ} 43^{\prime} 52.57^{\prime \prime}$ & W. Bradford & Kalbach & $\mathrm{W}$ & $\mathrm{H}$ & S & 300PRCK \\
\hline $\mathrm{CH}-6672^{1}$ & $39^{\circ} 58^{\prime} 14.73^{\prime \prime}$ & $75^{\circ} 43^{\prime} 09.77^{\prime \prime}$ & W. Bradford & Hollway & $\mathrm{W}$ & $\mathrm{H}$ & $\mathrm{H}$ & 300WSCKA \\
\hline CH-6673 & $39^{\circ} 57^{\prime} 34.95^{\prime \prime}$ & $75^{\circ} 42^{\prime} 52.86^{\prime \prime}$ & W. Bradford & Mathews & W & $\mathrm{H}$ & S & 300PRCK \\
\hline CH-6674 & $39^{\circ} 57^{\prime} 39.48^{\prime \prime}$ & $75^{\circ} 41^{\prime} 52.43^{\prime \prime}$ & W. Bradford & Highland Orchard & W & $\mathrm{C}$ & $\mathrm{H}$ & 300WSCKO \\
\hline
\end{tabular}

${ }^{1}$ Wells selected for use in computation of the annual water budget. 
Table 3-2. Monthly water-level measurements from observation-well network, 2003-2004, Chester County, Pennsylvania.

\begin{tabular}{|c|c|c|c|c|c|c|c|c|c|c|c|c|c|}
\hline $\begin{array}{c}\text { U.S. } \\
\text { Geological } \\
\text { Survey }\end{array}$ & & & & & & Depth to wa & er, in feet, o & given date & & & & & \\
\hline \multirow[t]{2}{*}{ CH-1158 } & $04 / 10 / 03$ & $05 / 09 / 03$ & $06 / 10 / 03$ & $07 / 14 / 03$ & $08 / 11 / 03$ & 09/10/03 & $10 / 10 / 03$ & $11 / 10 / 03$ & $12 / 10 / 03$ & $01 / 13 / 04$ & $02 / 10 / 04$ & $03 / 12 / 04$ & $04 / 09 / 04$ \\
\hline & 9.86 & 10.54 & 9.38 & 10.25 & 11.14 & 11.65 & 10.67 & 9.55 & 9.85 & 10.17 & 9.99 & 10.62 & 10.19 \\
\hline \multirow[t]{2}{*}{ CH-5071 } & $04 / 10 / 03$ & $05 / 09 / 03$ & $06 / 10 / 03$ & $07 / 14 / 03$ & $08 / 11 / 03$ & 09/10/03 & $10 / 10 / 03$ & $11 / 10 / 03$ & $12 / 10 / 03$ & $01 / 13 / 04$ & $02 / 10 / 04$ & $03 / 12 / 04$ & $04 / 09 / 04$ \\
\hline & .92 & .93 & .11 & .87 & .89 & 1.00 & .87 & .86 & .94 & 1.50 & .92 & .94 & .95 \\
\hline \multirow{2}{*}{ CH-6519 } & $04 / 22 / 03$ & $05 / 20 / 03$ & $06 / 20 / 03$ & $07 / 22 / 03$ & 08/21/03 & 09/23/03 & $10 / 21 / 03$ & $11 / 10 / 03$ & $12 / 19 / 03$ & $01 / 21 / 04$ & $02 / 19 / 04$ & 03/19/04 & No Data \\
\hline & 59.38 & 60.98 & 54.66 & 54.60 & 52.02 & 41.55 & 44.19 & 44.19 & 42.25 & 47.42 & 47.80 & 48.96 & No Data \\
\hline \multirow[t]{2}{*}{ CH-6664 } & $04 / 10 / 03$ & $05 / 09 / 03$ & $06 / 10 / 03$ & $07 / 14 / 03$ & 08/11/03 & 09/10/03 & $10 / 10 / 03$ & $11 / 10 / 03$ & $12 / 10 / 03$ & $01 / 13 / 04$ & $02 / 10 / 04$ & $03 / 12 / 04$ & $04 / 09 / 04$ \\
\hline & 17.75 & 18.05 & 16.80 & 22.62 & 19.82 & 21.81 & 15.06 & 15.59 & 15.92 & 21.40 & 14.97 & 18.67 & 16.54 \\
\hline \multirow[t]{2}{*}{ CH-6665 } & 04/10/03 & 05/09/03 & 06/10/03 & $07 / 14 / 03$ & 08/11/03 & 09/10/03 & $10 / 10 / 03$ & 11/10/03 & $12 / 10 / 03$ & $01 / 13 / 04$ & 02/10/04 & $03 / 12 / 04$ & $04 / 09 / 04$ \\
\hline & 15.42 & 16.44 & 15.86 & 16.29 & 17.14 & 17.36 & 15.59 & 15.43 & 15.78 & 16.09 & 15.82 & 16.53 & 16.38 \\
\hline \multirow[t]{2}{*}{ CH-6666 } & $04 / 10 / 03$ & $05 / 09 / 03$ & 06/10/03 & $07 / 14 / 03$ & 08/11/03 & 09/10/03 & $10 / 10 / 03$ & $11 / 10 / 03$ & $12 / 10 / 03$ & $01 / 13 / 04$ & $02 / 10 / 04$ & $03 / 12 / 04$ & $04 / 09 / 04$ \\
\hline & 1.96 & 2.45 & 2.44 & 3.71 & 8.07 & 3.53 & 1.38 & 2.24 & 44.98 & 48.00 & 3.14 & 2.43 & 1.88 \\
\hline \multirow[t]{2}{*}{ CH-6667 } & $04 / 10 / 03$ & $05 / 09 / 03$ & $06 / 10 / 03$ & $07 / 14 / 03$ & 08/11/03 & 09/10/03 & 10/10/03 & 11/10/03 & $12 / 10 / 03$ & $01 / 13 / 04$ & 02/10/04 & $03 / 12 / 04$ & $04 / 09 / 04$ \\
\hline & 47.30 & 47.97 & 45.62 & 44.36 & 46.21 & 45.33 & 41.51 & 40.97 & 40.74 & 39.99 & 40.83 & 41.90 & 42.60 \\
\hline \multirow[t]{2}{*}{ CH-6668 } & $04 / 10 / 03$ & $05 / 09 / 03$ & 06/10/03 & $07 / 14 / 03$ & 08/11/03 & 09/10/03 & $10 / 21 / 03$ & $11 / 10 / 03$ & $12 / 10 / 03$ & $01 / 13 / 04$ & $02 / 10 / 04$ & $03 / 12 / 04$ & 04/09/04 \\
\hline & 62.25 & 63.35 & 58.75 & 58.52 & 60.41 & 58.45 & 55.82 & 53.94 & 53.78 & 52.78 & 53.58 & 54.81 & 55.5 \\
\hline \multirow[t]{2}{*}{ CH-6669 } & $04 / 10 / 03$ & $05 / 09 / 03$ & $06 / 10 / 03$ & $07 / 14 / 03$ & 08/11/03 & 09/10/03 & $10 / 10 / 03$ & $11 / 10 / 03$ & $12 / 10 / 03$ & $01 / 13 / 04$ & 02/10/04 & $03 / 12 / 04$ & $04 / 09 / 04$ \\
\hline & 32.00 & 35.36 & 19.75 & 46.76 & 21.56 & 32.22 & 24.29 & 23.82 & 23.41 & 30.85 & 25.82 & 24.86 & 28.97 \\
\hline \multirow[t]{2}{*}{ CH-6670 } & $04 / 10 / 03$ & $05 / 09 / 03$ & 06/10/03 & $07 / 14 / 03$ & 08/11/03 & 09/10/03 & $10 / 10 / 03$ & $11 / 10 / 03$ & $12 / 10 / 03$ & $01 / 13 / 04$ & $02 / 10 / 04$ & $03 / 12 / 04$ & $04 / 09 / 04$ \\
\hline & 22.92 & 23.36 & 19.98 & 23.29 & 23.37 & 23.44 & 22.68 & 21.27 & 22.36 & 22.84 & 21.83 & 23.35 & 22.81 \\
\hline \multirow[t]{2}{*}{ CH-6671 } & $04 / 10 / 03$ & 05/09/03 & $06 / 10 / 03$ & $07 / 14 / 03$ & 08/11/03 & 09/10/03 & $10 / 10 / 03$ & $11 / 10 / 03$ & $12 / 10 / 03$ & $01 / 13 / 04$ & 02/10/04 & 03/12/04 & 04/09/04 \\
\hline & 59.53 & 61.03 & 54.89 & 59.77 & 63.37 & 65.19 & 58.33 & 56.10 & 57.83 & 58.89 & 58.87 & 62.37 & 58.53 \\
\hline \multirow[t]{2}{*}{ CH-6672 } & $04 / 10 / 03$ & $05 / 09 / 03$ & $06 / 10 / 03$ & $07 / 14 / 03$ & 08/11/03 & 09/10/03 & $10 / 10 / 03$ & $11 / 10 / 03$ & $12 / 10 / 03$ & $01 / 13 / 04$ & $02 / 10 / 04$ & $03 / 12 / 04$ & $04 / 09 / 04$ \\
\hline & 79.81 & 82.38 & 75.09 & 80.80 & 83.58 & 86.32 & 80.00 & 77.58 & 79.37 & 80.42 & 77.30 & 83.41 & 80.29 \\
\hline \multirow[t]{2}{*}{ CH-6673 } & $04 / 10 / 03$ & $05 / 09 / 03$ & 06/10/03 & $07 / 14 / 03$ & 08/11/03 & 09/10/03 & $10 / 10 / 03$ & $11 / 10 / 03$ & $12 / 10 / 03$ & $01 / 13 / 04$ & $02 / 10 / 04$ & $03 / 12 / 04$ & 04/09/04 \\
\hline & 29.40 & 20.87 & 18.77 & 34.70 & 30.46 & 29.37 & 29.19 & 25.63 & 23.86 & 28.22 & 26.73 & 50.65 & 32.75 \\
\hline \multirow[t]{2}{*}{ CH-6674 } & $04 / 10 / 03$ & $05 / 09 / 03$ & $06 / 10 / 03$ & $07 / 14 / 03$ & 08/11/03 & 09/10/03 & $10 / 10 / 03$ & $11 / 10 / 03$ & $12 / 10 / 03$ & $01 / 13 / 04$ & $02 / 10 / 04$ & $03 / 12 / 04$ & $04 / 09 / 04$ \\
\hline & 32.72 & 33.00 & 33.05 & 31.12 & 32.39 & 33.14 & 31.05 & 31.56 & 31.91 & 31.76 & 32.93 & 33.92 & 34.19 \\
\hline
\end{tabular}

